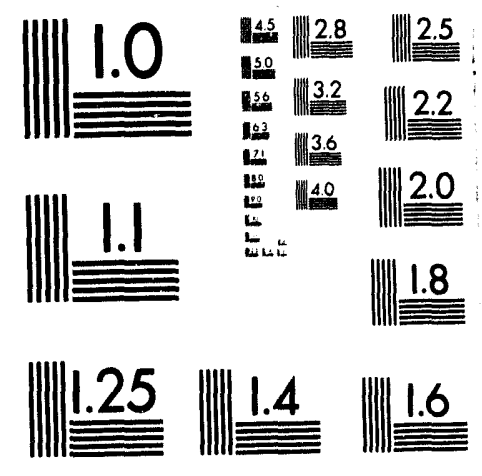



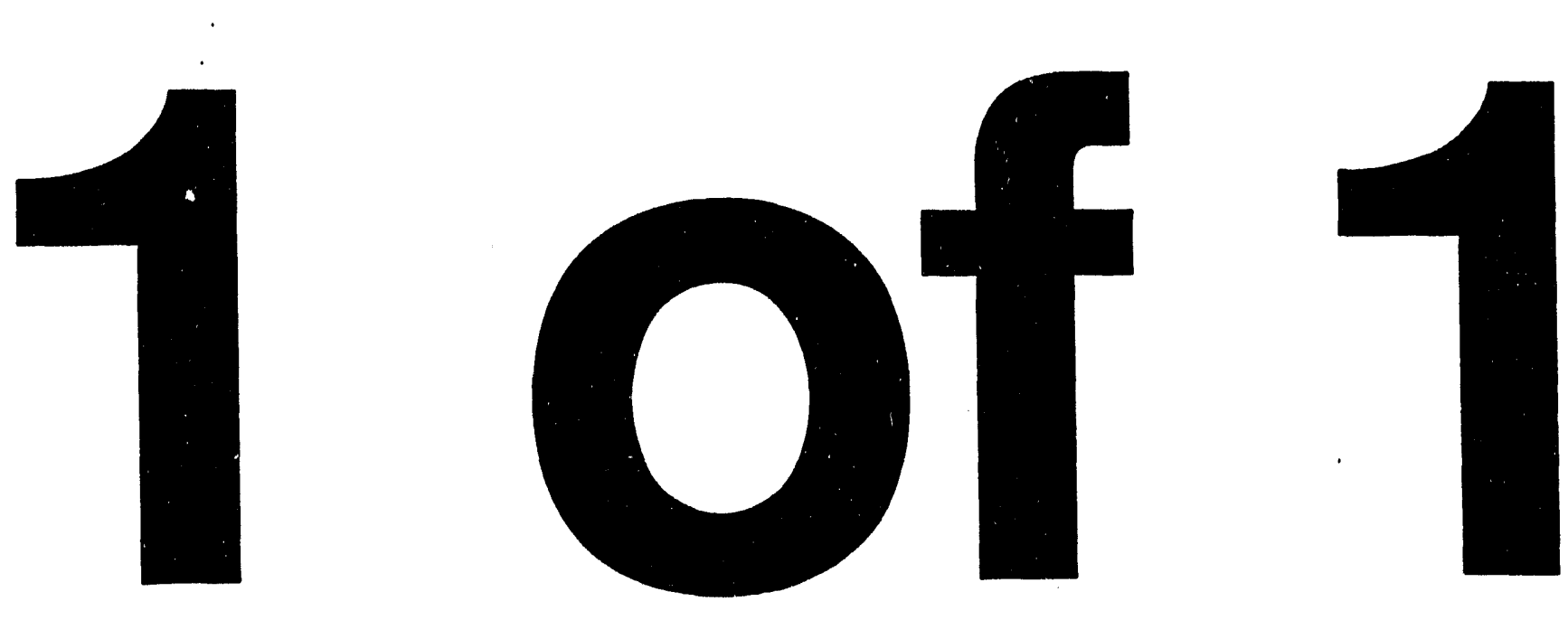


\section{Multiple Missions: The 300 Area in Hanford Site History}

M. S. Gerber, PhD

Date Published

September 1993

Prepared for the U.S. Department of Energy Office of Environmental Restoration and Waste Management

\section{(2) Westinghouse P.O. Box 1970}

(W) Hanford Company Richland, Washington 99352

Hanford Operations and Engineering Contractor for the

U.S. Department of Energy under Contract DE-AC06-87RL10930

Approved for Public Release 


\section{RELEASE AUTHORIZATION}

Document Number: WHC-MR-0440

Document Title: Multiple Missions:

The 300 Area in Hanford Site History

Release Date: $\quad$ September 30, 1993

$* * * * * * * * * * * * *$

This document was reviewed following the procedures described in WHC-CM-3-4 and is:

\section{APPROVED FOR PUBLIC RELEASE}

$* * * * * * * * * * * * *$

Information Release Administration Specialist: M.N. Boston

M. Bostar

$9 / 30 / 93$

(Signature)

(Date) 


\section{WHC-MR-0440}

\section{CONTENTS}

Early Fuel Fabrication at the Hanford Site

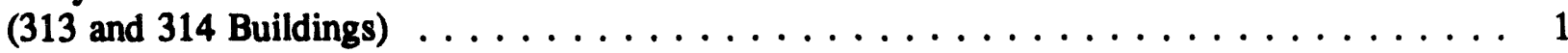

$\mathbf{N}$ Reactor Fuel Fabrication in the 300 Area $\ldots \ldots \ldots \ldots \ldots \ldots$

305 Test Pile Was Hanford's First

Operating Reactor $\ldots \ldots \ldots \ldots \ldots \ldots \ldots \ldots \ldots \ldots \ldots \ldots \ldots \ldots$

Early "Process Improvement" Chemical Research at the

Hanford Site $(321$ and 3706 Buildings) $\ldots \ldots \ldots \ldots \ldots \ldots$

Major 1952 and 1953 Expansions in the 300 Area (325 and 329 Buildings) . . . . . . . . . 21

Early 300 Area Facilities Constructed to Support

Reactor Development (326 and 327 Buildings) $\ldots \ldots \ldots \ldots \ldots$. . . . . . . . . . 27

Hanford Site Ventures With the "Peaceful Atom":

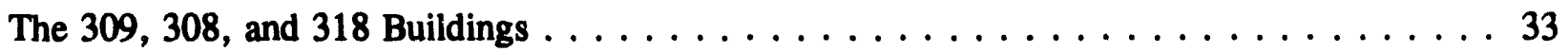

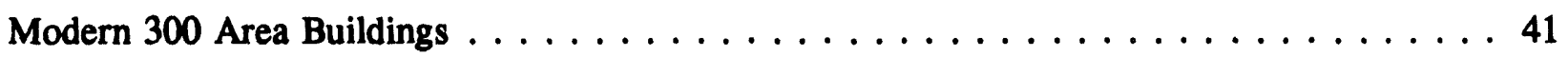

Significant Miscellaneous Buildings in the 300 Area . . . . . . . . . . . . . 47

300 Area Process Waste Handling and Disposal $\ldots \ldots \ldots \ldots \ldots$

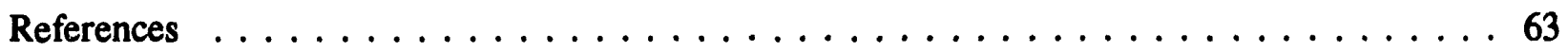




\section{LIST OF TERMS}

\begin{tabular}{|c|c|}
\hline AEC & U.S. Atomic Energy Commission \\
\hline CWS & Chemical Warfare Service \\
\hline DE & destructive examination \\
\hline duPont & E. I. duPont de Nemours and Company \\
\hline EBR-II & Experimental Breeder Reactor II \\
\hline EDL & Engineering Development Laboratory \\
\hline FFTF & Fast Flux Test Facility \\
\hline FMEF & Fuels and Materials Examination Facility \\
\hline FMPC & Feed Materials Production Center \\
\hline HCRL & Hanford Cultural Resources Laboratory \\
\hline HCVF & Hot Cell Verification Facility \\
\hline HEPA & high-efficiency particulate air (filter) \\
\hline HEW & Hanford Engineer Works \\
\hline HLO & Hanford Laboratories Operation \\
\hline HTLTR & High-Temperature Lattice Test Reactor \\
\hline HTSF & High-Temperature Sodium Facility \\
\hline HW & Hanford Works \\
\hline I\&E & internally and externally (conled) \\
\hline MED & Manhattan Engineer District \\
\hline MTR & Materials Test Reactor \\
\hline NDE & nondestructive examination \\
\hline PCBs & polychlorinated biphenyls \\
\hline PFMP & PUREX Facility Modification Program \\
\hline PFPP & Plutonium Fabrication Pilot Plant \\
\hline PRCF & Plutonium Recycle Critical Facility \\
\hline PRTR & Plutonium Recycle Test Reactor \\
\hline PUREX & Plutonium/Uranium Extraction (Plant) \\
\hline PVC & polyvinyl chloride \\
\hline QA & quality assurance \\
\hline RECUPLEX & reclamation of uranium and plutonium by extraction (process) \\
\hline REDOX & reduction oxidation (process) \\
\hline RLWS & Radioactive Liquid Waste System \\
\hline SAF & Secured Automated Fabrication (facility) \\
\hline SERF & Special Environmental Radiometallurgical Facility \\
\hline SMF & Shielded Materials Facility \\
\hline TD & thoria dispersed \\
\hline TRIGA & Training Research Isotopes, General Atomics (reactor) \\
\hline UNH & uranyl nitrate hexahydrate \\
\hline WATS & Waste Acid Treatment System \\
\hline WSEP & Waste Solidification Engineering Project \\
\hline
\end{tabular}




\section{Early Fuel Fabrication at the Hanford Site (313 and 314 Buildings)}

\section{The Feel of History}

Walk into the cavernous 490 -foot-long 313 Metal Fabrication Building, now being readied for shutdown, and you will feel the history all around you. Look at the old tan and beige walls and the squat 1950s tanks and filter press in the south end, which contrast so sharply with the bright blue Hanford Metalworking Facility equipment installed in the north end only five years ago.

This structure, along with the nearby 314 Press Building, housed the uranium fuel fabrication processes for the first full-scale plutonium production process in world history. The mission of the 313 Building was to machine bare uranium rods to desired dimensions for use in Hanford's reactors, jacket ("can") the sized fuel elements, and test the jackets for proper bonding and sealing. The 314 Building contained equipment to extrude raw uranium billets into rods and then straighten and outgas them. Autoclaves that performed a final test on the jacketed elements also were located in the 314 Building.

\section{Evolution of World War II Fuel Fabrication Techniques Not Easy}

Both facilities were constructed during World War II by the Manhattan Engineer District (MED) and E.I. duPont de Nemours and Company (duPont). In the autumn of 1943, the 313 Building was completed in a rectangular shape with overall dimensions of
199.5 feet by 65 feet by 20 feet (high). However, eight additions were constructed in just the next 10 months, nearly tripling the width of the building to 182.5 feet! The continual early additions were caused by process improvements and changes in the very new, untried, and unique uranium fuel fabrication activities being carried out in the facility. According to duPont: "In the construction of the 313 Building...innumerable changes were made." (Ref. 2, p. 997) After an initial electric heater press (termed the "whiz-bang" by Hanford workers) failed to produce properly bonded fuel jackets, a "triple-dip" method was perfected in mid1944.

In the 314 Building, autoclaves for fuel element testing started to operate in July 1944, and outgassing and straightening operations commenced there in September 1944. In January 1945, a large extrusion press began to operate in the 314 Building, and from that time until 1948 a complete cycle of metal preparation operated at the Hanford Engineer Works (HEW). The uranium biliets went first to the 314 Building for extrusion, outgassing, and straightening, then to the 313 Building for machining, canning, and initial inspection, and then back to the 314 Building for autoclave and radiograph testing. 


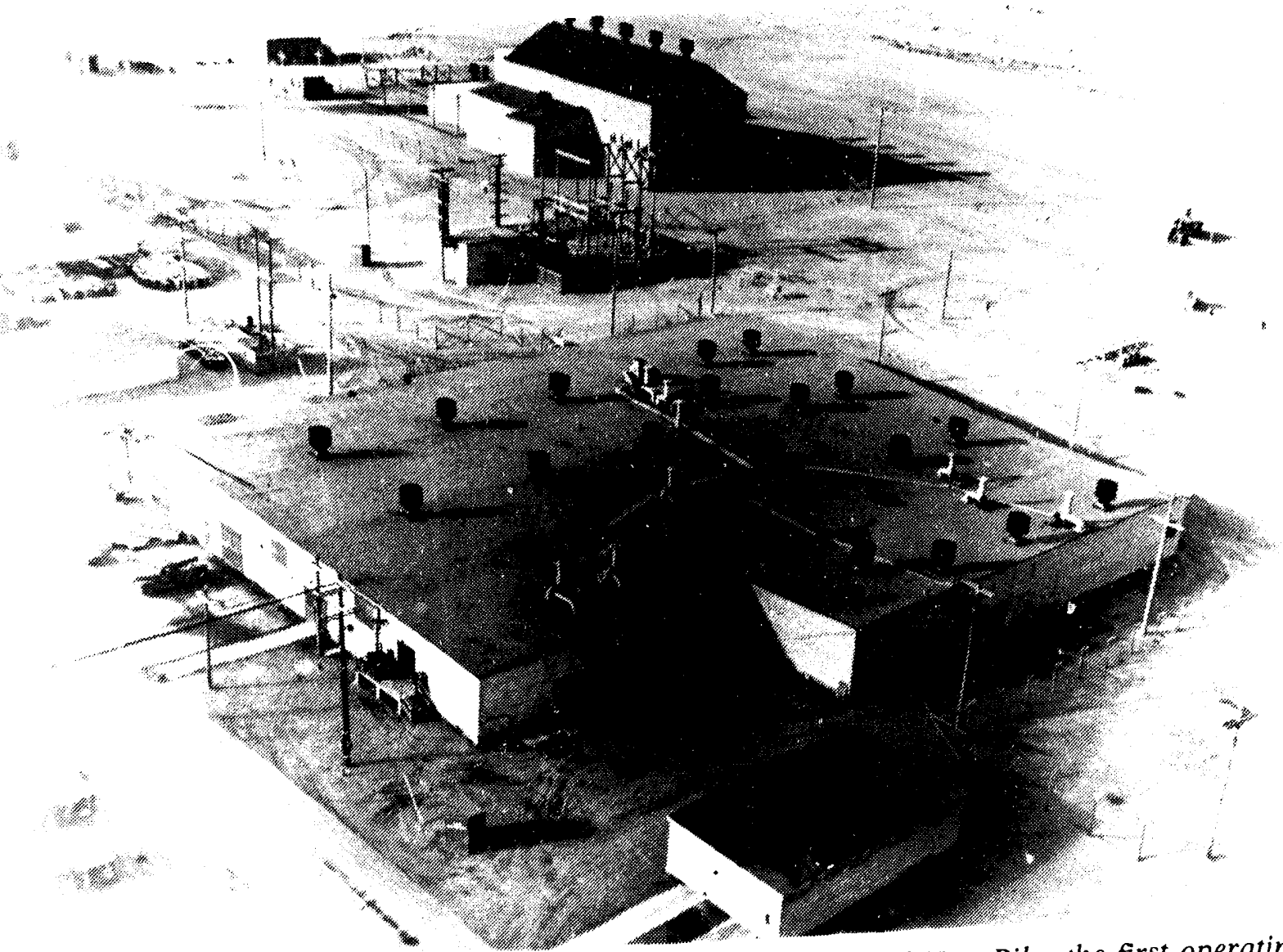

Fabrication Building as it stood in 1945. (The 305 Test Pile, the first operating The 313 Metal Fabricantiongeer Works, casts a mid-afternoon shadow near the top of the photo.)

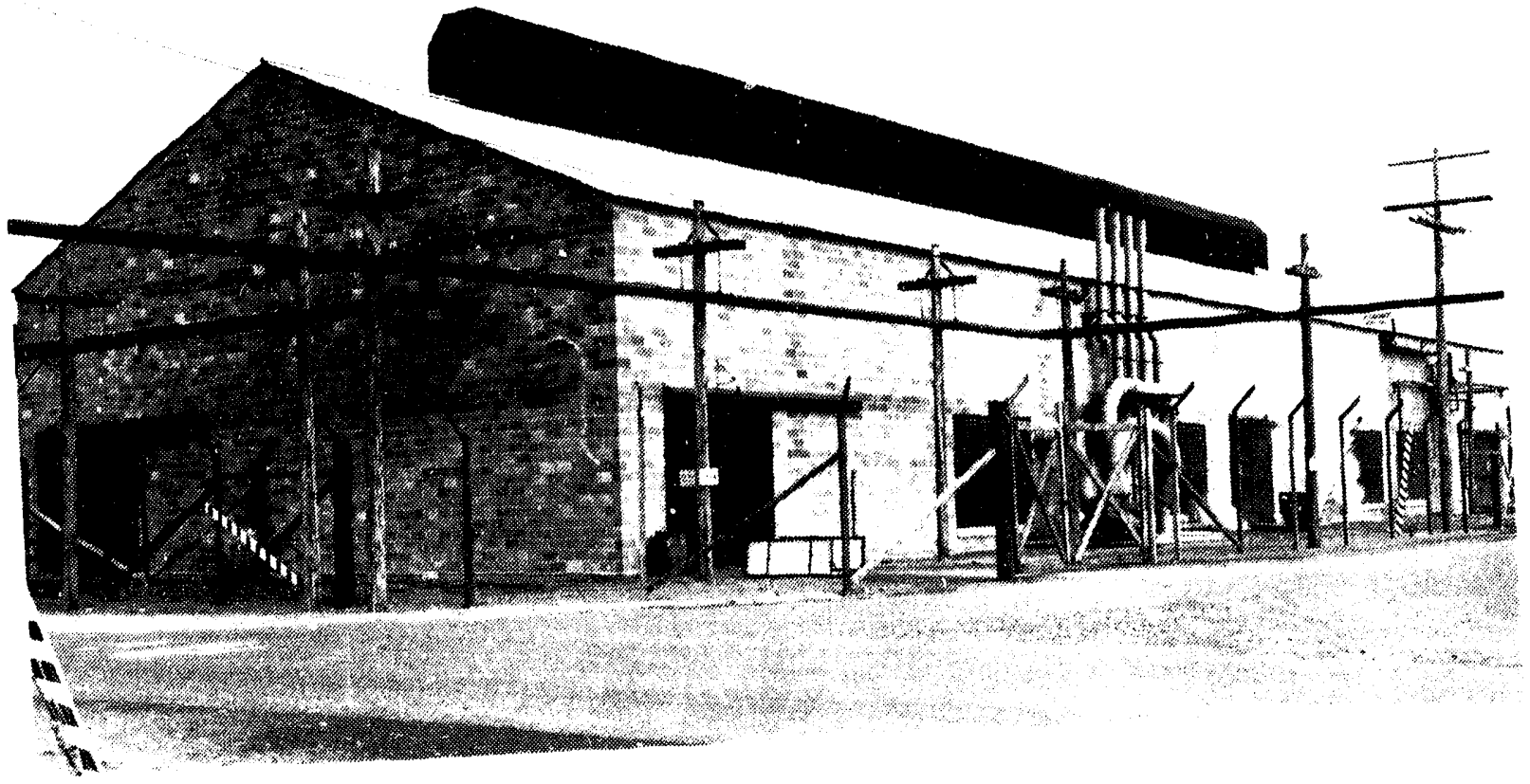

The 314 Press Buildiitg as it stood new in February 1945. 


\section{Triple-Dip}

The triple-dip fuel jacieting method, used successfully in World War II, consisted of cleaning bare uranium cores in nitric acid and then bathing them in succession in molten bronze, tin, and an aluminum silicon mixture. Steel "sleeves" that surrounded each can were first cleaned in sodium hydroxide, and aluminum caps and cans were cleaned in a sodium dichromate solution followed by a methanol dip and air drying. After the three dips and water quenching, the sleeve was pulled away from the fuel element, the aluminum end cap was machined and stamped with an identification number, and the braze line on the end cap was tungsten-inert-gas welded to seal the porous braze to the end cap and can. A final etching in nitric acid completed the procedures.

Three tests followed the triple-dip canning process. The first, the frost test, consisted of spraying the can with acenaphthene mixed with carbon tetrachloride. The canned element was then placed into an induction coil to heat its surface. If there was a gas bubble or a nonbonded spot, the acenaphthene would melt, and that spot would become shiny. The element then would be rejected and sent back through a recycling process. If the bond was good, the acenaphthene then was removed with trichloroethylene, and the canned element was placed into a steam autoclave to see if any pinholes or incomplete welds existed. Water from the steam would be conducted in through any such openings, and the uranium core would react with water to form uranium oxides that would expand rapidly and split the aluminum can. If an element passed the autoclave test, it then underwent a final radiograph test in the 314 Building to detect porosity in the end weld bead. Any porosity could become a pathway for water to contact the uranium fuel during irradiation and cause the element to rupture.

\section{Post-World War II Changes}

In 1948 the extrusion press in the 314 Building was sold, and Hanford Works (HW), the name given to the Hanford Site in 1947 by the U.S. Atomic Energy Commission (AEC), began to receive rolled uranium rods from an offsite commercial mill. The rolling process seemed to offer metallurgical advantages, in that the uranium could be processed at lower temperatures, thus producing smaller and more random grains within the metal and avoiding the "pimpling and dimpling " of fuel elements, a persistent problem in early fabrication efforts. It was also a less expensive process. In 1950 and 1951 , a rolling mill was installed in the 314 Building, but in 1952 the rolling operation was transferred to a large facility constructed at the Feed Materials Production Center (FMPC), an AEC site in Fernald, Ohio.

In 1954, the 313 Building underwent a major remodeling and expansion that more than doubled its size, and fuel canning technology at HW switched to a new lead-dip process. This process consisted of immersing the uranium fuel cores in a duplex bath (molten lead covered with molten aluminum silicon), followed by a molten aluminum silicon bath. This process allowed the first canning bath to occur at a lower temperature because the uranium cores had been beta heat treated in a molten salt bath at the FMPC. The new method, however, introduced a great deal more lead and other heavy metals into 313 Building waste streams because approximately 30,000 fuel elements were being canned each week during the years of peak single-pass reactor operations at HW (1955 to 1964). At about the same time that the lead-dip process replaced the triple-dip method, an ultrasonic test replaced the frost test, thus eliminating the use of acenaphthene and carbon tetrachloride. 


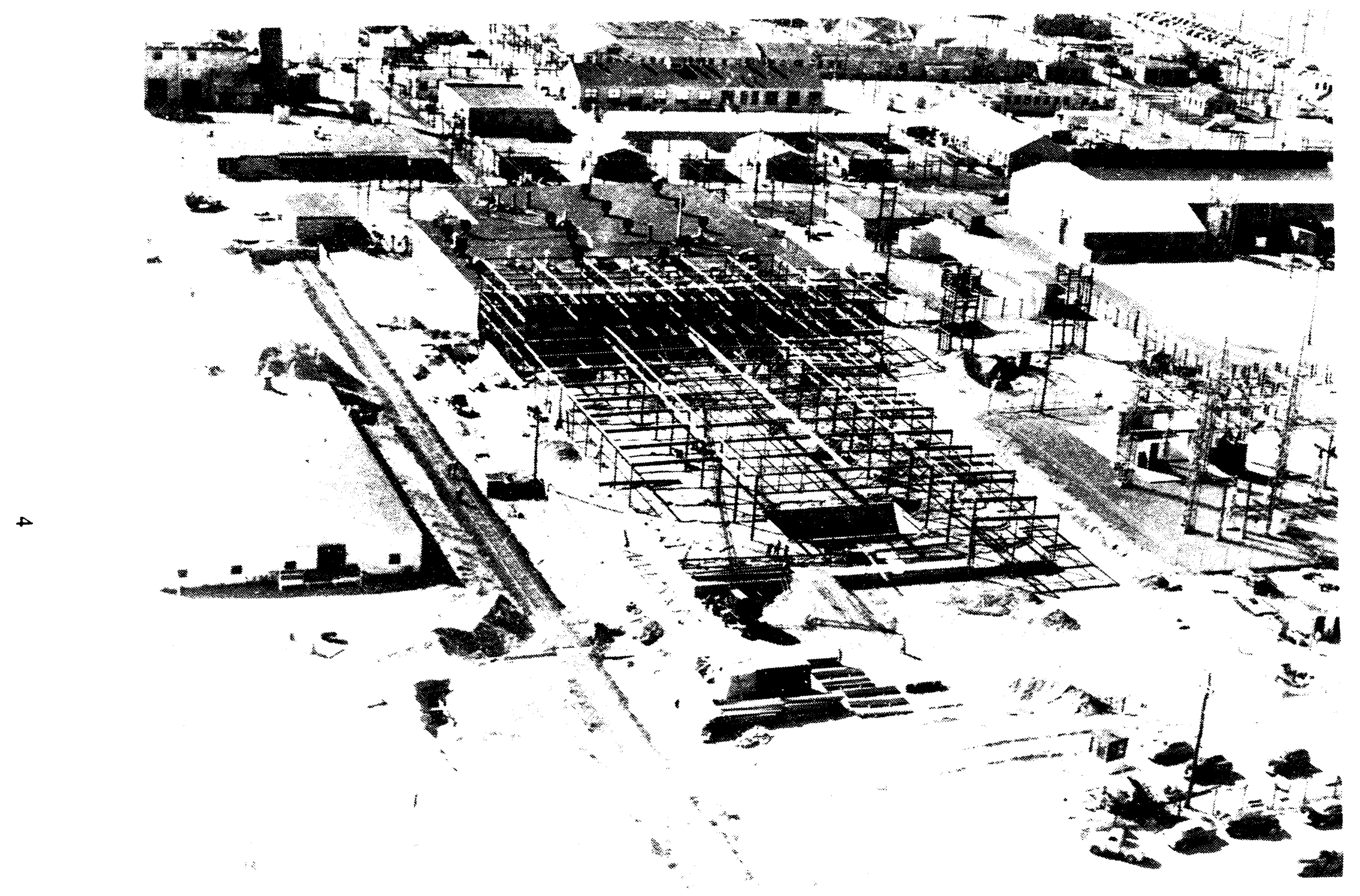

The 313 Metal Fubricution Building during its 1954 addition. The new construction on the north end extended the structure from 260 feet to 490 fe't in length. 


\section{Cored, Internally and Externally Cooled, and Projection Fuel Elements}

Additional fuel fabrication process changes during the 1950s and early 1960 s in the 313 Building included the manufacture of cored fuel rods beginning in 1954, internally and externally cooled (I $?$,E) fuel elements beginning in 1957, and projection fuel rods in the early $1960 \mathrm{~s}$. The cored rods, holivw elements with an aluminum plug at either end bonded to the uranium with an aluminum silicon braze, were designed to give the uranium an inner space in which to expand during irradiation. The early, solid fuel elements were experiencing a troublesome level of distortion and subsequent rupture in HW's production reactors. However, the cored fuel elements frequently developed cracks in the uranium at the aluminum plug, and they were discontinued in 1957. The I\&E fuel elements had a tubular hole down the middle, allowing cooling water to run both around and through them in the reactors. Projection fuel eiements also allowed better circulation of cooling water between the elements and the reactor process tube walls.

\section{Other Processes in 1950s and 1960s Fuel Fabrication}

Other fuel fabrication activities carried out in the 313 and 314 Buildings included the manufacture of lithium aluminum fuel targets and enriched uranium aluminum driver elements for tritium extraction (1949 to 1952). Additionally, bismuth fuel targets were manufactured and welded into nonbonded aluminum cans and irradiated to make polonium-210 in 100 Areas production reactors from 1944 through the early 1950s. Polonium-210 was the initiator in atomic weapons explosions. An even larger number of lead cadmium fuel elements, also welded into nonbonded aluminum cans, were produced for use as "poison" elements in the 100 Areas reactors and in the 305 Test Pile. The term poison refers to the ability of these neutron absorbing metals to slow down or even kill (control) nuclear chain reactions. The production of lead cadmium fuel rods continued until 1971, when single-pass reactor operations ended at HW.

Additionally, beginning in the late 1950 s and continuing until 1971 , a process to electrolytically anodize the aluminum spacers used in the single-pass reactors (to create a protective aluminum oxide coating) was added in the 313 Building. Also, enriched uranium aluminum fuel cores, used as driver elements in a uranium-233 production program, were manufactured in the building in the mid-1960s. Beginning in the mid-1960s, many activities in support of $\mathbf{N}$ Reactor operations also took place there, including the passivation of steel spacers to reduce rust formation and quality assurance (QA) inspections of the Zircaloy-2 material and the beryllium Zircaloy-2 braze rings from which $\mathbf{N}$ Reactor fuel element cladding was made.

In the early 1960 s, just before the eight single-pass reactors at HW began to close, experiments took place in the 313 Building and other Hanford facilities to develop a new canning procedure known as the Hot Die Size process. Also termed the "nickel-plate" procedure, this operation plated uranium fuel cores with nickel, using nickel sulfate, nickel chloride, and boric acid. Although the Hot Die Size method was tested successfully, it was not implemented on a large scale because of the closure of Hanford's single-pass reactors. All fuel element preparation activities for the single-pass reactors ceased in the 313 and 314 Buildings in 1971, and the fabrication equipment was removed between the mid-1970s and the mid-1980s. 


\section{WHC-MR-0440}

This page intentionally left blank. 


\section{N Reactor Fuel Fabrication in the 300 Area}

\section{Coextrusion Process Unique}

The unique new process for jacketing or cladding uranium fuel elements for Hanford's $\mathrm{N}$ Reactor was initially developed in the 306 Fuel Element Pilot Plant. Also known as the "Met Semi-Works," this building was first completed in 1956 to support 313 Building operations and to pilot process improvements in single-pass reactor fuel fabrication methods. In 1960 the 306 Building was expanded to approximately double its original size to develop the coextrusion fabrication process for $\mathrm{N}$ Reactor fuel elements. Also in 1960, just three years before $\mathrm{N}$ Reactor became operational, the 333 Fuels Manufacturing Building was completed. Then termed the New Fuel Cladding Facility, its mission was to manufacture fuel elements for the $\mathbf{N}$ Reactor using the new process.

The coextrusion process fundamentally altered the way that fuel elements had been made at Hanford since World War II. Essentially, all of the fuel-element components, including the uranium core and all of the cladding materials, were cleaned, assembled, and then extruded together. This method provided a better, more uniform bond than had the earlier processes of jacketing each fuel element separately. The $\mathbf{N}$ Reactor fuel elements had a tube-in-tube configuration (with a hole running down the entire length of the element). Each assembled element was 26 inches long and weighed approximately 52 pounds. The coextrusion process was beneficial in smoothly cladding the inner and outer tubes so that they would fit together without developing "hot spots."

In the coextrusion process, the copper and copper silicon preshapes and backing plates used in the process first were inspected and cleaned with nitric, nitric hydrofluoric, and chromic nitric sulfuric acid. Next, cladding components from a specific alloy known as Zircaloy-2, consisting mainly of zirconium combined with small amounts of tin, nickel, iron, and chromium, were degreased, rinsed in nitric and hydrofluoric acid, and forced-air dried. In the meantime, uranium billets were degreased with perchloroethylene, etched with nitric acid, rinsed, dried, and inspected.

Next, the copper, copper silicon, Zircaloy-2, and uranium components were assembled and welded into a billet assembly. This assembly was evacuated of air, leak tested, sealed, preheated, and then coextruded (squeezed together) in an extrusion press. As the process specifications for this step emphasized: "The quality of the extruded tube is dependent upon many things, not the least of which is skill, care, effort, and precision that are put into the co-extrusion operation." (Ref. 3, p. 1)

This process was repeated for both the outer (larger) and inner (smaller) tubes that made up the tube-in-tube configuration. The extruded tubes then exited the press to a rollout table where they were rolled continuously for at least six minutes to prevent tube deformation and nonuniform cooling. They then were sectioned to the specified length, and the ends were machined to create fuel sections or elements. Nitric acid was used to remove copper silicon residues, and nitric sulfuric acid was used to chemically mill (i.e., dissolve away) excess uranium on fuel element ends. Elements then were etched with nitric hydrofluoric and nitric acid and brazed 
with an etched braze ring material consisting of Zircaloy-2 alloyed with about 5\% beryllium. (This braze material previously had been degreased and etched.) The brazed elements were heat treated in a molten salt bath to randomize the uranium grain structure to prevent preferential grain growth that could rupture the elements in the reactor.

The next step in the process was to weld projections or supports onto the fuel elements. The N Reactor, having benefitted from nearly two decades of experience with Hanford's eight older reactors, used only projection fuel elements and smooth-bore process tubes. Eight lengthwise protrusions were attached to the outer surface of each fuel element, evenly spaced around its diameter. This configuration allowed cooling water to circulate optimally around the elements, without creating hot spots where the sides of elements rested too close to the inner walls of the process tubes. In the older Hanford reactors, all built with "ribbed" process tubes, the ribs on the inner tube walls often wore down after long periods of use, thus reducing circulation and causing hot spots that sometimes led to fuel element ruptures.

After projections were welded onto the $\mathrm{N}$ Reactor fuel elements, the two tubes (inner and outer) had to be attached together. Support hardware was attached to the outer surface of the inner tube, and locking hardware was affixed to the inner surface of the outer tube. The two tubes then were given a final nitric hydrofluoric acid etch, autoclave tested, inspected, assembled and inter'ocked, and stored as finished fuel. The coextrusion process was carried out in the 333 Building continuously until December 1986 , reaching a peak volume of approximately 250 finished fuel elements each week in the mid-1980s.

\section{Other Processes in the 333 Building}

From 1965 to 1967 , special lithium aluminate inner fuel targets used to make N Reactor's "coproduct" (tritium) were fabricated in another 300 Area building but then autoclave tested, etched with nitric hydrofluoric acid, inspected, and assembled in an outer driver fuel element in the 333 Building. The outer portions of the enriched (2.1\% uranium-235) uranium driver fuel elements themselves were made in the 333 Building during those years. Between 1987 and 1989 , this building received upgrades and modifications in preparation for fabrication of new tritium driver fuel elements for N Reactor, but the February 1988 notification that $\mathbf{N}$ Reactor would be placed on "cold standby" precluded implementation of this program.

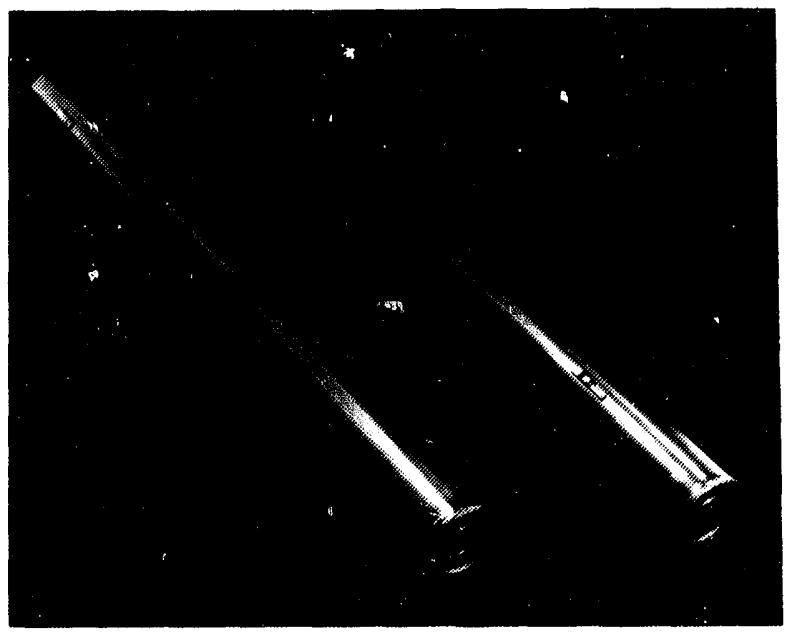

Left, a normal uranium fuel rod, manufactured using the coextrusion process, ready for insertion into $N$ Reactor. Right, an $N$ Reactor fuel element holding a lithium aluminate target used for making the "coproduct" (tritium), in the late 1960s. 


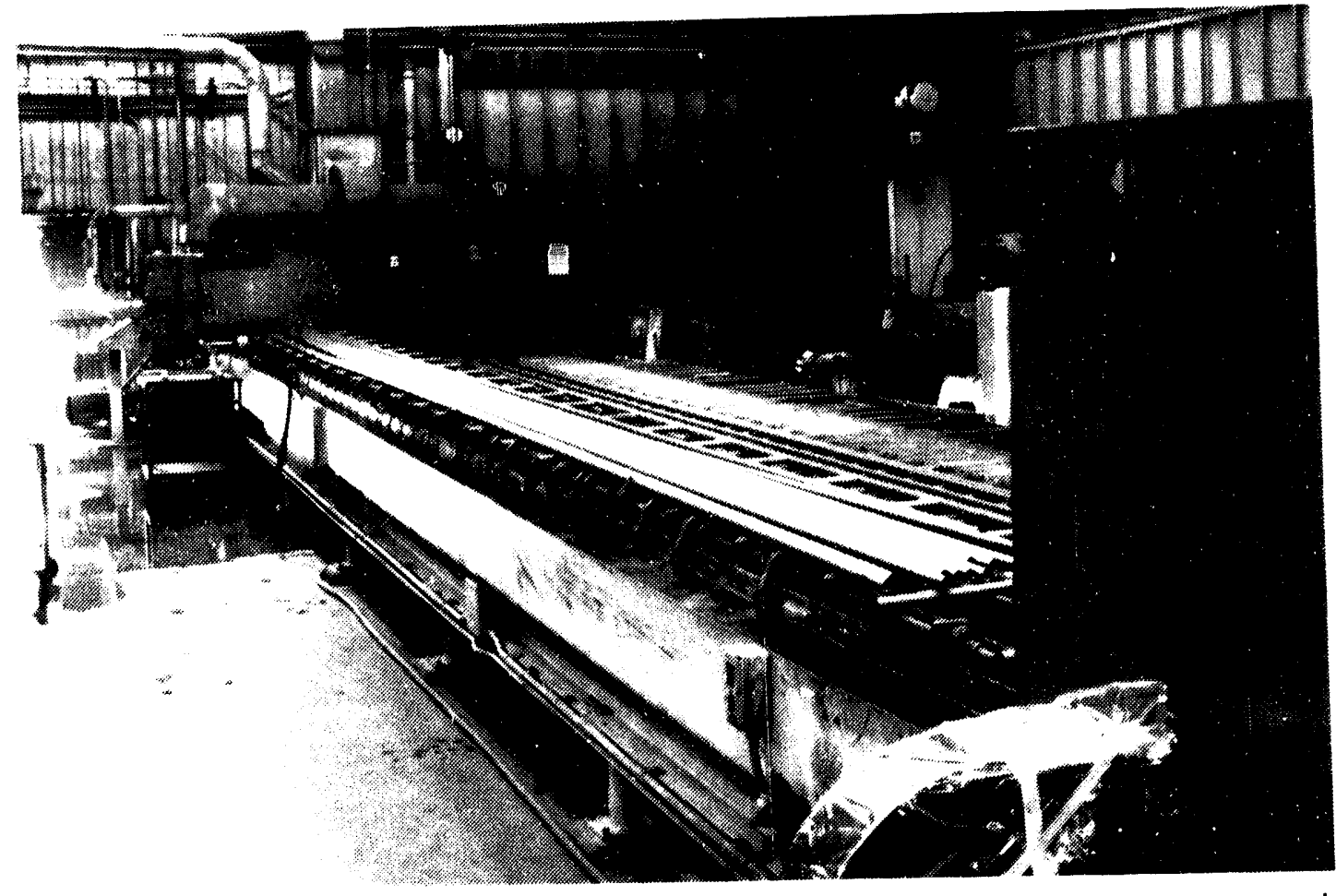

Uranium fuel rods coated with Zircaloy-2 leave the extrusion press on the run-out lable in the 3.33 Fuels Manufacturing Building and head for the cutoff saw in the early 1970s.

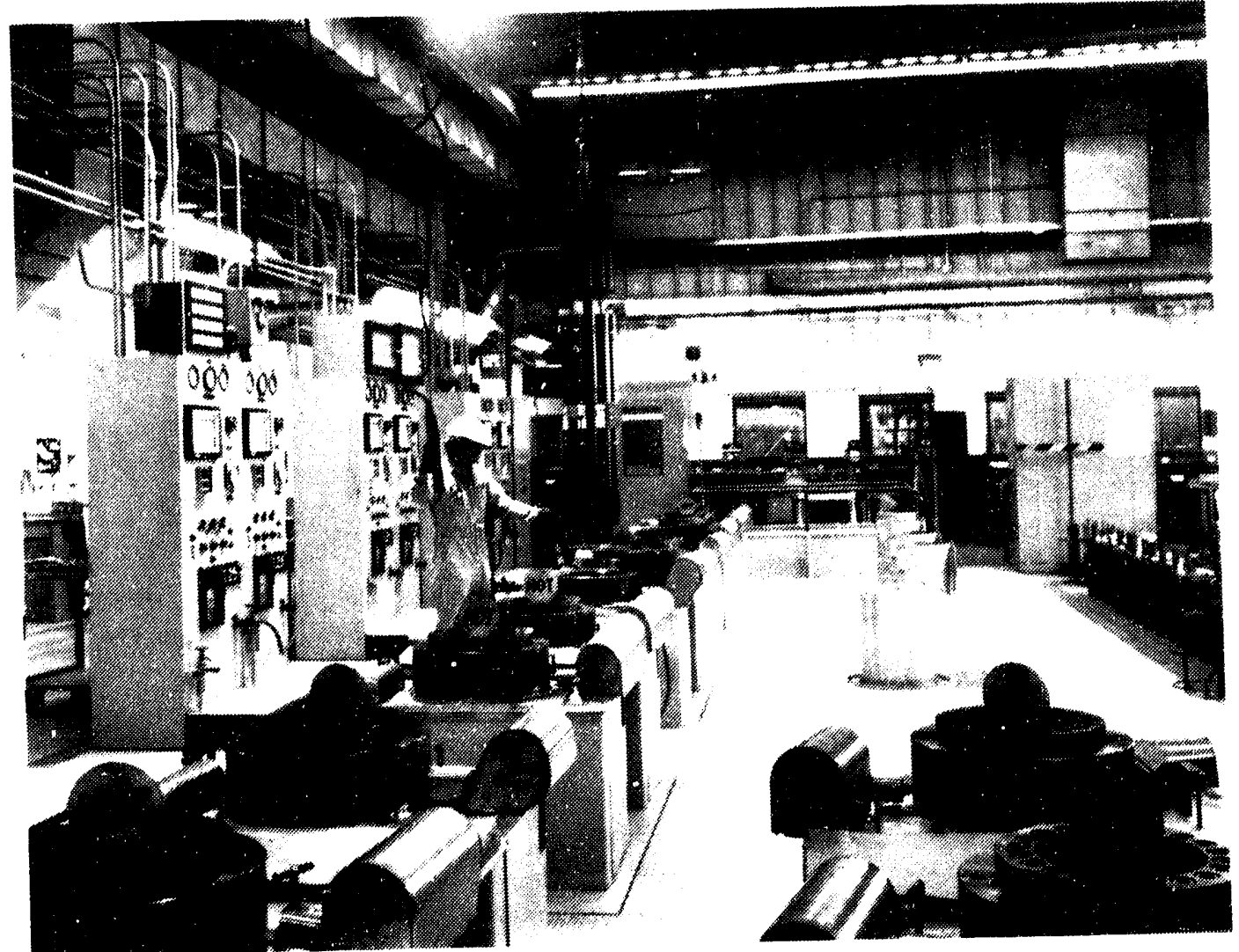

The autoclave inspertion area in the 33.3 Fuels Manufacturing Building. 1984. 


\section{Special Waste Treatment System Instituted in Mid-1970s}

Waste acids generated in 333 Building operations included nitric, sulfuric, hydrofluoric, and chromic nitric sulfuric acids bearing uranium, Zircaloy-2 components, copper, beryllium, and other fuel fabrication materials. Before 1973, acids containing nonrecoverable amounts of uranium were discharged first to a 3,800-gallon underground tank containing limestone, located east of the 333 Building. The waste acids then entered the 300 Area process sewer, where they percolated through ponds into nearby soils and into the Columbia River. In 1973, a Waste Acid Treatment System (WATS) began operating to treat waste acids from 333 Building operations. The WATS represented a method to prevent these fuel fabrication bulk waste acids from discharging to the 300 Area process sewer and provided a means to separate, treat, and find alternate disposal methods for them. (Waste acids containing recoverable amounts of uranium already were being treated for uranium recovery and were not treated as part of the WATS process.)

A small building (334-A) was emplaced over the site of the former limes.une neutralization pit just east of the 333 Building. The portion abovegrade was used for general storage of products and absorbents, and the portion belowgrade contained three tanks seated in a reinforced concrete pit 18.5 feet by 18.3 feet by 10 feet (deep). Waste acids were collected in the 334-A Building tanks and then pumped to the nearby 313 Building for neutralization with sodium hydroxide. The target $\mathrm{pH}$ after neutralization was between 10 and 12 . Waste acids containing nonrecoverable amounts of uranium were pumped to Tank 2 in the 313 Building for neutralization and, beginning in 1985 , were centrifuged to remove solids.

Solids from the centrifuge in the 313 Building were placed in drums and transferred to Hanford's Central Waste Complex for eventual disposal. Filter press effluent and centrifuge effluent from 313 Building operations then were pumped to other tanks for storage and transported by tanker truck to large, open basins in the deactivated $100-\mathrm{H}$ Reactor area for evaporation. However, the solar evaporation practice was stopped in 1985 when filter press and centrifuge effluents began to be taken to the 340 Retention and Neutralization Complex for transshipment to Hanford's 200 Areas or offsite for disposal.

During most of the years of WATS operation (1975 to 1988) the tanks in the 334-A Building received approximately 210,000 gallons of waste acids each year. In that period the primary chemical wastes from the 333 Building that continued to be discharged to the process sewer were rinse water, cooling water, and steam condensate. Occasionally over the years, acid spills and leaks also occurred, including a large one in June 1978, when a water fill line to a 333 Building process tank was left on for two days. Nearly 19,000 gallons of process water containing waste-etch acids with metals in solution overflowed the 334-A tanks containment basin at that time and entered the process sewer. Additionally, other smaller leaks have occurred. However, the polyvinyl chloride (PVC) transfer pipes of the WATS network are contained in covered concrete pipe trenches, and no significant known leaks have occurred from the pipes.

Today, a closure plan for the WATS facilities has been developed by the U.S. Department of Energy, Richland Operations Office, and the 333 Building is being cleaned and examined for alternate uses. 


\section{Test Pile Was Hanford's First Operating Reactor}

The 305 Test Pile (reactor), located in what was the northwesternmost corner of the 300 Area during World War II, was the first operating reactor at the Hanford Site.

According to duPont builders of the HEW, the wartime name for the Hanford Site, the 305 Test Pile was constructed as a QA tool to test samples of each lot of graphite, uranium, aluminum tubes, aluminum canning material (for fuel element jackets), and other materials used in the large HEW production reactors $(B$, D, and F Reactors). Measurements of the purity of materials, using instrumentation and calculations, were too time consuming for wartime schedules. Therefore, actual performance tests of material samples in a reactor were deemed necessary. Trials conducted in the 305 Test Pile compared the performance of material samples under irradiation with samples of known quality and graded each lot. According to duPont, the reactor also served as "a radiation source for technical and instrument development work." (Ref. 4, p. 151)

The 305 Reactor did operate critically but at a very low level, usually less than 50 watts. The average operating thermal level was 20 to $22{ }^{\circ} \mathrm{C}$. The reactor sat aboveground, inside a five-foot-thick concrete shielding barrier. The barrier could be opened on the south side for charging and discharging operations and for maintenance. After each assembly (or charging), a south barricade and a roof barricade made from concrete blocks were emplaced.

The pile's core was a 16-foot graphite cube with 1-foot graphite reflectors on all sides, giving it the overall dimensions of an 18-foot cube. The core was pierced by 519 circular holes and 20 rectangular holes. There were 292 metal-bearing channels with 8.5-inch lattice spacing. The reactor was natural uranium fueled and air cooled.

One solid vertical, boron-steel safety rod hung above the pile, which could be dropped into poison or tamp down reactivity. Additionally, a smaller metal safety rod on top of the pile could lower tiny boron-steel pellets or shot down another hole in the reactor. Three solid boron-steel horizontal control rods also could be inserted into the pile from the south side. These rods operated as emergency safety controls. However, the normal operating control rods, used to adjust reactivity in the pile, consisted of one mild steel shim rod and one cadmium-mild steel strip control rod, each 200 inches long. Automatic meters could be set to release the safety rods and drive the control rod into the pile at any desired power level.

\section{Test Pile Operations}

Sample materials were loaded and unloaded from the 305 Test Pile via metal stringers that fit the rectangular holes in the core. Uranium-bearing stringers (known as metal stringers) and graphite stringers ran from east to west through the reactor. Because of this configuration, materials were said to rest in the east stringers or the west stringers. Each stringer totalled about 500 inches in length, including the central test bed portions, end portions, and maple "pushers" that moved the devices in and out of each side of the reactor. 


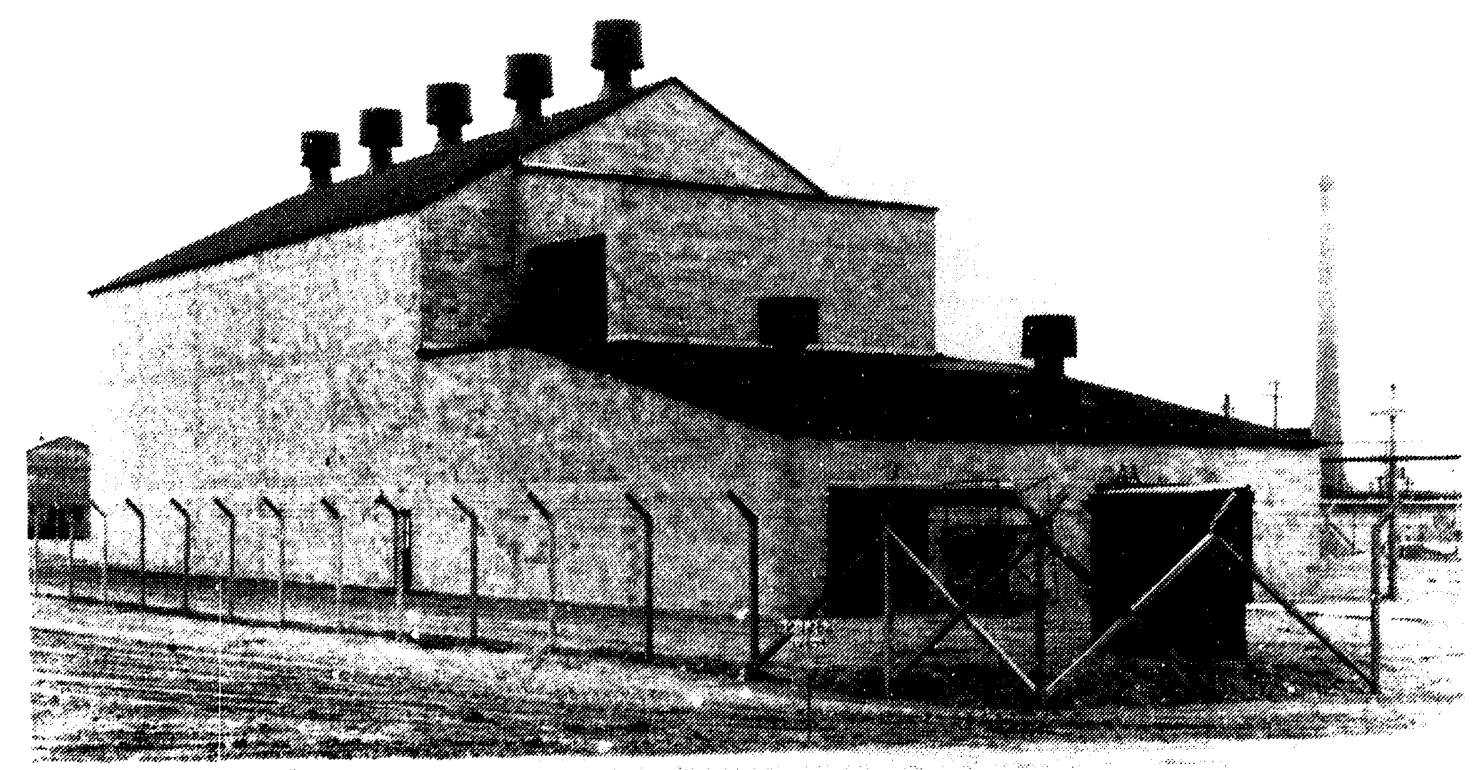

The 305 Test Pile, where the graphite for all nine of Hanford's production reactors was tested for quality, as it stood in 1945.

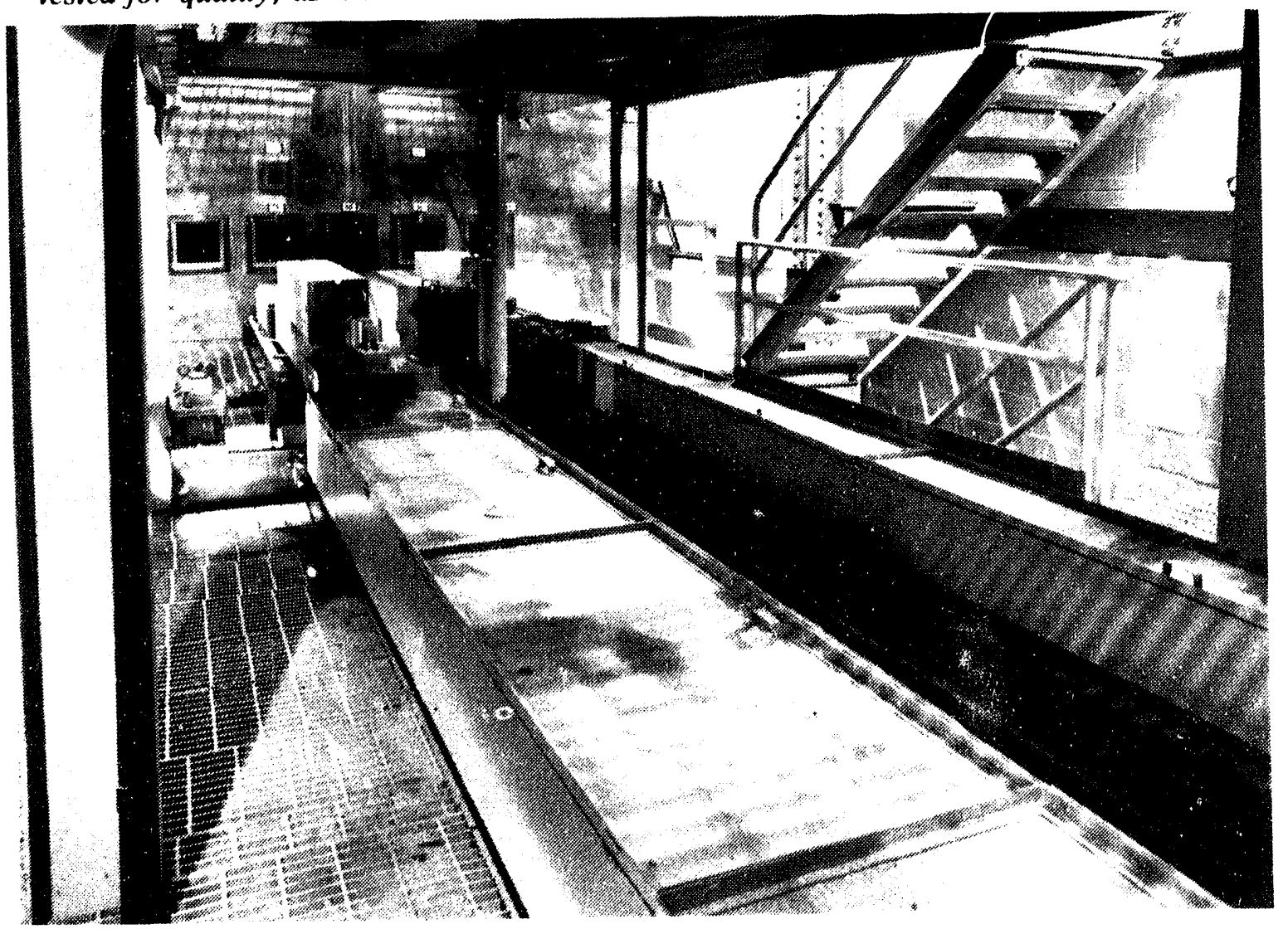

Stringer channels and entry ports into the 305 Test Pile, shown during the reactordismantling operation in 1977. 
Graphite used in the production reactors had to be very pure or it would capture too many neutrons and poison the reactivity. During the most hectic months of reactor construction at wartime HEW, so much graphite testing was needed that the 305 Test Pile was placed on a two-shift schedule almost as soon as it began to operate in March 1944. Two months later, the facility began to operate around the clock, on a three-shift basis. Graphite testing slowed considerably after August 1944. From that time until the war's end, the 305 Test Pile operated only three to four days a week on a day-shift basis only. During 1946, when production was cut back at HEW, it operated only one to two days each week. However, postwar expansions from 1947 through 1955, including the construction of five more reactors at Hanford, kept the 305 Test Pile operating full time.

\section{Testing of Bars, Eggs, and Slugs}

Graphite testing consisted of comparing one to four graphite bars of unknown purity with two standard bars in the central sections of two stringers. The purity of the test bars was reported as the difference in reactivity between the test and the standard bars, corrected to the density of the standard bars. The secondary standards of the test bars were then measured by poisoning the graphite with known amounts of neutron absorbers (in this case, copper wires).

Samples of uranium billets were termed "billet eggs" or simply "eggs." They were taken from the end of every fifth or sixth uranium ingot that arrived at $\mathrm{HEW}$ and submitted for pile testing to determine the level of impurities (especially rare earths) in the uranium. Egg testing consisted of comparing eight eggs of unknown quality, spaced along the centers of stringers, with 16 tes. eggs. The difference in reactivity between test and standard eggs was reported as the Total Danger Sum or the change in reactivity multiplication that would result if a production reactor were loaded with the test uranium rather than with the uranium containing no impurities.

Machined fuel element ("slug") testing consisted of comparing 11 test slugs with 11 standard slugs in the central portion of the metal test stringers. Slugs were tested both before and after canning, first to determine the quality of metil going into the canning process and afterwards to detect any accidental inclusion of high cross-section elements (i.e., elements having a high ability to absorb neutrons). The latter test, an impurity calibration, was performed by artificially poisoning each of the test slugs with copper foils. First one, then two, then three, and then four copper foils were added to each slug to act as neutron absorbers on the surface of the slug. Changes in reactivity values were then measured and compared.

Various other metal foils, including aluminum, gold, and indium, also were placed in the Test Pile to vary reactions and to obtain different measurements. Indium foils were used to measure neutron intensity. Under irradiation, this short half-lived element would reach a point where its rates of neutron absorption and beta decay were nearly equal. Therefore, measurements of its decay rate could give a good indication of neutron intensity at any point in the pile. Samples of iron, aluminum welding rods, lubricant oil, and boron used in the construction of the large HEW production reactors also were tested in the 305 Test Pile. Instrumentation for the 100 Areas reactors, including counter tubes, gas chambers, thermopiles, shim-stock chambers, and neutron and gamma chambers, also were calibrated in the busy little machine. 


\section{Other 305 Building Functions}

Although the 305 Reactor was primarily a "workhorse" testing device, a few critical experiments also were performed there in the early postwar years. In one case, a device was placed in the side of the reactor to extract fission gas samples. In this angular correlation experiment, the gases then were run through both beta and gamma ray spectrometers to see if decay products were emitted in certain angles from the radioactive source. Soon, however, Hanford scientists recognized the need for a separate experimental reactor and the 305-B Building was built for this purpose during 1952 and 1954.

The 395 Test Pile continued to operate as such through 1972. It performed QA trials on much of the graphite used to build $\mathbf{N}$ Reactor in the early 1960s and tested the lithium-6 (depleted lithium) values in special lithium aluminate fuel targets used to make tritium in
N Reactor in the late 1960s. From 1968 to 1973 copper silicon preshapes used in the $\mathrm{N}$ Reactor coextrusion process billet assemblies were cast and machined in the west end of the 305 Building. Thereafter, this function was moved to the 313 Building. During 1974 and 1975, the 27 tons of uranium fuel were removed from the 305 Test Pile; the reactor itself was dismantled and buried during 1976 and 1977. At that time, 474,000 tons of graphite were removed and sold as excess.

In the late 1970 s, a large addition was placed on the south/southeast side of the 305 Building, and the majority of the facility was converted to the Hot Cell Verification Facility (HCVF), a cold prototype for the 427 Fuels and Materials Examination Facility (FMEF). In 1985, the 305 Building was converted again to support mechanical development, mock-up, and testing for the Plutonium/Uranium Extraction (PUREX) Process Facility Modifications Program. Currently, the structure operates to test radioactive material shipment cylinders, casks, and capsules.

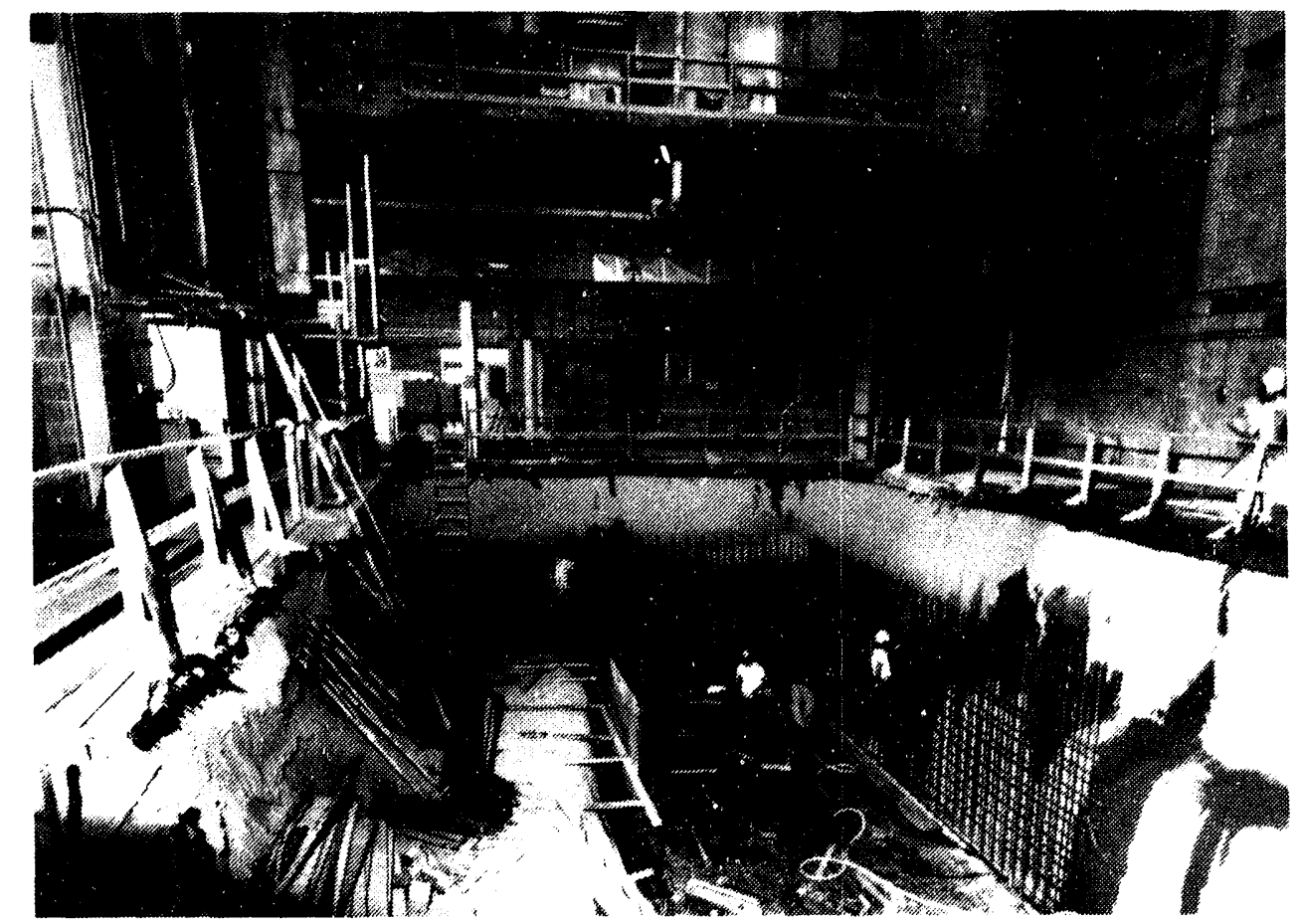

The 305 Building being modified to house the Hot Cell Verification Facility in 1978. 


\section{Early "Process Improvement" Chemical Research at the Hanford Site (321 and 3706 Buildings)}

\section{Earliest Process Development Needs}

The HEW was constructed so quickly that the processes to separate plutonium from irradiated fuel rods that came from the reactors were being developed at the same time. The duPont builders of the HEW plants have confirmed, "At the time design was begun, the [separations] process was largely undeveloped." (Ref. 5, pp. 166-167) For this reason they recognized the need for onsite research and development facilities to "study and evaluate the various steps in the process, and for process 'trouble-shooting'." (Ref. 5, pp. 166-167) The 321 and 3706 Buildings were constructed to meet this need.

\section{Building a "Cold Semi-Works"}

The 321 Separation Building was constructed during World War II as the HEW's "cold semi-works," or pilot-scale plant for testing chemical process improvements using unirradiated or low-activity substances. A series of cells and tanks ran the entire length of the building in the south half on a level 12 feet belowground. Known as the "canyon," this area housed equipment to replicate, study, and develop solutions to problems that developed in the early bismuth phosphate chemical separations process used in Hanford's T Plant and B Plant. The bismuth phosphate process itself was a means of separating plutonium from uranium and attendant fission products by repeated dissolution, precipitation, and centrifugation.
A batch operation, the bismuth phosphate process essentially achieved separation by varying the valent states of plutonium from +4 (the reduced or tetravalent state) to +6 (the oxidized or hexavalent state). In the reduced state, plutonium was carried along with various chemical solutions, and in the +6 state it dropped o: it $_{\text {of }}$ solution as a precipitate. In that form, it could be reduced again by combining it with other chemicals in a step-by-step process that eventually would yield a small quantity of purified product.

Although the 321 Building initially was conceived as a facility that would use only unirradiated substances, Manhattan Project scientists realized as early as the summer of 1944 that many variables, including acid strengths, batch size, the use of different reducing and oxidizing agents, and other factors, could affect processing operations. Additionally, they recognized that equipment corrosion studies and methods of decontamination were necessary because the operation was so corrosive, and the need for remote equipment repair was so limiting.

For all of these reasons, HEW builders decided in the early autumn of 1944 , during the equipment installation phase for the 321 Building, to add a Field Project Request for a "suitable laboratory for working with small amounts of active solutions [containing] several tenths of a curie to a curie of radioactivity" (Ref. 2, pp. 1023-1025) in that structure. Consequently, a laboratory was modified to assume the wartime mission of demonstrating "the effects of proposed process changes on decontamination" (Ref. 2, pp. 1023-1025), performing separations on small samples irradiated in the large HEW production rectors, and isolating new isotopes 


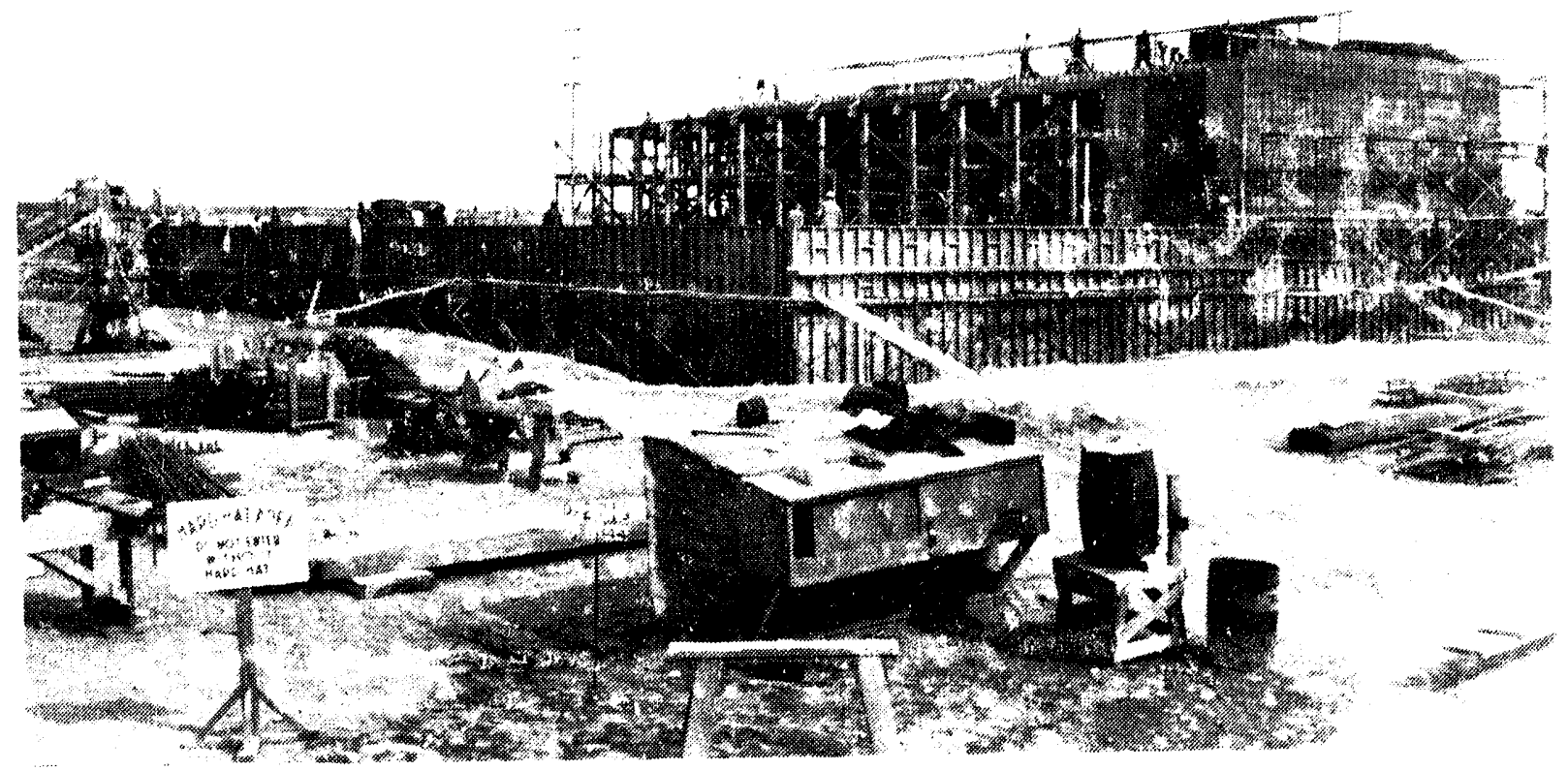

The 321 Separations Building under construction in 1944.

formed in secondary reactions in the reactors. This 321 Building laboratory also prepared "tracer" solutions (small amounts of radioactive liquids to be added to nonradioactive materials to observe and trace processes).

\section{Early Postwar Missions Important in New Chemical Developments}

In early 1947, soon after its creation, the AEC decided upon a huge expansion of Hanford. Among the Commission's highest priorities was the development of the reduction-oxidation (REDOX) process. Reduction-oxidation, a continuous solvent extraction method of separating plutonium from uranium and the attendant fission products resulting from irradiation, was seen as more efficient and much less wasteful of scarce uranium, as well as more economical. The REDOX process was developed experimentally in the 3706 Technical Building, and the pilot-scale tests were run in the 321 Building.

Most early REDOX developmental tests in the 321 Building used double-depleted uranium $(0.17$ uranium-235) that had been cycled twice through the Oak Ridge Gaseous Diffusion Plant (K-25). However, HW chemists soon discovered that some of the chemical reactions in the REDOX process worked differently on full-strength (i.e., not tracer or fractional) radiochemical solutions. Therefore, some testing with higher activity radiochemical solutions was initiated in the 321 Building and continued until C Plist a "hot semi-works" facility, was constructid in the 200 East Area in 1949.

Subsequent HW defense production expansions from 1950 to 1955 generated the development of the Uranium Plant Metal Recovery process, the PUREX process, and the reclamation of uranium and plutonium by extraction (RECUPLEX) process. Pilot-scale 


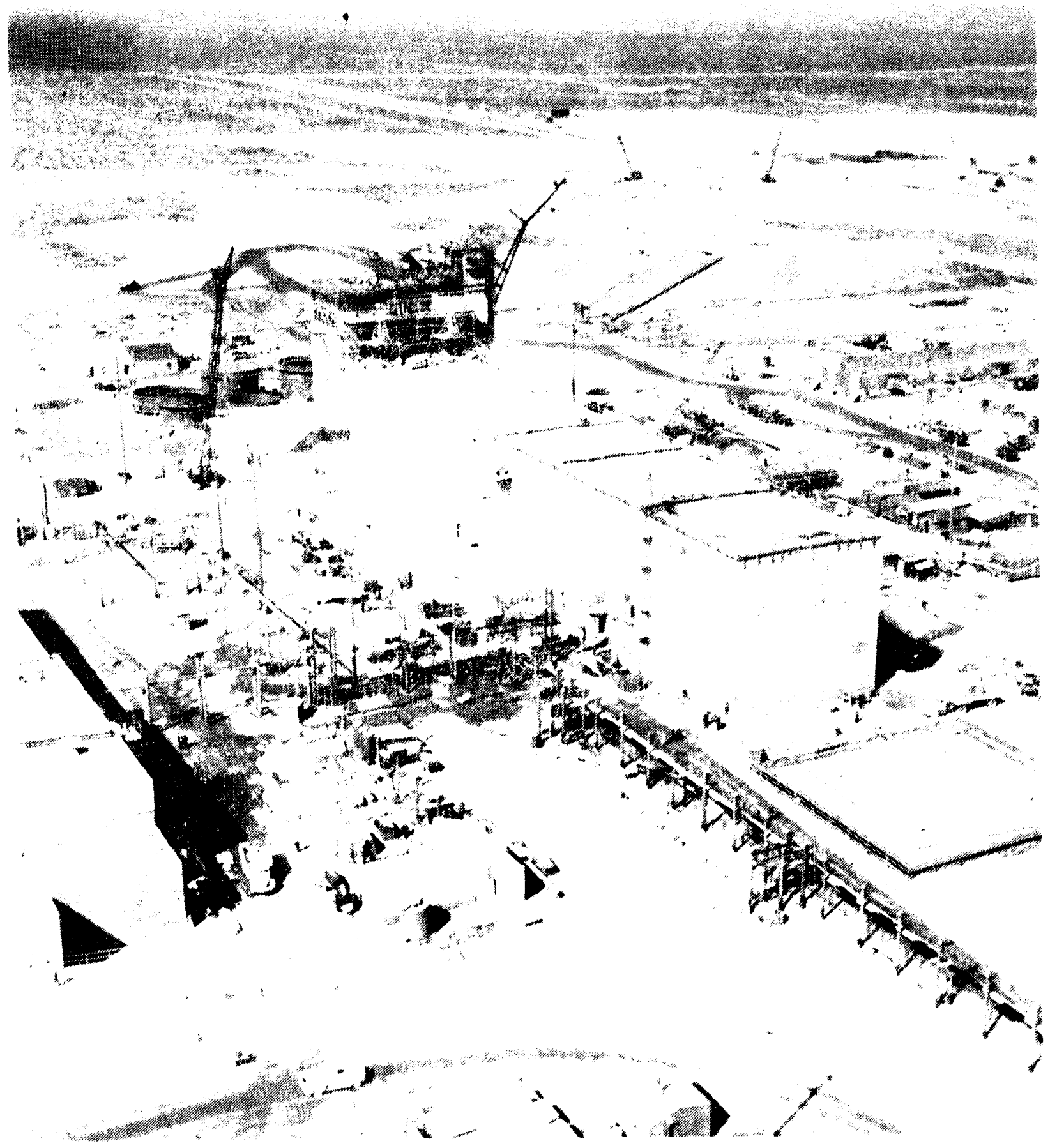

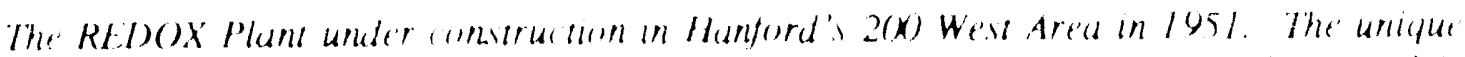

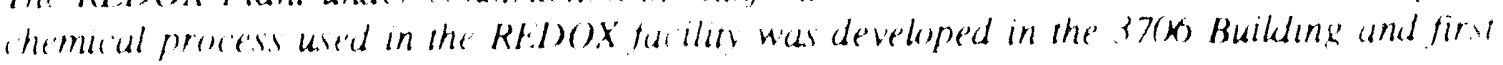
teved in the 32! Building. 
developmental testing using low-activity solutions for all of these processes was conducted in the 321 Building.

\section{Subsequent 321 Building Missions Were Varied}

Beginning in the late 1950 s, Hanford became a leading research center for the development of methods for extracting high-heat isotopes from high-level nuclear waste. Among the most prominent isotopes extracted were strontium-90, cesium-137, cerium-144, promethium-147, and neptunium-237. Many of the pilot-scale developmental tests for these extractions were conducted in the 321 Building using tracer-level waste solutions. Additionally, several different attempts were made at Hanford during the 1950 s and 1960 s to produce uranium-233 from thorium. Many of the developmental tests for these "thorex" programs took place in the 321 Building.
Beginning in 1968, pilot testing of waste vitrification processes was slated for the 321 Building. At that time, extensive building modifications and new equipment installations were undertaken, but the building proved inadequa. to the needs of vitrification work, and this program was moved to hot cells within the 324 Building. During 1977 to 1979, a cold hydraulic core mock-up for the development of the Fast Flux Test Facility (FFTF) was installed in the 321 Building. The structure was again modified during 1982 to 1984 as a Hydromechanical Test Facility, but this project was short lived. The 321 Building was deactivated in 1988 and currently is empty and sealed.

\section{Building Housed State-of-the-Art World War II Laboratories}

The 3706 Technical Building, located about 100 feet north of the 321 Building, was the original World War II radiochemistry

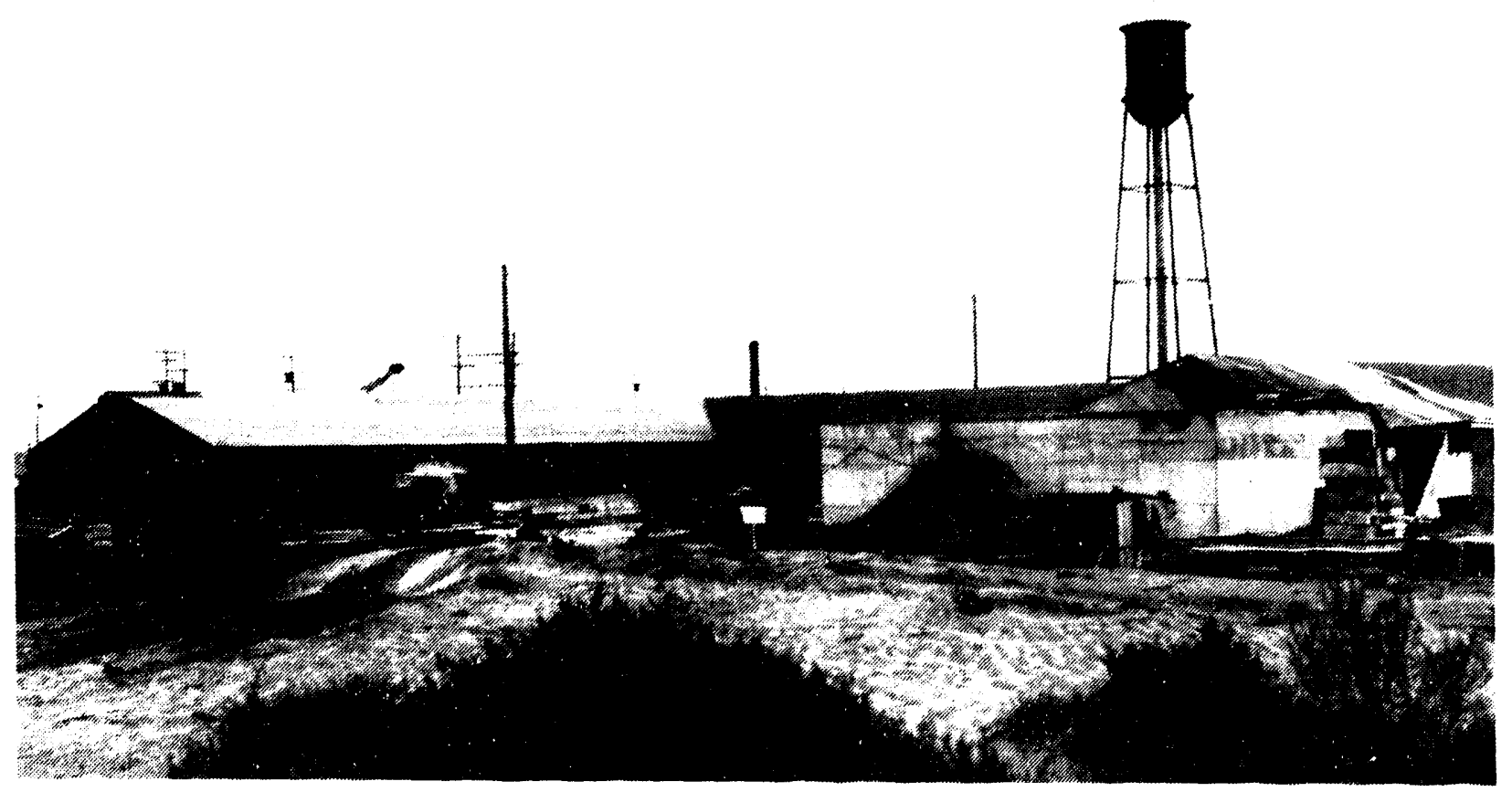

The 3706 Technical Building, earliest cinemical research and development laboratory at the Hanford Engineer Works, under construction in 1943. 
laboratory for HEW. A huge rectangular facility with a center court at one end and an open court at the other end, the structure housed 57 separate and varied laboratories. Exterior walls in the southeast portion of the building were constructed of concrete blocks. Inside that section near the center of the structure was a special laboratory reserved for the very hottest, largest volume work done in the building. It had two-foot-thick concrete walls and roof and two separate offset concrete entrances.

The original 3706 Building mission was to perform small-scale experiments with both low- and high-activity radioactive materials in support of all HEW production activities. The largest portion of staff and facilities in the building performed radiochemical trials aimed at improvements in the bismuth phosphate process. During the war years, many variations in the strengths of acids in the separations process were studied, making possible much reduction in the use of fresh chemicals. Additionally, a shortening in the "digestion time" in the reduction step, first researched in the 3706 Building, allowed significant reductions in the process time cycle for T Plant and B Plant.

Other large sections of staff time and laboratories in the 3706 Building were devoted to metallurgical examination of irradiated fuel elements from the reactors, fuel development for the 313 Building, examination of graphite from the experimental levels of the production reactors, special sample analyses from the 200 Areas separations plants, spectroscopy and radiocounting activities, and multifaceted sample analyses for the Hanford environmental and personnel survey programs.

\section{Postwar Help to REDOX, PUREX, RECUPLEX, and Other Hanford Processes}

In 1947, under direct and urgent orders from the AEC, the primary 3706 Building mission changed from bismuth phosphate process improvement studies to the development of the REDOX process. From 1947 to 1953 much pioneering radiochemical work in the development of the REDOX, PUREX, and RECUPLEX processes took place in the 3706 Building. After initial laboratory-scale development in this facility, the new processes were tested on a pilot scale in the 321 Building and/or C Plant. Metallurgical, physics, and counting functions also continued in the 3706 Building. In the early 1960s, some of the first computers at HW were installed in a small annex known as the 3707-D Computer Laboratory.

In 1952 to 1953 , several new laboratories with "hot cells" and equipment more modern than that of the 3706 Building were built in the 300 Area. At that time physics and metallurgical work, as well counting and spectroscopy studies and high-activity chemical work, were transferred to these newer facilities. In 1954, the 3706 Building underwent a major decontamination and remodeling effort in which many of the laboratories were converted to offices. However, control (sampling) laboratories for uranium fuel fabrication operations continued to operate in the building through the mid1960s.

By 1964, the 3706 Building was called the General Services Building. Although it still 


\section{WHC-MR-0440}

contained some analytical laboratories, a majority of its space was devoted to mail services, duplicating, photographic and drafting services, a first aid station, 300 Area patrol headquarters, and other administrative and clerical functions. During the 1970 s and 1980s, the 3706 Building underwen several other minor remodelings as all laboratory work eventually was nhased out. Today, the structure houses the Westinghouse Hanford Company Central Files as well as duplicating, publications, and other support services. 


\section{Major 1952 and 1953 Expansions in the 300 Area (325 and 329 Buildings)}

The years 1947 to 1955 brought continual expansions to the HW. Undertaken in response to perceived Cold War imperatives, three huge expansion periods brought the federal government's capital expenditures at $\mathrm{HW}$ up from approximately $\$ 250$ million at the close of World War II to just over $\$ 1$ billion in 1955 . At that time, HW operations were split into three major segments: the Irradiation Processing Department for reactor operations and fuel fabrication, the Chemical Processing Department for chemical separations work, and Hanford Laboratories Operation (HLO) for research and development. In the 300 Area many new buildings and facilities were constructed, most of which were part of HLO. Of these, the most prominent were five large laboratories and shops known as the 325 Radiochemistry Building, 326 Pile Technology Building, 327 Radiometallurgy Building, 328 Engineering Services and Safety Shop, and the 329 Biophysics Laboratory, all of which opened in 1952 or 1953.

\section{State-of-the-Art 325 Radiochemistry Building}

Among these new structures, perhaps none typified the expansive and optimistic attitudes toward nuclear energy more than the 325 Radiochemistry Building. Completed in 1953, this facility was built to safely house and handle multicurie-level chemical development work with high-activity substances. From 1959 to 1960 , a large addition known as the High-Level Radiochemistry wing was constructed, making the overall building the largest among Hanford's laboratories (approximately
140,000 square feet). In its years of prime use in the 1960s, the building housed over 50 laboratories and 11 hot cells. It also contained over 20 laboratory hoods and many gloveboxes for work with radioactive materials.

The entire ventilation system was engineered in a reverse flow, which was a state-of-the-art concept in the 1950s. All air pressure was below atmospheric but was highest in offices so that air passed first through these facilities, then through corridors, then through cold and low-level laboratories, and then through hot cells (where air pressure was lowest). The original filtration system consisted of Chemical Warfare Service (CWS) and charcoal filters. High-efficiency particulate air (HEPA) filters were installed in the early $1960 \mathrm{~s}$, and a second HEPA filtration bank was emplaced for added protection in 1970. Air in the cell and laboratory sections of the building was completely changed and recirculated about every two minutes, but air changes in the offices and corridors occurred less frequently.

The original 325 Building contained eight hot cells, each 6 feet by 6 feet by 5.5 feet (deep) surrounded by 2.5 -foot-thick concrete walls with stainless steel liners. Three larger hot cells were added in the 1959 to 1960 construction of the High-Level Radiochemistry wing. The largest, A-Cell, was 15 feet by 16 feet by 6 feet (deep); the others, B- and C-Cells, were 15 feet by 7 feet by 6 feet (deep). All of these larger cells were surrounded by 4-foot-thick high-density concrete walls with stainless steel liners. Each of the 11 hot cells was equipped with remote manipulators (hydraulic in the earlier cells and electric in the cells built later), periscopes, and lead glass windows. 


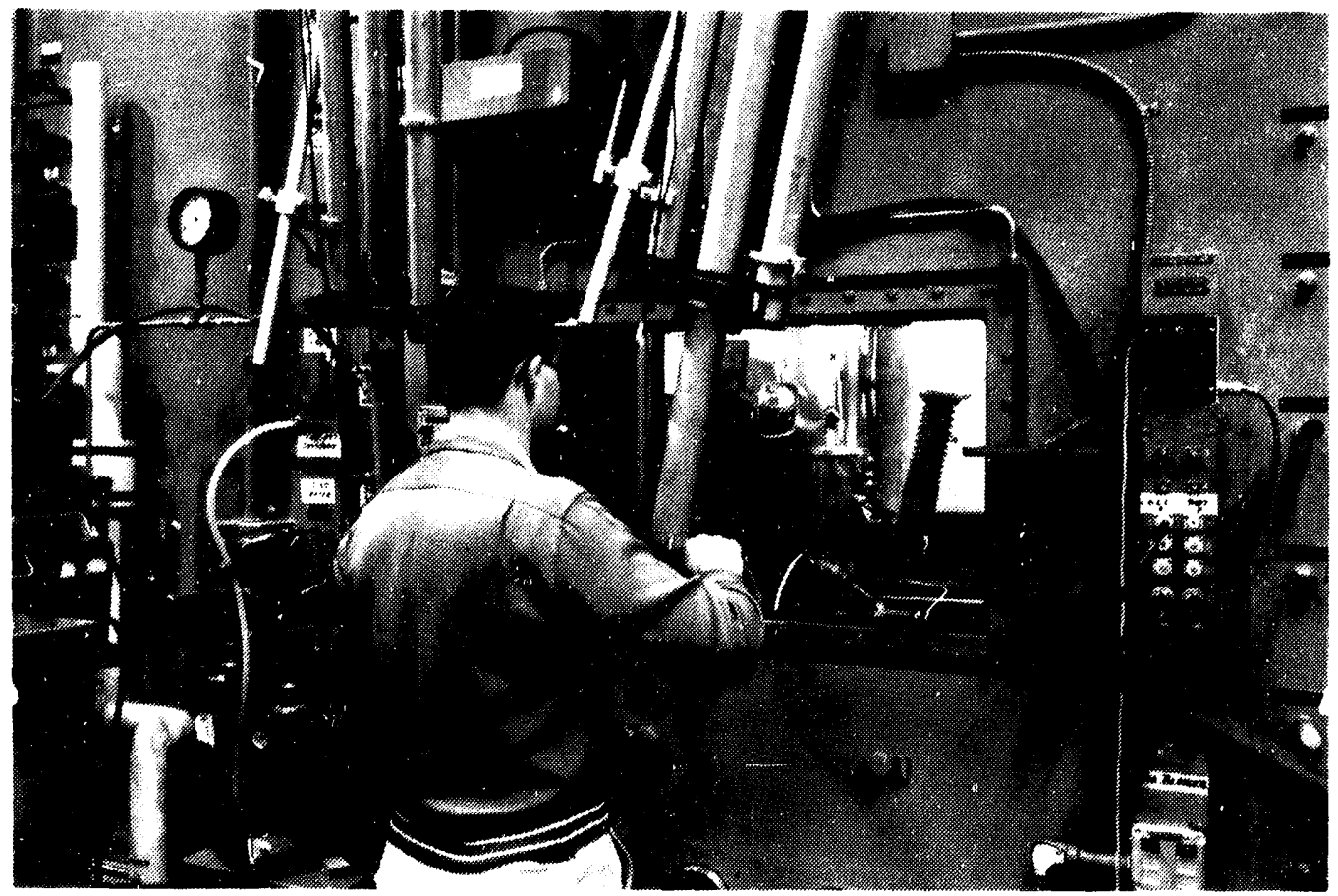

Above, a worker operates the state-of-the-art hydraulic manipulators at the face of a hot cell in the 325 Radiochemistry Building in the 1950s. Below, a HAPO-1-A Cask arrives at the entrance to the rear face of the three large new hot cells in the building in 1961. The cask contained radioactive material being used in pioneering "isotope campaigns" at the Hanford Works.

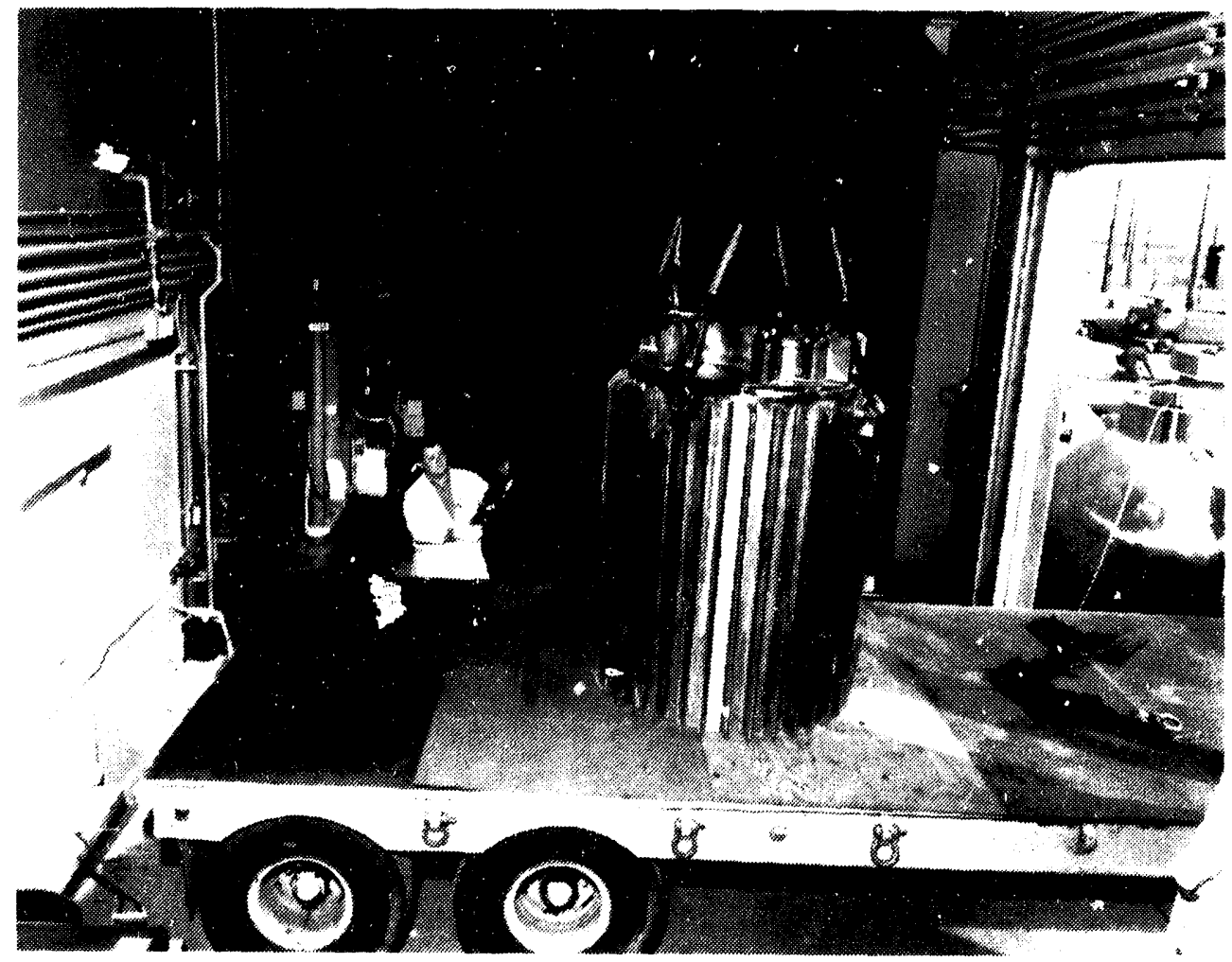




\section{Original 325 Building Missions}

The original project proposal for the 325 Building stated that it was "urgently needed to support existing processes and to explore improvements in them." (Ref. 6, pp. $8,13,26)$ Initial building missions listed as high priorities included production support and process improvement for REDOX, improvements for the Uranium Metal Recovery process, and studies of separations waste treatment aimed at development techniques to reduce high-level wastes to lower activity levels. Other important early missions were stated as production development for (radioactive lanthanum), which is a tracer gas in nonnuclear test explosions, temporary technical support to the bismuth phosphate process (until this process could be completely replaced by solvent extraction separations at $\mathrm{HW}$ ), support studies for tritium production, and basic investigations of plutonium chemistry (described by Site officials as being of "outstanding interest to the Hanford Works"). (Ref. 6, pp. 8, 13, 26) These missions, along with development of the PUREX, RECUPLEX, and Plutonium Recovery Facility processes, occupied the 325 Building during its first decade of operations.

\section{Isotope Campaigns}

The High-Level Radiochemistry addition, with its three larger hot cells, was completed just in time to house several pioneering "isotope campaigns" at HW. During the 1960s the burgeoning United States space programs and experimental new programs using radioisotopes for medical purposes brought National Aeronautics and Space Administration and many medical research facilities to $\mathrm{HW}$ as prime customers. In many cases, HW high-level waste was the prime or only source to supply these isotopes. A number of new techniques developed in the 325 Buil-ting separated or fractionized specific isotopes from high-level waste by ion exchange, carrier precipitation, solvent extraction, and various combinations of these and other methods. The feed material was generally PUREX 1WW (first cycle waste) or waste from the commercial nuclear power plant at Shippingport, Pennsylvania.

The isotopes in highest demand included strontium-90, cesium-137, curium-244, americium-241, and promethium-147. During the first years of operation, 14 million curies of promethium-147, 1 kilogram of strontium-90, 3 kilograms of americium-241, and 65 grams of curium-244 were purified in A-Cell. Strontium fluoride and cesium chloride encapsulation chemistry also was studied, as were compatibility tests for strontium fluoride capsule development. Experiments in the recovery of plutonium-238 from special, irradiated neptunium-237/ aluminum target material also took place.

\section{Waste Vitrification and Other Projects}

The development of workable methods of vitrifying (solidifying or "glassifying") high-level waste into solid ceramic form also became a high priority at $\mathrm{HW}$ during the 1960s as concerns over tank space and underground waste migration mounted. From 1962 to 1964 , waste solidification tests and demonstration of an early phosphate glass melter were conducted in A-Cell. At that time, the first spray calcination of 200 gallons of PUREX 1WW was achieved. Vitrification studies continued through 1980 . Since then, remaining available cell space has been used 
for materials characterization leach tests of waste glass and of spent nuclear fuel, postirradiation examination of the boron thermal shield from $\mathbf{N}$ Reactor, and characterization of neutralized cladding removal waste (along with the testing of a potential method of converting it to nontransuranic waste).

Meanwhile, other radiochemical work conducted in the 325 Building hot cells has included characterization of double-shell tank slurry, tests of fuel iodine control and fuel uranium dissolution methods for $\mathbf{N}$ Reactor, and experiments in the recovery of strontium using antimonic acid. Other experiments examined high-level waste behavior during thermal concentration and light-water reactor fuel dissolution tests for waste partitioning. During the same period, demnnstrations of the molten salt electrodeposition of uranium oxide and plutonium oxide occurred, as did solvent degradation tests that were part of FFTF development. The facility now is called the Applied Chemistry Laboratory.

\section{Biophysics Laboratory}

The 329 Biophysics Laboratory, also completed in 1953, was another structure that typified the optimistic approach to nuclear energy that was characteristic of its era. It was constructed to support the pioneering HW environmental monitoring and bioassay programs that were developed at the Hanford Site during the 1940s and 1950s. As part of this new program, a Health Instruments Control and Development Laboratory was proposed in 1949. Soon afterward it was constructed and renamed the Biophysics Laboratory.

The original building consisted of three sections (A, B, and C). Sections A and B contained a mixture of laboratories, offices, chemical storage rooms, and counting rooms, with two particularly large counting rooms. Atmospheric pressure barriers operated in Sections A and B to bring air to offices and corridors first and to laboratories just before exiting the building. In 1970, HEPA filters were installed in some laboratory hoods in these sections.

Section $\mathbf{C}$ was a large machine/fabrication shop equipped with lead bricks to fabricate, test, and calibrate radiation measurement instrumentation. In 1974, Section D, a pit known as the Neutron Multiplier Facility, was added to the building, but it did not receive nuclear material until a californium-252 neutron source for sample irradiation was emplaced in 1977. There were no hot cells in the 329 Building, although thousands of lead bricks were used to construct walls, partial enclosures, and "caves" to shield work with radioactive substances.

The primary, original mission of the 329 Building was to house the preparation and counting of radioactivity levels in samples taken of the air, vegetation, soil, wildlife, river and well water, and various types of bioassay samples. Other building functions included the development of new sample counting procedures and methods, the invention and improvement of radiation monitoring and analytical instruments, and the application of industrial hygiene techniques from other industries to Hanford's health physics needs.

Very soon after the structure was completed, building programs expanded to include a major role in monitoring and counting fallout from atmospheric nuclear bomb tests conducted by the United States and the USSR and later by Great Britain, France, and China. Scientists in the 329 Building also conducted fission product 


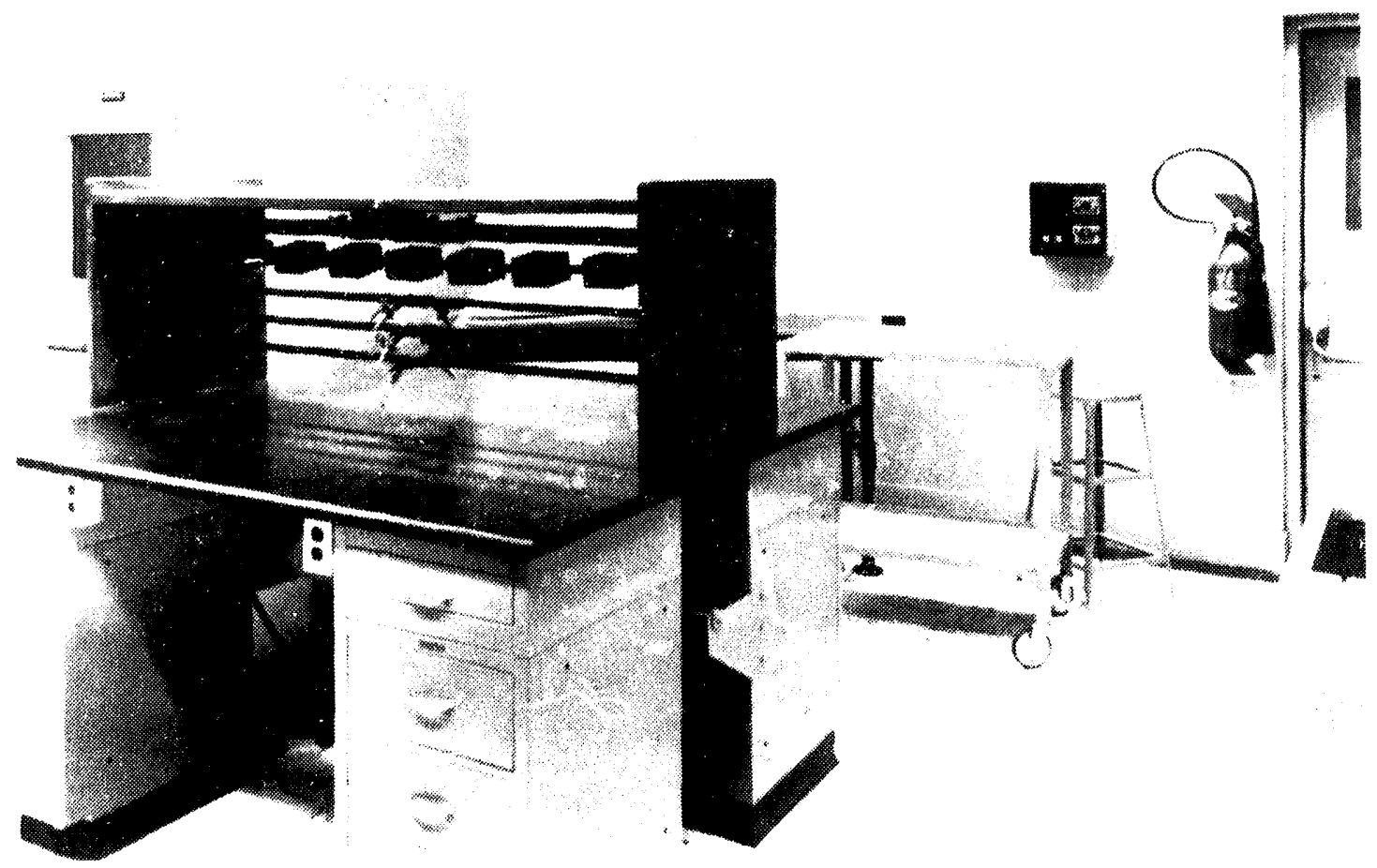

The Shielding Instruments Development Laboratory nearly :omplete in the new 329 Biophysics Building in late 1952.

analysis on ocean and marine life samples taken for hundreds of miles around the Pacific Proving Grounds over a period of nearly two decades, and they performed fallout deposition studies on caribou and other terrestrial organisms in Alaska. Marine life and other tissue analyses also were performed in 329 Building programs when radionuclides from HW were found in shellfish in Pacific coastal waters near the mouth of the Columbia River in the late 1950s.

In the 1970s and 1980s examinations of moon rock, oil shale, solvent refined coal, and volcanic ash from Mt. St. Helens also were conducted in the building. Today the building is called the Chemical Science Laboratory. 


\section{WHC-MR-0440}

This page intentionally left blank. 


\section{Early 300 Area Facilities Constructed to Support Reactor Development (326 and 327 Buildings)}

Throughout the 1950s and into the 1960s, HW was on the cutting edge of reactor development. Experimentation with higher power levels, new lattice configurations, and cooling methods and trials with varied materials and designs in process tubes and fuel elements were proceeding quickly and simultaneously. Site planners recognized the need for laboratory facilities dedicated to direct support of reactor development.

\section{Pile Technology Building}

The 326 Building, known early on as the Pile Technology Building, opened in 1953 with two primary missions associated with the support of production pile (reactor) operations. According to HW planners, the facility was constructed to "assure continuity of operations [of production reactors], to maintain and to improve the present plants [reactors], and to develop the technical information required for the design of future plants." (Ref. 6, p. 57)

The primary physics mission was to conduct the exponential pile physics development work that had been done first in the P-11 Project and later in the 189-D Building. This work consisted of approach-to-critical lattice design experiments conducted in graphite piles directed toward finding new lattice configurations to improve reactor efficiency and safety. During the earliest years of building history 4-foot, 8-foot, and 12-foot graphite cubes operated as approach-to-critical exponential piles in large basement laboratories.
The primary metallurgical mission was to examine reactor components and fuel elements to evaluate characteristics and performance. This work was performed on unirradiated fuels (either natural uranium or $90 \%$ enriched uranium) and on irradiated metal specimens. Some early analysis of irradiated graphite also took place in the 326 Building, but the samples were ground up and prepared elsewhere. Solid-state nondestructive examination (NDE) methods, such as X-ray diffraction, ion microprobe, and other spectrometry work, were the principal means of analysis used. Fuel jacketing process improvement studies also were conducted, including etching experiments and experiments with aluminum-silicon blends, beryllium-zirconium ratios, and various other alloys. Plutonium and plutonium oxide fuels experiments also were conducted in the 1960s as part of the Plutonium Fuels Utilization Project.

The original 326 Building, 190 feet by 180 feet by 38 feet (high), contained a special counting room with high-density concrete walls. The remainder of the building housed offices and multiple laboratories. The building contains no hot cells, but work with high-activity substances was performed in lead brick "caves" that sometimes were termed "hot cells" in slang usage. The CWS filters originally operated in individual laboratory hoods, but these were replaced by HEPA filters about 1960.

In the 1970s and 1980s several of the laboratories were converted to accommodate chemical work involving unirradiated or low-level radioactive materials. The central 


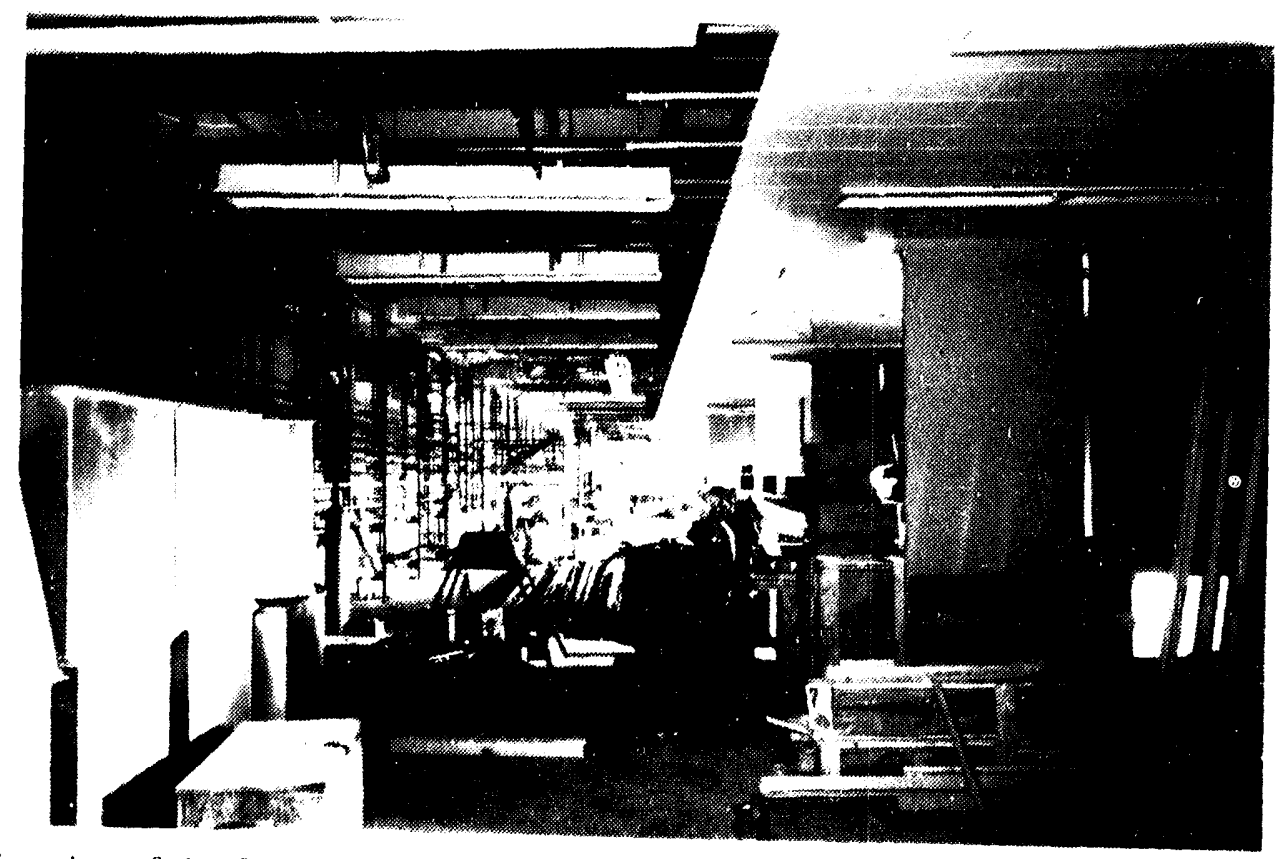

Interior of the 326 Pile Technology Building under construction in late 1952.

mission continued to be the support and study of reactor cotiponents and fuel elements during this period, including development and analysis work performed for the Plutonium Recycle Test Reactor (PRTR), N Reactor, the High-Temperature Lattice Test Reactor (HTLTR), and the FFTF. These studies were enhanced by the addition of equipment. including mass spectrometers, electron microprobes, quantitative image analyzers, and tensile test equipment. The building now is called the Material Sciences Laboratory.

\section{Building Wastes and Contamination}

The earliest wastes of concern in the 326 Building came from the exponential piles that operated in the basement. Shielded only by lead brick piles and caves, pile experiments used polonium-beryllium and radium-beryllium sources to irradiate cobalt, copper, and other metallic foils. Such foils then were examined in hoods and lead caves. Sometimes inadequate shielding around the piles and irradiated samples caused gamma shine in building hallways. but radiation levels in the building decreased significantly after the Critical Mass Laboratory (209-E) was constructed for pile work in 1961

Wastes generated by metallurgical work in the 326 Building consisted primarily of chemicals and heavy metals. Particulate wastes, in the form of uranium and beryllium powders (called "fines") and grindings, were collected in a "hag" filter system before the installation of HEPA filters. Some of these escaped into and through the vent system. High-energy electron microscope work with plutonium samples and irradiated steel samples produced contamination spreads in the building in 1971 and 1972. A 1980 and 1981 building upgrade found much mercury in the drain system and basement. Later in the 1980s, a diverter line built to carry waste out of the building experienced multiple problems. including valve and instrumentation malfunctions, including two cases wherein radioactive liquid backed up into 326 Building laboratories. 


\section{Radiometallurgy Building}

The 327 Building opened in 1953 to house the examining and testing of irradiated materials, particularly fuel elements and fuel cladding materials from and for the $\mathrm{HW}$ production reactors. It replaced the World War II Test Building (111-B), where the earliest Hanford metallurgical work had been done. The original 327 Building mission was conceived as "largely one of plant assistance to the present piles." (Ref. 6, pp. 45-46) It was extremely important in the early 1950s, when HW's primary task of production was increasing yearly, to determine the "nature and causes of dimensional instability" (Ref. 6, pp. 45-46) in fuel elements and the effects of irradiation stresses on pile materials.

Specific early reactor problems addressed in 327 Building studies included the "blistering" or distortion of fuel elements during irradiation, the control of uranium grain structure during fabrication and of uranium "growth" during irradiation, and the metallography of canning and corrosion. The effects of higher power levels of irradiation on new and different pile structural materials also was assigned as an important "long-range mission" (Ref. 6, p. 37) early in 327 Building history.

The original facility received two additions and two major modifications during its first 10 years, bringing the total area to just under 30,000 square feet. The main laboratory area is an east-west "canyon" 210 feet by 29 feet by 21 feet (high) that originally held eight small hot cells (B, C, D, E, F, G, H, and I), two water basins for holding irradiated fuel rods, two lead brick cells, a burst test facility, and a decontamination chamber. Each original cell had a 14-square-inch lead glass window (the largest available at the time) and hydraulic manipulators. A-Cell, comparable in size and construction to the first eight cells, was added in 1960 . In 1970 the decontamination chamber was torn out to make room for the Special Environmental Radiometallurgical Facility (SERF), a large hot cell with a controlled atmosphere of inert nitrogen. The SERF contained an operating area of 12 feet by 6 feet by 8 feet (high), with an additional storage area of 4 feet by 4 feet by 5 feet. It had electric manipulators and 18.5-inch-thick steel plate walls.

The building always has been equipped with a double air filtration system. Originally, each cell had its own bag filter, supplanted by a HEPA filtration system about 1960 .

Stainless steel ducts also contained additional filtration (originally CWS but later HEPA combined with charcoal filters for iodine-131 control) and led to a 44-foot-high stack. The entire building was maintained on air pressure lower than atmospheric, with hot cell air kept at the lowest pressure of all to ensure that air flowed from offices to canyon to cells and then through the filtration system and up the stack.

\section{0s Through 1980s Missions Varied and Exciting}

Missions conducted in the 327 Building in the late 1950s and early 1960s included the establishment of specifications for $\mathbf{N}$ Reactor fuel rods and process tubes, the conduct of destructive examination (DE) and NDE to evaluate the performance of these rods and tubes after N Reactor startup in 1963, and the examination of various isotope combinations and capsules. As part of Hanford's waste vitrification projects of the $1960 \mathrm{~s}$ and $1970 \mathrm{~s}$, performance evaluations of both components and glassified products were conducted in the 


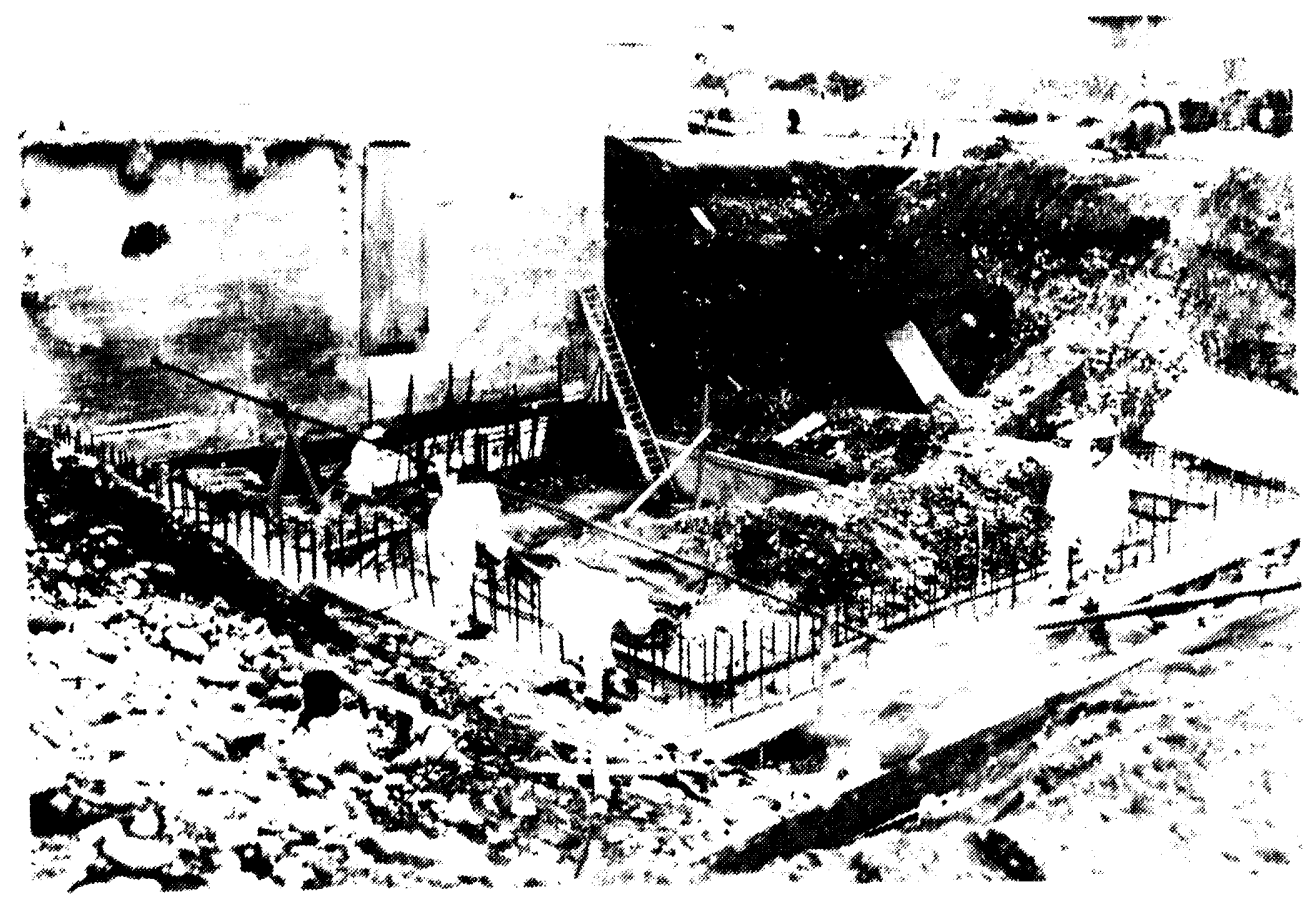

Above, the 327 Radiometallurgy Building receives its High-Level Radioactive Material Receiving and Storage addition in 1958. Below, the "canyon" area lined with hot cells in in the building about 1970.

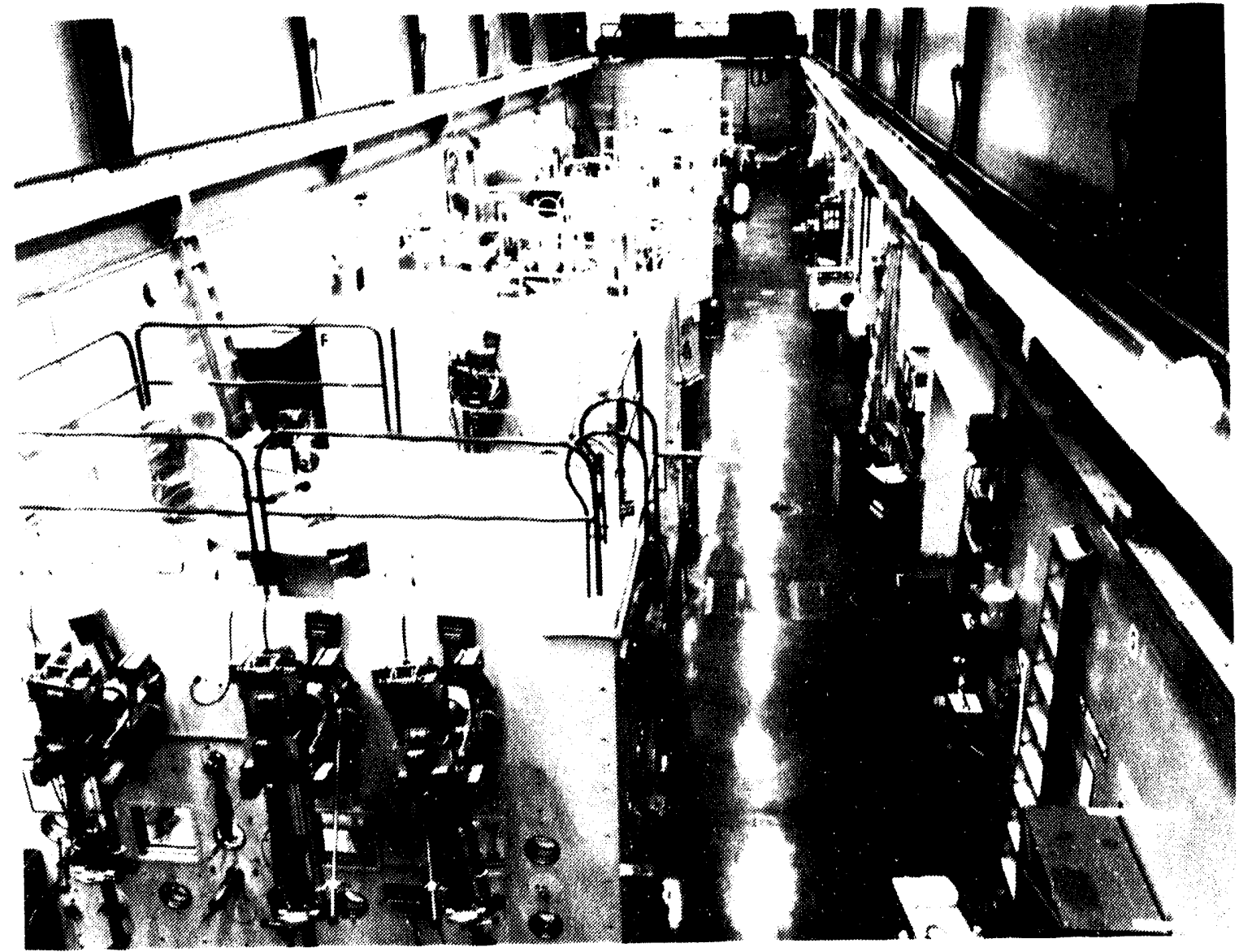


327 Building. Both DE and NDE analyses also were performed from the $1960 \mathrm{~s}$ through the 1980s on fuel rods from the PRTR and the FFTF; from a commercial, enriched uranium oxide-fueled, fast flux test reactor built in California; and from the Experimental Breeder Reactor II (EBR-II) and the Materials Test Reactor (MTR) at the Idaho National Engineering Laboratory.

In the course of this work, several pioneering fuel examination and recording techniques were developed in the

327 Building. Among these were the capacity to produce multidimensional photomosaics to depict all facets of metallurgical results and the development of nonphotographic recording capabilities and of neutron radiography film. Additionally, the new concept of "gas tagging" and the development of "cover gases" for the FFTF achieved reality through work largely conducted in the 327 Building. About 1980 the building was renamed the Postirradiation Testing Laboratory.

\section{Building Wastes and Contamination}

The very nature of the work performed in the 327 Building involved and generated extremely high-activity wastes. Irradiated materials, including ruptured or failed fuel rods containing plutonium and fresh fission products, were examined while they were "green" (i.e., when they had experienced very little decay or stabilization time). Destructive examination of an irradiated fuel rod called for drilling a pinhole from which was collected a fission gas sample. Next the element was sawed open, and a metallurgical sample was ground and polished for analysis. Irradiated process tubes and other reactor components likewise were cut, ground, and polished to produce workable samples. The irradiated fines generated by this work became airborne and occasionally escaped complete capture in the filters. Additionally, they sometimes entered liquid waste streams and clogged pipelines carrying these wastes to disposal facilities.

Sometimes contamination spreads occurred within the 327 Building as the result of the transfer of radioactive materials and of wastes in and out of hot cells and/or radioactive materials storage basins. Other transfer problems occurred at the truck loading area on the building's north side when incoming sample containers leaked. Cell, drain, and waste piping leaks also accounted for some of the contamination events in 327 Building history. Liquid waste from this facility included various irradiated materials dissolved in an array of chemical reagents and cell cleansers, including carbon tetrachloride, acetone, ethanol, kerosene, many commercial products, and others.

In some cases, explosions and/or fires spread contamination in and around the 327 Building. Among these events was a sodium-potassium explosion that occurred in F-Cell in January 1976. A more serious explosion took place in February 1986 in SERF Cell, when ethanol in the cell atmosphere ignited as an electric vacuum cleaner was turned on during cell decontamination operations. One cell plug blew out, allowing plutonium and other fission products in the cell to be spread around the canyon to varying degrees. The cleanup from that explosion required seven months. 
WHC-MR-0440

This page intentionally left blank. 


\section{Hanford Site Ventures With the "Peaceful Atom": The 309, 308, and 318 Buildings}

\section{Eisenhower's "Atoms for Peace" (Ref. 1)}

The mid-to-late 1950 s was a very expansive time in United States nuclear history. The belief was widespread that atomic energy would be the fuel of the future adopted for virtually all civilian and industrial power needs. Knowing that worldwide supplies of uranium were limited, the AEC directed the HW to embark on a large research effort to develop and test alternate fuels. The most ambitious early efforts were directed at demonstrating the effectiveness of various plutonium oxide and mixed (plutonium, uranium, and other metallic) oxide fuel blends. Several faci'ities, including the 309, 308, and 318 Buildings, were constructed for this purpose.

\section{Plutonium Recycle Test Reactor}

The PRTR, located within and below the 309 Building, was completed in 1960 as the operating test reactor in the HW Plutonium Fuels Utilization Program. The PRTR itself sat in a calandria (tank) located in the center of the containment vessel. The reactor core consisted of 85 vertical aluminum tubes. Zircaloy-2 process tubes fit inside these aluminum tubes, and each held a fuel "bundle" or "cluster" of 19 fuel rods. Primary control was achieved by varying the level of the heavy water moderator. The PRTR also had a secondary light water coolant that ran through a large pressure tube in the center of the calandria.
Below the reactor were located three large cells with their floors 32 feet belowground. These were known as the "minus 32 feet" facilities. A-Cell was the largest, occupying nearly half of the area under the 80-footdiameter containment dome. It was the reactor process cell, containing pumps and motors for both the primary and secondary coolant systems, as well as the heat exchangers. The B-Cell occupied about one-fourth of the area under the containment dome and was the experimental cell. It contained the in-vessel rupture loop equipment, the gas loop equipment, and cooling blowers for the Fuel Examination Facility. C-Cell, about the same size as B-Cell, was the instrumentation cell.

\section{Hot Fuel Examination Facility and Fuel Storage Pits}

Other portions and equipment of the 309 Building included a Hot Fuel Examination Facility located at "minus 32 feet" between A-Cell and B-Cell. It functioned as a hot cell where personnel conducted preliminary gamma ray scans and other tests on breached irradiated fuel to study warpage, swelling, and other characteristics. Between A- and C-Cells, approximately 30 teet belowgrade, was located an irradiated fuel storage pit. The 309 Building also contained a green (fresh) fuel storage pit located belowgrade between A-Cell and C-Cell and just north of the Irradiated Fuel Storage Pit. 
WHC-MR-0440

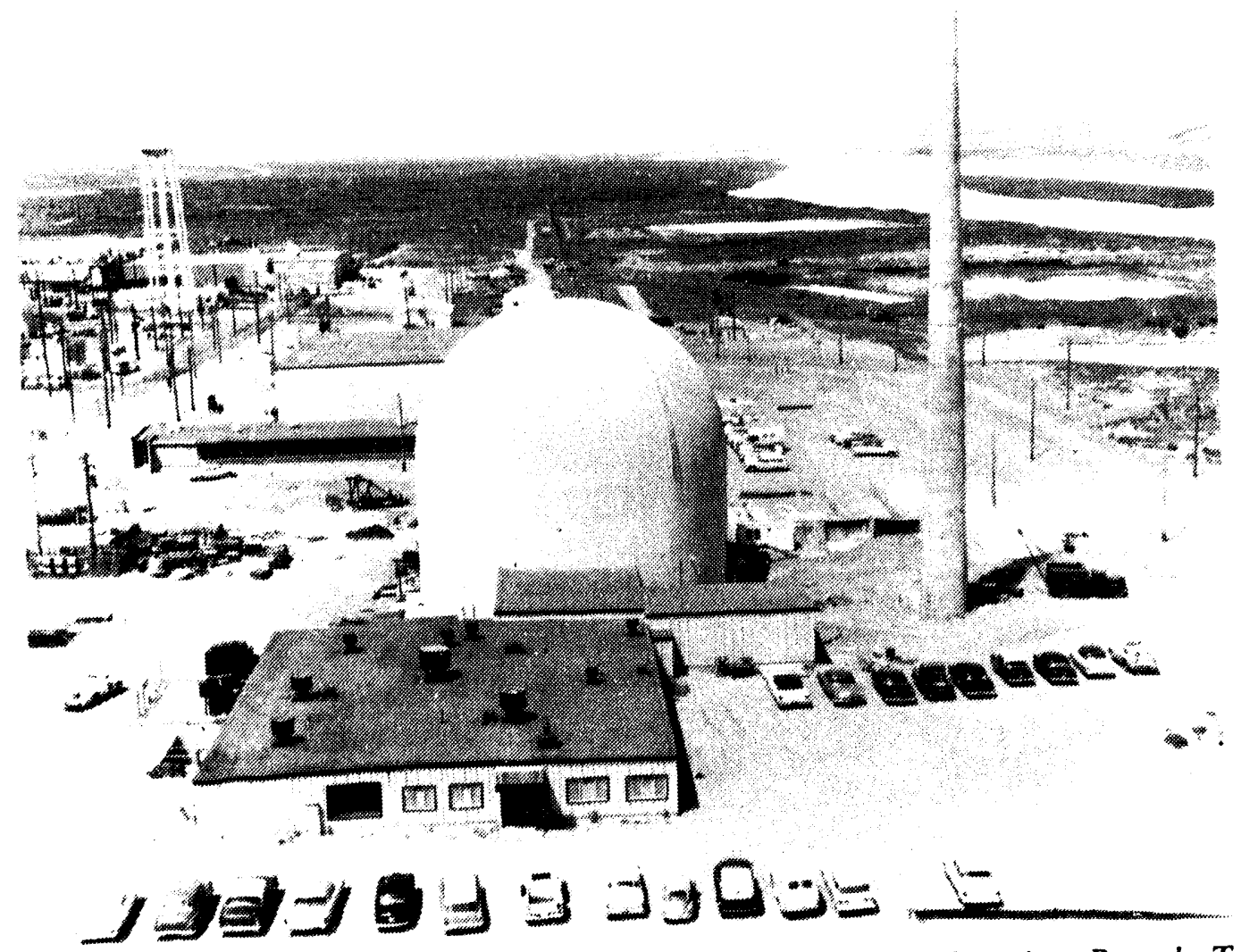

Above, the 309 Building's distinctive silver dome, housing the Plutonium Recycle Test Reactor (PRTR), as it appeared during its first year of operation in 1960. Below, Hanford workers prepare the initial fuel assembly for the PRTR in 1960.

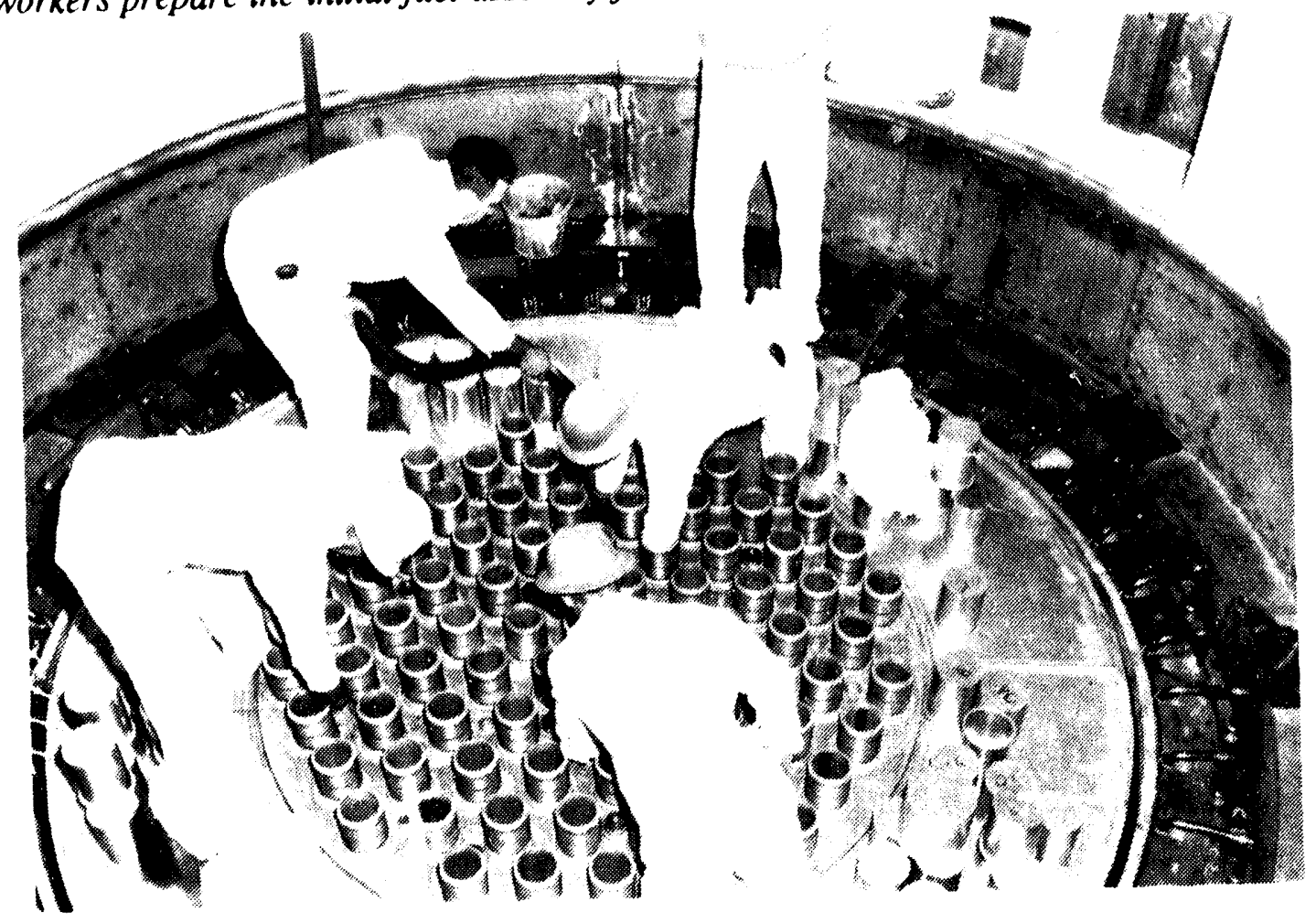


In 1960 a maintenance and mock-up wing was added west of the containment dome, with the unique feature being a belowgrade open mock-up area designed to resemble one quadrant of the PRTR containment area. The mock-up area (sometimes called a "cell" but not truly a hot cell) was used for cold prereactor assemblies.

\section{Plutonium Recycle Critical Facility}

A second addition, built east of the containment dome of the 309 Building in 1962 and 1963 to house the Plutonium Recycle Critical Facility (PRCF or the "Critical Facility"), was located belowgrade in a heavily shielded concrete cell. The Critical Facility itself consisted of an aluminum tank containing a heavy-water moderator with fuel elements suspended vertically from a top grid plate. Originally, the PRCF was designed to support PRTR operations as the place where the reactivity values of the fuel assemblies before and after irradiation were chec..d. However, its major mission soon became housing experimental lattice testing for the design of various light-water-cooled reactors. A commercial license was obtained from the U.S. Nuclear Regulatory Commission along with special permits from the AEC. These permits allowed the PRCF to operate as a private business venture, housing experiments for both government projects and for private nuclear fuel vendors until 19?6. It closed when computational tools became advanced enough to replace most of its testing capabilities. From 1988 to 1989, PRCF hardware and equipment were removed and buried in the 200 Areas.

\section{Operating Incidents}

In the early years of PRTR operations, lithium hydroxide, generated by the high $\mathrm{pH}$ in the primary coolant, caused corrosion that led to the failure of a mixed oxide (magnesium oxide-plutonium oxide) fuel element on August 21, 1962. This incident released about 9 inches of fuel material, including $1.8 \mathrm{grams}$ of plutonium and 15,000 curies of fission products, and caused a shutdown that lasted many weeks. During this period, the PRTR's primary system underwent decontamination from both the August 21 incident and from the overall levels of radioactivity accumulated over nearly 2 years of operations. By mid1964, however, primary system radioactivity levels, including cobalt-60 as the primary constituent, were again increasing. By September 1965, tritium accumulation in system components had become a concern, and some elevated releases of iodine-131 and xenon-133 gases occurred both within the containment area and to the atmosphere as a result of tests with predefected fuel rods.

The most significant contamination event in the PRTR's history occurred on September 29,1965 . A series of tests, designed to examine the effects of temperature increases on fuel growth, distortion, and other factors, was being conducted, using uranium oxide blended with $4 \mathrm{wt} \%$ plutonium oxide fuel. On September 29 the pinhole defect in test 17 became too hot and enlarged, releasing 705 grams of fuel (or about half of the fuel material in that rod) and bursting the process tube. The release grossly contaminated the PRTR's heavy-water moderator with fission products. Loss of materials and heavy water caused this to be listed as a Type A event under AEC guidelines. 
The heavy water was licid within the containment area, passed through ion-exchange columns for initial cleaning, and then shipped offsite for decontamination. Nearly 1 million gallons of light water were contaminated initially, but the total rose to nearly 14 million gallons as cooling water was added for many days afterward. Much of this water was taken by tanker trucks for disposal in the 200 Areas. However, as contamination levels decreased and as the capacities of disposal facilities became overwhelmed, remaining amounts of contaminated light water were disposed of in a natural depression in the ground just east of the 309 Building parking lot. Cleanup from the September 29 accident cost approximately $\$ 900,000$ and took about 6 months.

\section{Other 309 Building Missions}

Following the September 29 accident and cleanup, a major Batch Core Experiment designed to test chemical reactivity control agents was conducted in the PRTR, running for about 18 months during 1967 and 1968. In 1969 the AEC made the decision to fund breeder reactor technology at the Hanford Site (the FFTF) instead of mixed oxide fuels. Layaway of the PRTR began that year, and the reactor's irradiated fuel was processed through the PUREX plant in 1972. Today the 309 Building houses offices, shops, computer systems, and the interim examination and maintenance cell. The latter facility was built in 1975 to be an exact "cold" (unirradiated) replica of an operating cell in the FFTF and was used to train and requalify operators and to check operating procedures. The containment area under the 309 Building's dome currently is being examined for use in other testing programs.

\section{Plutonium Fabrication Pilot Plant}

The Plutonium Fabrication Pilot Plant (PFPP) (308 Building) was completed in 1960 to provide laboratories and actual fuel fabrication facilities for the development of reactor fuels containing plutonium. The first fuel mixtures produced were metallic, but ceramic fuel blends ("cermets") were being worked in the facility within 5 years. The earliest PFPP fuels were irradiated in the PRTR, the test reactor located nearby. However, the operational problems and major cutbacks in PRTR functions after 1965 caused the PFPP to seek other missions. Between 1966 and 1968, it produced neptunium-aluminum alloy fuel target elements clad in Zircaloy-2 for a plutonium-238 production test that was conducted in N Reactor. In the late 1960s lithium aluminate fuel targets with a rod-in-tube configuration and Zircaloy -2 cladding also were manufactured in the 308 Building for coproduct (tritium) production testing in $\mathbf{N}$ Reactor. From that time until the startup of FFTF test functions in the late 1970s, most fuels produced in the PFPP were irradiated in the EBR-II reactor located at the Idaho National Engineering Laboratory. Over 2,000 fuel configurations were produced in the 308 Building before 1976, many for a variety of offsite reactors.

In 1971 a high-bay addition was completed on the northeast corner of the building, containing laboratory facilities for the initial storage, handling, testing, assembly, and instrumentation of FFTF fuel. In the late 1970s a Training Research Isotopes, General Atomics (TRIGA) reactor was installed in the building to perform neutron radiography QA testing of fuel elements and fuel jackets. 


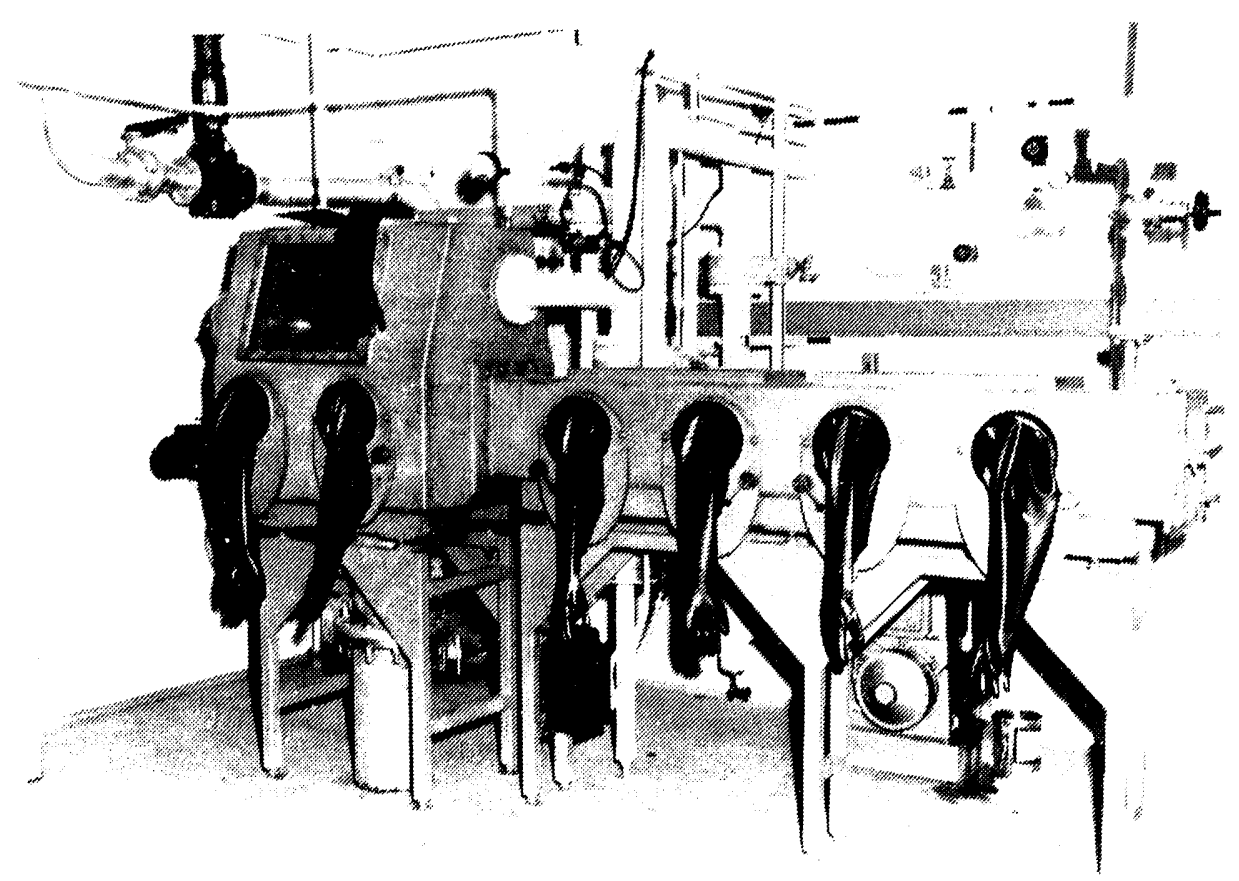

Gloveboxes for radioactive materials in the welding and auxiliary equipment room of the 308 Plutonium Fabrication Pilot Plant, new in 1959.

The TRIGA reactor sat in a double containment water tank and operated at only a 250-kilowatt power level. In 1979 a loading dock with a 10-ton-capacity bridge crane was added for handling the 8-foot-long fuel rods used in the FFTF.

Beginning in 1976 the main mission within the building became the preparation and QA testing of all FFTF fuel assemblies. This mission included the preparation of driver fuel assembly irradiation experiments performed in the FFTF, as well as tests of the first grid space assemblies for vibration-packed ("vi-pack"), high-density pellets in fuel pins. In the 1970s the 308 Building was sometimes called the Plutonium Laboratory, but the name was changed officially in the 1980 s to the Fuels Development Laboratory. Today the 308 Building is undergoing its final deactivation and cleanout.

\section{High-Temperature Lattice Test Reactor}

The main 318 Building was constructed in 1966 and 1967 to house the HTLTR, a reactor designed to test very high-temperature fuel performance in gas-cooled reactors. Near the center of the building was located the twolevel reactor enclosure with reinforced concrete walls and a reinforced concrete roof and floor. The reactor room, the ground-level portion of the reactor enclosure where the HTLTR was located, was shielded by a 50 -ton steel and high-density concrete door. A circular exit port in the south wall was provided for the flight tube of the neutron energy analyzer. A drift tube about 25 meters long extended from the reactor into an ancillary detector building located south of the reactor enclosure of the 318 Building. The 
drift tube and the neutron detector assembly were housed in this galvanized steel structure.

The reactor itself consisted of a graphite moderated core 10 feet on each side with a small, removable central section that could be adapted to various test core sizes up to a 5-foot cube. The reactor was surrounded by thermal insulation consisting of insulating firebrick, stagnant nitrogen, and a fibrous mineral blanket. This insulation, in turn, was surrounded by a radiation shield and then a gas-tight carbon-steel shell. The HTLTR operated at $1,000{ }^{\circ} \mathrm{C}$, with a maximum nuclear power of 2 kilowatts. The primary coolant was dry nitrogen gas, and the HTLTR was controlled by horizontal shutter-type control rods and gravity-drop, blade-type vertical safety rods. These rods were composed of graphite, uranium oxide graphite, and thoria-dispersed (TD) nickel. Additionally, gadolinium oxide poison shim rods, sometimes tempered with samarium, iridium, or with hafnium oxide, were loaded into varying channels of the core to control excess reactivity at room temperature and to level reactivity changes caused by temperature fluctuations during experiments. Driver fuel consisted of graphite-clad enriched (5\% uranium-235) uranium oxide ceramic pellets, and test fuels were composed of mixed oxides in pelletized or block form. The HTLTR's operations were completely computer controlled with a manual "override" feature.

\section{Building Missions}

The original 318 Building mission, that of housing, servicing, and supplying the HTLTR, was part of the fuels diversification research being carried out at HW to facilitate "peaceful atom" (Ref. 1, pp. 209-210) projects worldwide. The key functional concepts being tested in the HTLTR were high-temperature operation and nitrogen gas cooling. The experiments with mixed-oxide blend fuel rods and poison rods, as well as with different test core configurations, also were important. The high operating temperature of the HTLTR brought about many problems with reactor components and fuels. Prominent among these diificulties were thermal expansion of the TD-nickel nuts within the fuel rods, the fuel rod "boots" (flux leveling slugs occupying 4 to 8 inches on the ends of "regular" fuel rods), and the gadolinium-samarium within the control rods.

No weapons-grade plutonium or any other weapons material was researched or produced in the HTLTR. It operated from 1968 to 1972 , at which time its funds were diverted to the pursuit of breeder reactor technology. In 1973 the HTLTR's irradiated fuel rods were processed through PUREX, and its unused fuel was excessed commercially as part of a large Hanford fuel scraps cleanout program at that time. Solid nuclear wastes and spent fuel were shipped in casks to the 200 Areas for processing and/or disposal. Essentially, no serious wastes or contamination were produced. The reactor itself, along with its control room computer, was removed between 1978 and 1982.

The 318 Building has been used since that time as a service facility to house offices, computers, and work involving the calibration of dosimeters and survey instruments. It is known now as the Radiological Calibrations and Development Laboratory. The basement of the former reactor enclosure now houses an $\mathrm{X}$-ray room and X-ray control room, a photon facility, mechanical room, and several radiation source wells. The former detector building now holds one laboratory, while half of the structure is used for storage. 


\section{WHC-MR-0440}

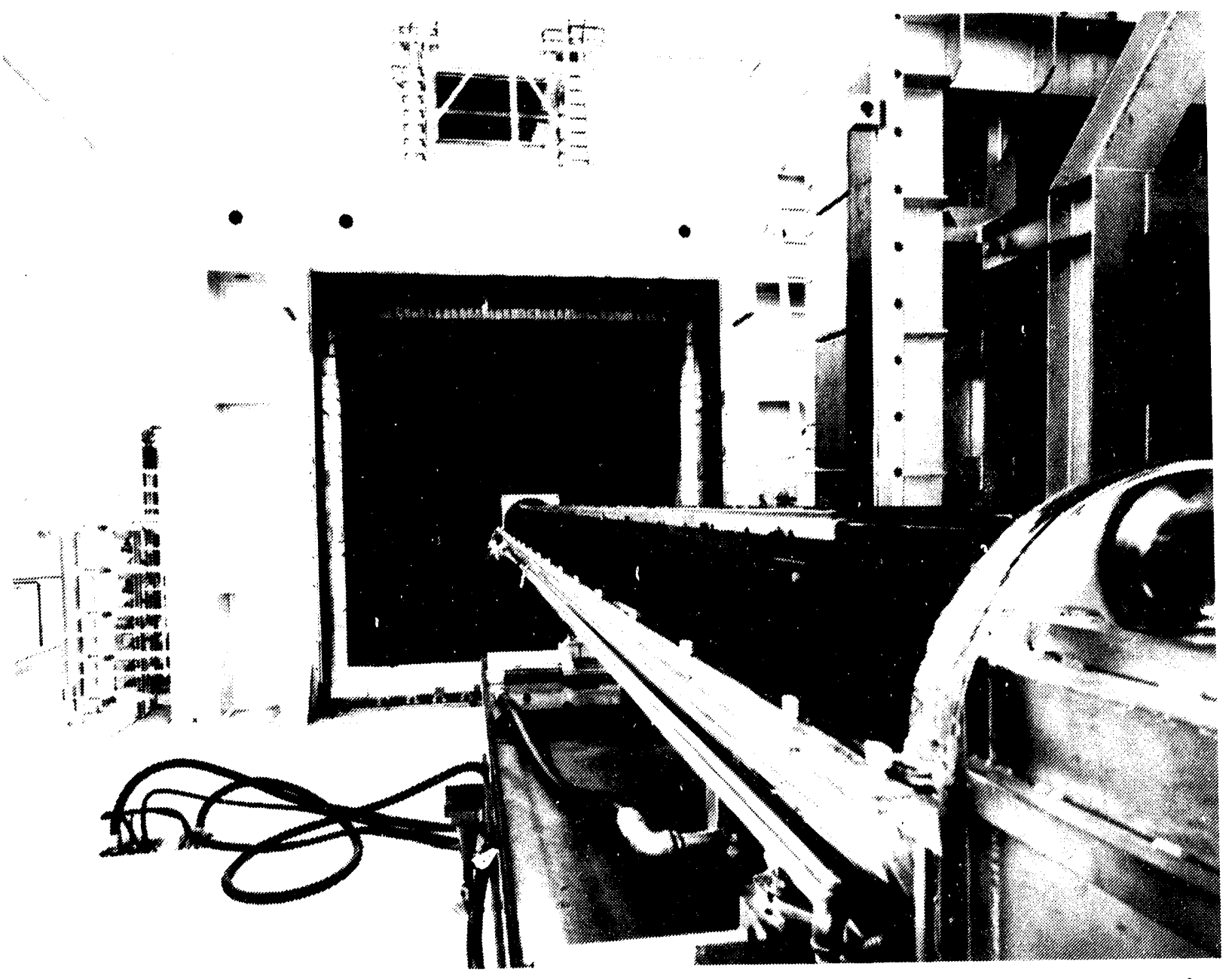

The fuel insertion assembly for the High-Temperature Lattice Test Reactor (HTLTR) in the 318 Building, 1969. 
WHC-MR-0440

This page intentionally left blank. 


\section{Modern 300 Area Buildings}

Prominent among the most modern 300 Area buildings are those that were built to support development and testing of the FFTF components and those constructed for biological and botanical research.

\section{High-Temperature Sodium Facility}

The 337 High-Temperature Sodium Facility (HTSF) was the preeminent 300 Area structure built to support FFTF development. Built in five segments from 1970 to 1972 , this huge structure originally housed engineering studies, including sodium loops and large mechanical mock-ups, plus a service area and offices. The most prominent feature of the building is a high bay that is 93 feet high abovegrade. Walls in the high-bay area consist of precast concrete panels supported by 35 tons of concrete columns, while the floor in the massive structure is rated to hold $250 \mathrm{lbf} / \mathrm{ft}^{2}$. A 25-foot-diameter, double-steellined concrete caisson begins 20 feet belowgrade and extends 60 feet belowgrade in the high-bay area. Additionally, an 8-foot-diameter unlined concrete assembly pit begins 20 feet belowgrade and extends to 35 feet belowgrade, with a shaft penetrating down another 13 feet. The facility originally housed a 50-ton-capacity bridge crane and later a 100-ton-capacity bridge crane, to handle replicas of giant FFTF equipment.

\section{Alphabet Soup of FFTF Parts Tested}

The initial research and development activities housed in the high-bay area included a Core Mechanical Mock-up, an accessible test bed for operational trials of selected FFTF components in an air environment. Among the earliest components mocked up and tested were the In-Vessel Handling Machine, the Instrument Tree, and the Control Rod Drive Lines. Another original research function performed in the high bay was known as the Composite Reactor Components Test Activity. This test facility experimented with FFTF components in the actual operating environment that included the argon cover gas and molten sodium coolant. The Prototype Closed Loop Development Installation also provided a test bed to verify final design, operability, and maintenance capability for the FFTF's closed loop. By 1974 an Alkali Metals Cleaning Facility was added in the high bay to develop methods to react sodium off of mechanical components without damaging underlying materials. All of this testing was done on "cold" materials.

Additional FFTF developmental missions performed in the 337 Building included the invention of the pioneering gas-tagging system that attached a unique identifying gas to each fuel assembly or experiment. Gas tagging gave FFTF operators a ready means of locating breaches in fuel elements by periodic gas sampling. Sodium purification and cover gas purification methods for the FFTF also were developed in the 337 Building. Closed loop, in-reactor assembly fabrication work was done, as was the Postirradiation Open Test Assembly project and a Solar Demonstration Project. In 1977 all sodium loops and other FFTF components work was deactivated. During 1990 and 1991, equipment was brought into the high bay for a Robotics Technology Demonstration project important in developing safer and more accurate means 


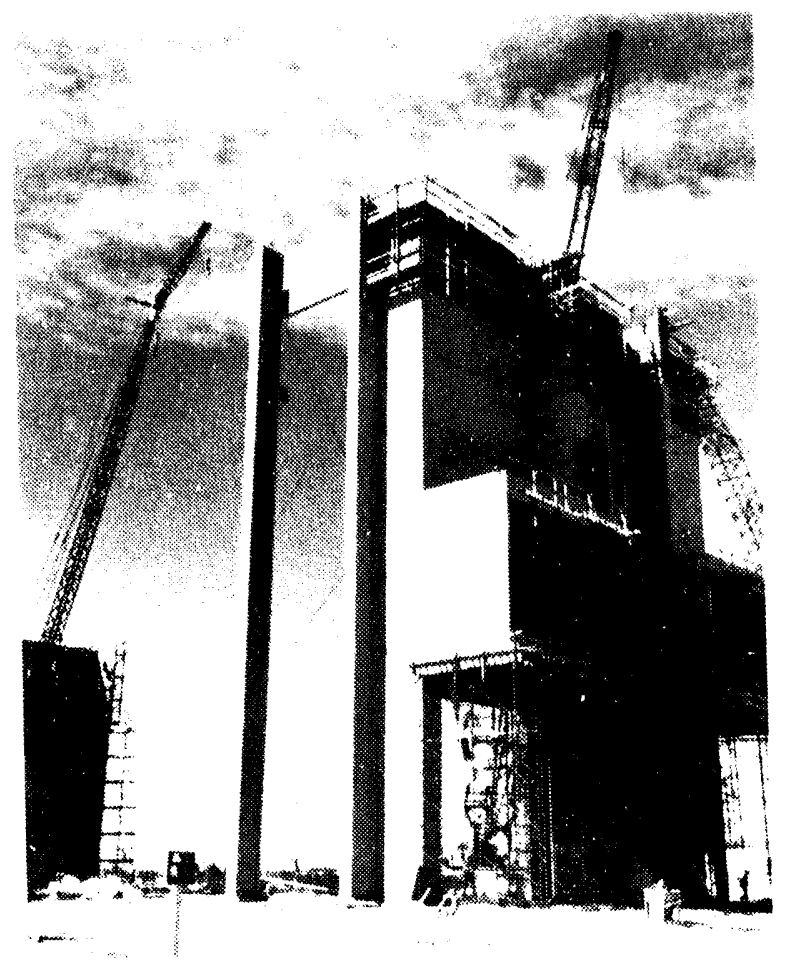

Left, the high-bay portion of the HighTemperaiure Sodium Facility (HTSF). 337 Building, under construction in 1969.

Below, aerial view of the newly completed High-Temperature Sodium Facility, 1970.

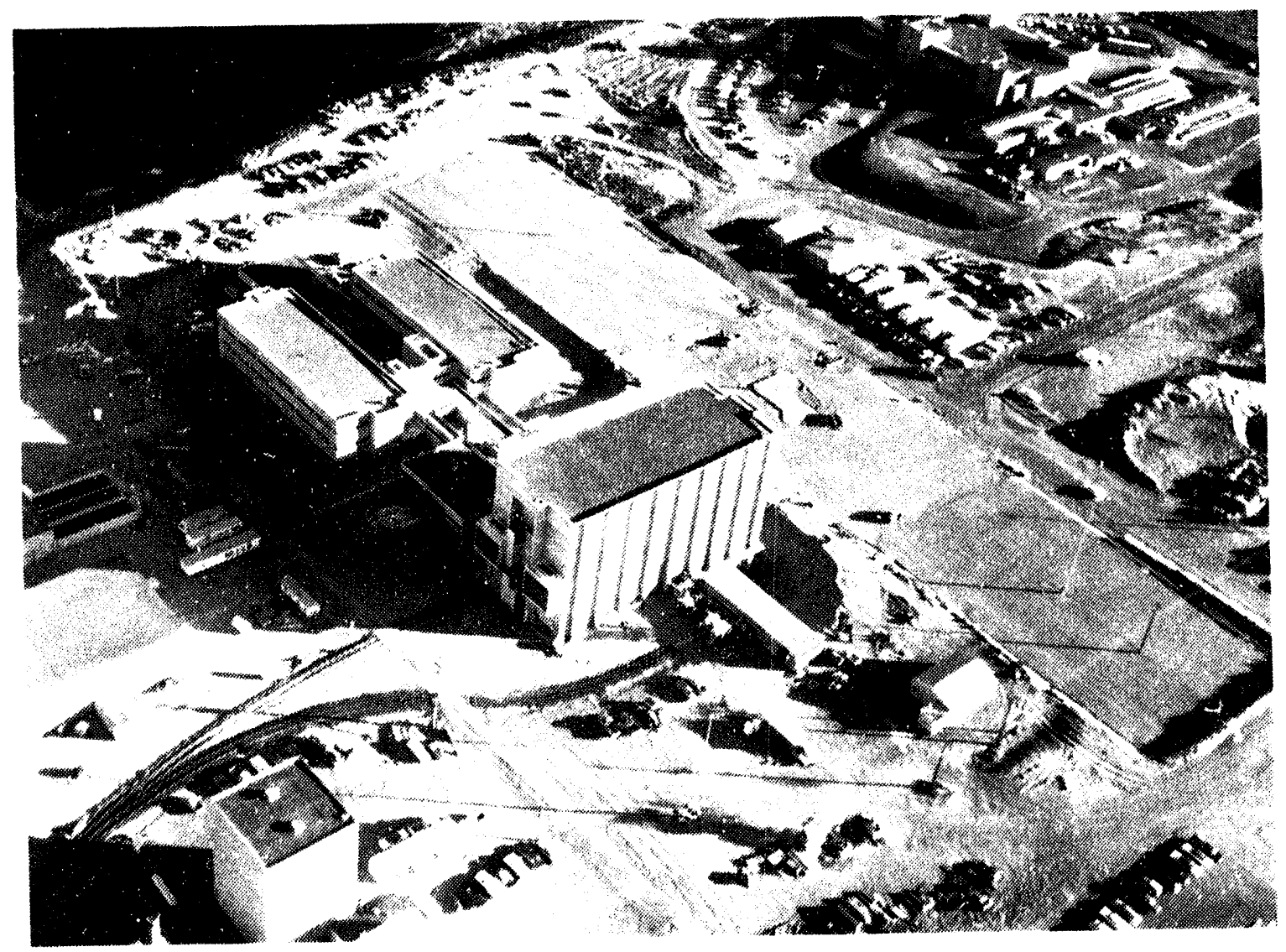


of performing in-cell and in-reactor operations. Mock-up and test equipment to be used in Hanford Site tank waste remediation projects may be emplaced in the high bay in the future.

\section{5 and 336 Sodium Test Facilities}

The 335 and 336 Sodium Test Facilities were constructed to house experimental equipment for the study of the properties of sodium and the behavior of mechanical components to be operated in a sodium environment. In actuality, many of the experiments were conducted with a sodium and potassium mixture with properties very similar to pure sodium. The small 335 Building, known initially as the Fast Reactor Thermal Engineering Facility, was completed in 1968, while the 336 Building, smaller yet but tall (65 feet high), was completed in 1969 as the Core Segment Development Facility. It housed a cold sodium purification and characterization system used in FFTF developmental studies.

The 335 and 336 Buildings functioned in their original roles of containing sodiumrelated tests for FFTF development through the late 1970s. In 1977 the sodium test loops were deactivated, and they were removed during 1983 and 1984. Eddy current flowmeter calibration equipment (for use by fuel fabrication facilities) was installed in the 336 Building in 1977 . In 1984 building modifications began in preparation for its use as a cold mock-up area for the extraction portion of a tritium production program being planned for $\mathrm{N}$ Reactor. However, funding was cut from that program before the modifications were complete. In 1987 the 335 Building was identified for use as a computer facility in the Basalt Waste Isolation
Project operation, but the termination of that program in December 1987 precluded this use. Today it is known as the Radionuclide Logging System Laboratory. The 336 Building is known as the Fuels Dynamics Laboratory.

\section{Components Mock-up and Maintenance Facility}

The 338 Building, originally a 100-F Area structure, was moved to the 300 Area in 1971 to receive, mock-up, test, and store components and certified materials for use in the HTSF. A very heavy concrete main floor was emplaced, with a loading capacity of $250 \mathrm{lbf} / \mathrm{ft}^{2}$, along with a pit 33 feet deep. Room 100 on the main floor, known as the Operations Center, had a raised floor with a loading capacity of $1,000 \mathrm{lbf} / \mathrm{ft}^{2}$.

The 338 Building served in its initial functions of varied FFTF equipment support activities through the early 1980s. In 1978 it was evaluated as a possible location for the HCVF, a cold mock-up of a processing cell in the FMEF (427 Building), but this mission went to the 321 Building. Instead, a Remote Maintenance Evaluation Facility was emplaced in the 338 Building. By 1981 FFTF developmental work had diminished greatly, and the 338 Building was converted that year to house the Secured Automated Fabrication (SAF) Cold Test Facility, a nonradioactive demonstration project for oxide fuel processing line operations for the FMEF. In 1983 the north end of the building was considered as a place to house an equipment development and operator training project for the PUREX Facility Modification Program (PFMP). However, the PFMP mission went to the 305 Building instead. During 1985 and 1986, SAF equipment was removed from the 338 Building, and in 1988 the facility was 


\section{WHC-MR-0440}

converted to a chemical and hazardous materials storage area. A roofed concrete pad was installed on the northeast corner for this purpose. Today, the 338 Building is known as the Maintenance Building and serves as a less-than-90-day storage facility for hazardous materials.

\section{Life Sciences Laboratory and Ancillary Buildings}

The 331 Life Sciences Building, constructed in 1970 to replace the old HW Biology Laboratory (108-F Building), is a large reinforced concrete structure that originally contained many laboratories. Among these were a multiroom inhalation toxicology exposure suite that held plexiglas * animal exposure chambers and related metabolism rooms; an irradiation room, holding a cobalt-60 source; an electron microscope suite; and laboratories devoted to dosimetry, isotope preparation, plant physiology, terrestrial ecology, aquatic biology, and biochemistry. Additionally, small animal facilities and related animal physiology and inhalation toxicology laboratories; low-level and high-level radiochemistry laboratories; as well as tissue culture, virology, histology, hematology, biochemistry, histochemistry, pathology, and microbial physiology laboratories were located in the building. Support facilities included a counting room; change rooms; receiving area; instrument, mechanical, and electrical equipment rooms; maintenance shops; central glassware washing facilities; special instrument and equipment rooms; controlled temperature rooms; and aquatic biology head tanks and their related mechanical and water treatment equipment rooms.

Two smaller ancillary structures labelled the 331-A and 331-B Buildings accompanied the original 331 Building. The

331-B Building, located just southwest of the main building, had a long narrow animal run attached to it. The run area originally contained 110 concrete living units for dogs, as well as four laboratories, including an animal clinic, hospital, food preparation room, and change room. The original 331-A Building, located just northwest of the 331 Building, contained 15-pen areas for large animals (originally swine), as well as three laboratories and a mechanical equipment room. Together, the 331-A and 331-B Buildings were known early as the "hog and dog runs."

\section{Complex Additions}

In 1972 the small metal 331-C Building was erected on a concrete slab south of the 331 Building to serve as a storage warehouse for 331 Complex needs. During 1973 and 1974 the 331-D Building, a semihigh bay, prefabricated, metal building was erected on a concrete slab to the southeast of the 331 Building to serve as the Animal Waste Treatment Facility. It operated to chemically treat, mechanically floccuiate and settle, and then gravity filter animal wastes. A sludge dryer also was installed to heat and dry sewage sludge product from the treatment facility and to produce a solid waste material that could be buried in trenches in the 100 and 200 Areas. This treatment facility was needed because hog hairs, sawdust, and undigested animal feed frequently plugged the unlined animal waste pit then in use along the Columbia River.

"Plexiglas is a trademark of Rohm and Haas. 


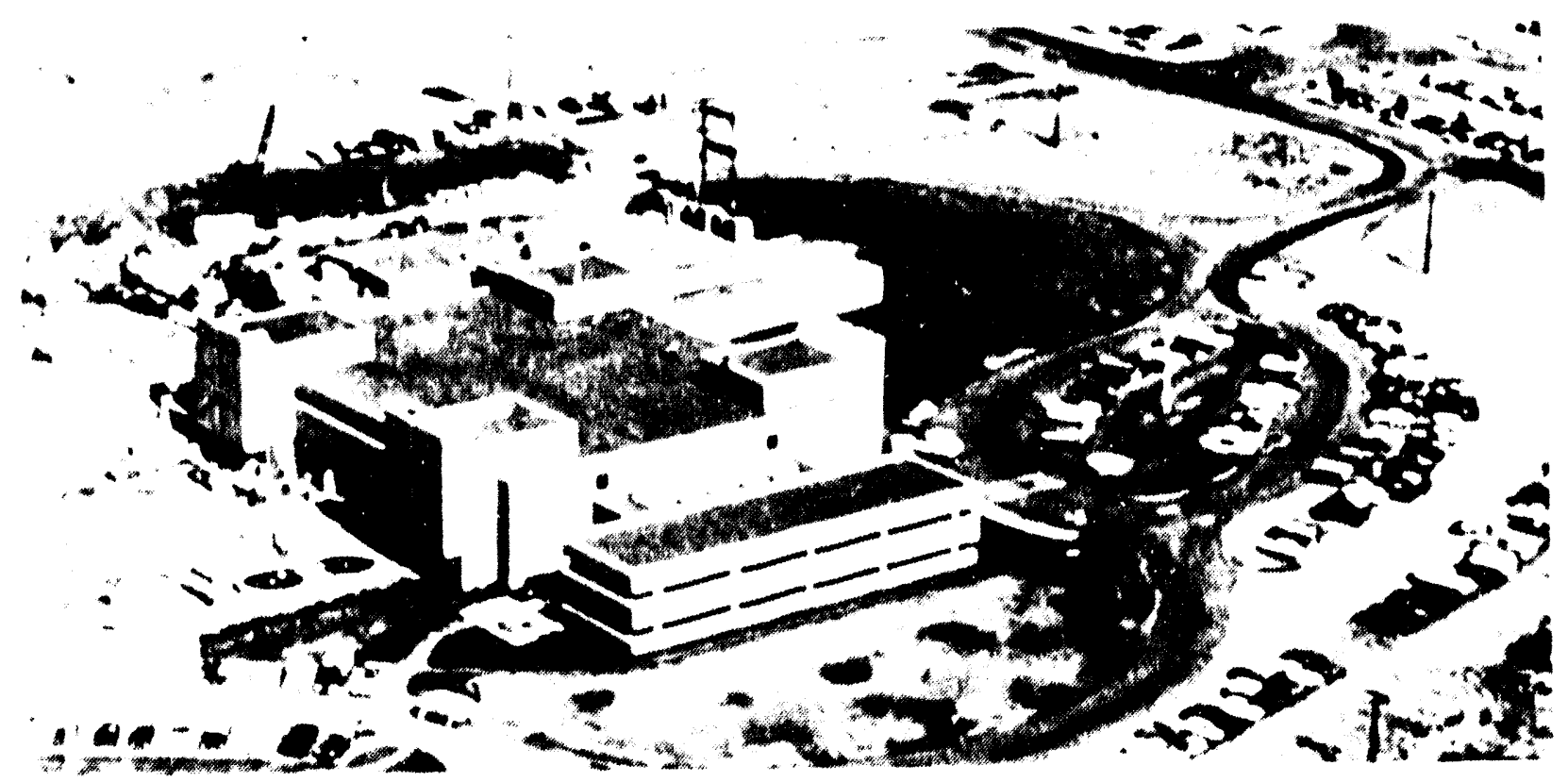

The 3.31 Life Sciences Building, nearly complete in early 1972. The building's many ancillary facilities stretch to the south (left) out of sight.

The 331-E greenhouse, constructed in 1975 , was built to provide an environment in which to grow plants for ecosystem studies.

The 331-F Building, previously the 142-F structure, was moved to a location southwest of the 331-E Building in 1975 to provide storage space for equipment and materials used in animal and pasture maintenance. At the same time a new, 18-acre pasture was built at the south end of the 331 Complex. It contained 12 animal shelter units, erected in pairs on concrete pads. Also in 1975, the concrete block 331-G Farrowing Facility was constructed just east of the $331-\mathrm{F}$ Building to house laboratory animals (specifically swine) while they were giving birth. In 1979 the 331-H Plant Exposure Facility was constructed just north of the 331-F Building. The following year a metal lean-to, containing a wind tunnel room, a growth chamber alcove, two air locks, and mechanical and equipment rooms, was attached to the northwest corner of this structure. It housed an exposure test chamber to study the effects of various aerosols and actinide elements on plants. In 1984 the 331-J Hay Storage Barn was erected just east of the 331- $\mathrm{H}$ Building.

\section{Complex Missions}

During its initial years of operation, the 331 Complex conducted plutonium inhalation studies on dogs, plutonium injection studies on rats, cigarette addiction and effect studies on monkeys, and research leading to new heart surgery techniques and hip replacement surgery capabilities on goats and other animals. Experiments with the effects of radiation exposure on hair and skin were conducted on swine, and a miniature (160-pound average) hairless strain of swine was developed for this purpose in the 331 Complex. Extensive aquatic biology studies, including gill disease research, also 
were performed, with up to 800 gallons per minute of Columbia River water pumped through large-capacity tanks in the main 331 Building during the years 1971 to 1975. A small number of sheep were kept at the 331 Complex for research purposes in the mid-1970s, but then these studies were phased out completely.

In the years after 1983 life sciences studies were cut sharply, and several of the buildings assumed new functions. The 331-A Swine Facility was converted in the early 1980 s to a virology laboratory for the study of bacterial and viral growth in animals. The 331-D Animal Waste Treatment Facility was converted in 1977 to a biomagnetic effects laboratory, where electromagnetic field studies were conducted on rats. The 331-J Hay Storage Barn was enlarged, and a new incinerator was installed about 1988 to cremate animal remains. In 1989 the Hanford Cultural Resources Laboratory (HCRL) was moved into the main 331 Building to conduct archaeological surveys and preservation work concerning native American and other prehistoric artifacts on the Hanford Site, but HCRL offices have since moved. Some longterm experiments involving dogs continue, but the number of laboratory dogs being studied has diminished from the original figure of nearly 600 . Aquatic biology experiments, likewise, have diminished dramatically. Some plant studies continue in the 331 Complex, but other botanical work and some cattle studies now are conducted at the Arid Lands Ecology reserve on and near Rattlesnake Mountain. At this time the 331 Building also houses Pacific Northwest Laboratory's Earth Sciences department, and the Hanford Site patrol guard dogs are kenneled in the 331-B Building animal run area. 


\section{Significant Miscellaneous Buildings in the 300 Area}

\section{Gamma-Neutron Irradiation Facility}

The 3730 Building was constructed in 1949 as an unnamed "steel building" to house fabrication operations for specialized graphite shapes. The structure also stored uranium turnings and contaminated materials, including ruptured fuel slugs waiting for analysis in other structures.

During 1955 and 1956 it received a new roof and a concrete vault addition. At that time, the structure was named the Graphite Laboratory and Shop but termed the "Hot Shop" by HW workers. The new modifications enabled it to better house the examination, study, and storage of irradiated graphite samples from the 305 Test Pile and the 100 Areas production reactors. Th: 100 Areas reactor closures and the cessation of 305 Test Pile operations at $\mathrm{HW}$ in the late 1960s almost completely ended the need for traditional 3730 Building functions.

At that time the emplacement of a 350,000 -curie, cobalt- 60 source in a waterfilled pit beneath the building changed the facility mission to that of instrument measurements and stress corrosion testing of nuclear waste container materials. Parts, gaskets, electrical cables, and other materials with potential use in hot cells or in geologic waste repositories also have been tested in the 37 stainless steel tubes of this gamma irradiation test facility. In the early 1970s a long-term leak began in the cobalt-60 source, which was not detected until 1974. By that time, leakage through liquid pathways had contaminated the 300 Area Process Ponds, sanitary sewer lines, manholes, and groundwater near the 3730 Building. Repairs were made from 1974 to 1976 , and in 1980 gloveboxes used for the examination of irradiated fuel coupons were added to the facility.

\section{Shop Building Filled Widespread Needs for Hanford Laboratories}

The 328 Engineering Services and Safety Shop, called the Mechanical Development Building when it was constructed in 1952, was built to contain craft, equipment, and fabrication services for the 300 Area laboratories. The building did not serve the fuel fabrication facilities but instead housed fabrication and servicing of specialized and intricate apparatus and equipment needed by the chemistry, physics, biophysics, and metallurgy laboratories.

The 328 Building was constructed to replace the wartime 3717 Instrument Shop and the two 3722 Area Shops rendered obsolete in 1952 by the specialized needs of radiochemistry, radiometallurgy, and physics laboratories. The inclusion of a "well-equipped" (Ref. 6, p. 41) central shop in the 300 Area expansions of 1952 and 1953 was termed "mandatory" (Ref. 6, p. 41) by HW planners. The construction of the 328 Building allowed designers of the 


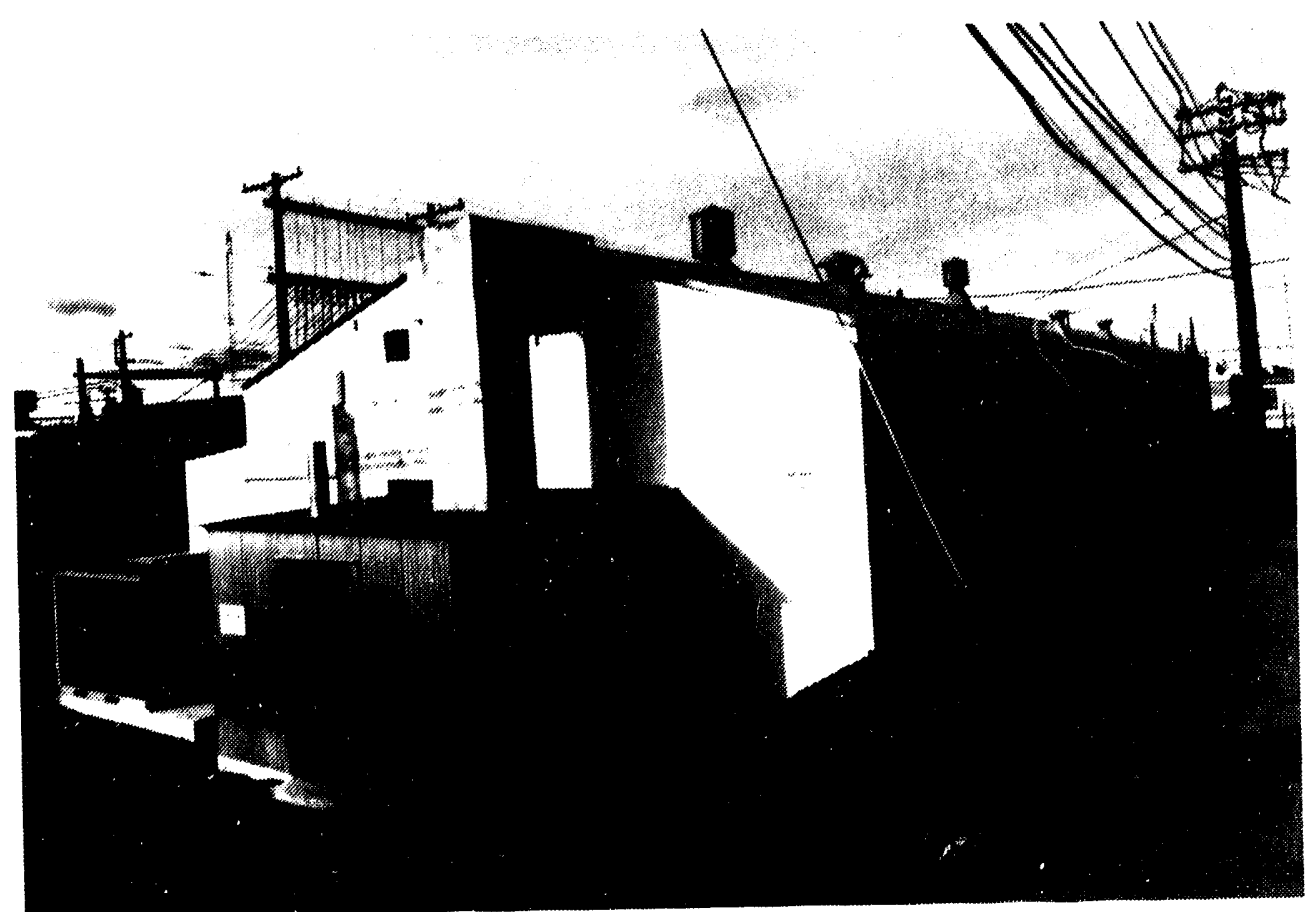

The 3730 Gamma-Neutron Irradiation Facility, shown in 1982.

specialized $325,326,327$, and 329 Buildings to reduce the shop facilities in these structures to "the minimum required for repairs to contaminated equipment not permitted to leave the 'hot' buildings." (Ref. 6, p. 41) The 328 Building was a cold facility not equipped or permitted to contain radioactive materials. It housed a main metal and machine shop; two mock-up shops; a drafting room; as well as welding, paint, carpentry, and glass-blowing shops. The large shop contained a spark erosion machine for cutting conductive metal, controlled atmosphere heat trating equipment, metallizing and hard chrome plating apparatus, a paint spray booth, and hooded facilities for working with quartz.

In 1961 a large annex known as the 328-A Building was added to the

328 Building. Over the year the functions of these facilities changed very little. During the 1960s they became known as the Engineering Management and Technical Shop, and then later the present name was adopted. The building still contains specialized and general equipment fabrication and repairs for Hanford Site laboratories, although it does not house glass blowing, optical, or instrument calibration work.

\section{Waste Technology Engineering Laboratory}

The large and complex 324 Building was constructed from 1964 to 1966 as a Fuel Recycle Pilot Plant. It was designed partially to support PRTR operations by housing chemical reprocessing and metallurgical examination on the PRTR's fuel elements. As such, it was built as a dual facility with both radiochemical and radiometallurgical hot cells and laboratories. It also was designed to house the Waste Solidification Engineering Project (WSEP), one of the first high-level 


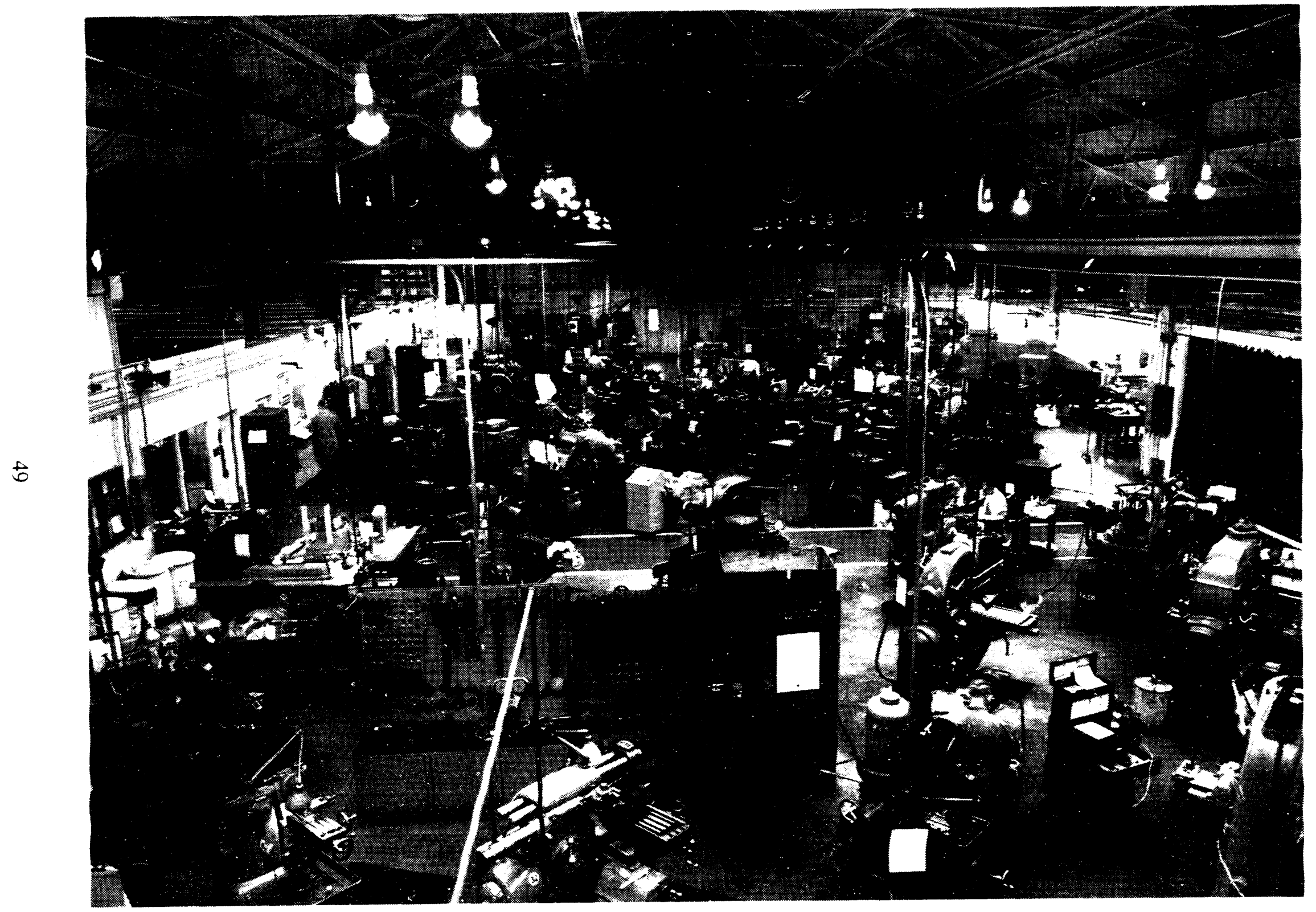


waste vitrification demonstration programs in the world. However, mission changes caused the facility to be known as the Chemical Materials Engineering Laboratory throughout most of its history.

The radiochemical portion in the north side of the building was built with four large hot cells (A-, B-, C-, and D-Cells), along with an Air Lock Cell. All of these cells were contained by high-density concrete walls and at least partial stainless steel liners. A-Cell contained the Waste Canister Storage Engineering Test Facility, consisting of 6 cubicles in the north wall. B-Cell was the largest at 25 feet by 22 feet by 30.5 feet deep (three stories). The southeast section of the 324 Building contained the Radiometallurgy and Materials Testing Laboratories, including three large hot cells known as the Shielded Materials Facility (SMF). Among these, South Cell was the biggest at 16 feet by 50 feet, and it contained its own 3-ton bridge crane and five compartments.
In addition to hot cells, the 324 Building contained many other laboratory facilities. Among these were four Engineering Development Laboratories (EDLs), two designed for work with nonradioactive materials and two designed for hot work. The original construction of the 324 Building also included a high-bay truck lock and rail loadout station, located on the north side of the building. Adjacent to this truck and rail lock was the Cask Handling Area that contained a small facility equipped with manipulators and a remote viewing window used to transfer highly radioactive solutions between shipping casks and shielded facilities casks. A large basement area within the 324 Building was known as the Safeguards Vault and Laboratory Area. It contained four laboratories; three facilities connected with shipping and packaging; various tanks; and the Fissile Materials Storage Vault, a 1970 addition, which received extensive modifications in 1975. Located beneath the SMF cells, this vault was topped with concrete and lead

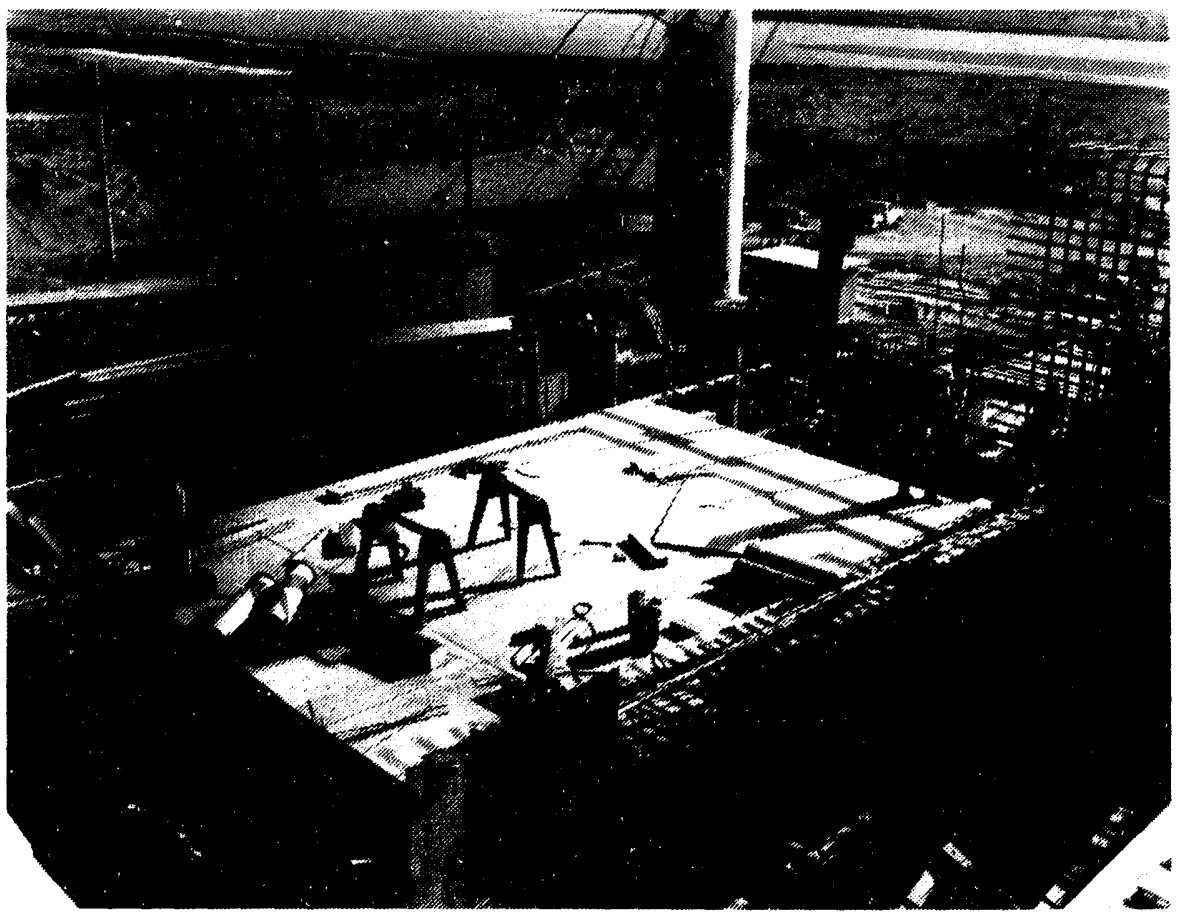

The original 324 Fuel Recycle Pilot Plant, showing a hot cell under construction, 1964. 


\section{WHC-MR-0440}

shielding. It had a 4-hour fire-rated metal door and contained 12 fissile-material storage cabinets arranged in a diamond array and further separated by two concrete pillars. It also held a freezer for the storage of highexposure plutonium. Before the storage cabinets and freezer were emplaced, the vault served as the location of HW's earliest sodium loops to perform corrosion, deposition, and other testing for FFTF development. Handbuilt lead brick caves containing portable lead glass windows were installed for this work, and irradiated iron alloys were exposed to flowing liquid sodium.

Three additional basement chemistry laboratories were located in the 324 Building, along with a general purpose cold laboratory on the first floor and four second-floor chemical engineering laboratories. There also was a large maintenance and fabrication shop in the west end of the building. Additionally, the 324 Building had a High-Level Waste Vault containing eight tanks and a Low-Level Waste Vault containing four tanks. These vaults were located belowgrade on the north side of the building.

\section{Building Missions}

Almost as soon as the 324 Building was completed, the PRTR operating accident of September 1965, combined with the AEC decision to emphasize breeder reactor research, signalled an end to the 324 Building's PRTR support work. Waste Vitrification (WSEP) work began in the radiochemistry cells in "solidification units," including a large platinum melter and a titanium concentrator located in B-Cell. Extremely high-level waste, sometimes "spiked" with extra strontium-90, was used as the feed material until the mid-1970s, when spent commercial reactor fuel began to be used. Vitrification continued as a major radiochemical mission in the 324 Building until 1980. During the early 1980s radiochemistry work included the solidification, encapsulation, and packaging of spent ion-exchange resins from the Three Mile Island (Pennsylvania) reactor and the pilot testing of Radioactive Liquid-Fed Ceramic Melter operations. Cesium heat source manufacturing for the Federal Republic of Germany was the major radiochemistry program underway in the building from 1986 to 1990 . Additionally, bioremediation techniques were investigated, and hightemperature melters were used to experiment with the treatment of medical and other radioactive wastes.

Radiometallurgical programs in the 324 Building have centered on the NDE of irradiated fuel elements and other irradiated structural materials, including reactor process tubes. The large capacity of the SMF cells made them capable of handling the longer fuel elements from reactors, such as the PRTR (88-inch fuel elements), the EBR II, and the FFTF (8-foot fuel elements). Between 1968 and 1980 gamma ray scanning, profilometry, and other types of NDE were conducted on fuel elements from these reactors, and some reconstructive work (reassembly of breached fuel pins) also was conducted. Since 1980 the SMF cells have processed at least one Materials Open Test Assembly from the FFTF each year and have tested, reassembled, and stored many irradiated fuel elements and structural components. During 1991 and 1992 capsules containing cesium chloride were pressed and assembled in South Cell for a commercial medical isotopes company. Today Hanford Waste Vitrification Plant engineering verification and process verification missions are important parts of the 324 Building work.

Additionally, important sodium work has been performed in the 324 Building. After the 337 Building was completed in 1971, the sodium testing loops were removed from the 


\section{WHC-MR-0440}

324 Building's Fissile Materials Storage Vault area. However, a Sodium Removal and Decontamination Apparatus then was installed in one of the EDLs to perform sodium decontamination testing on various irradiated metallic coupons. Other liquid metal studies, including caustic stress corrosion testing, electropolishing, and cesium absorption experiments, also were conducted in this EDL and in several laboratories. Sodium decontamination and a Sodium Ethanol Cleaning System also operated in and near the building in the 1970s.

\section{Low-Level Radiochemistry Building}

The 320 Low-Level Radiochemistry Building was built in 1966 as virtually the last facility in HW's postwar defense construction. The original basement and ground floor levels both received a large addition consisting of four laboratories and eight offices in the early 1980s. Twenty-two laboratories were located in the structure, including several devoted to wet chemistry, a large radiochemistry laboratory, an analytical research and development laboratory, and a heavy element chemistry laboratory, all on the first floor.

The 320 Building's original mission, conceived 15 years before the facility was constructed, was to house analytical chemistry services and plant support for many HW groups and departments in work involving low-level and nonradioactive samples. It was recognized that metallurgy and physics groups would need a broad range of chemical analyses, including the testing of graphite and various other reactor materials for impurities; the testing of uranium and uranium alloys for "a great variety of constituents in a wide range of concentrations" (Ref. 6, pp. 79-80); the sampling of pile (reactor) gases, organic compounds, metals other than uranium, acids, bases, and salts; and the analysis of multifarious production test results. Additionally, wrote early postwar HW planners, "a large plant such as the Hanford Works requires regularly the analysis of a large number of miscellaneous samples... [among which are] oils and greases, paints and related products, other protective coatings, unknown materials submitted for identification, corrosion product identification... gas analysis... biological and pathological samples, comparisons of materials from prospective vendors, materials of construction... steel analysis [and] physical testing of numerous materials for quality comparisons." (Ref. 6, pp. 79-80) To save the use of laboratories equipped to handle hot samples for specialized chemistry, physics, and metallurgy work, a low-level radiochemistry and "plant assistance" building was included in overall plans. However, budgets and other higher priorities prevented the construction of such a facility until the $1960 \mathrm{~s}$.

The original work performed in the 320 Building included gamma ray spectrographic analysis, physical measurements with instruments, and various types of radiochemical separations processes similar to those performed in the 325 Building but involving samples with low levels of radioactivity. Among these processes were solvent extraction, ion exchange, carrier precipitation, and electrodeposition. Some analytical support also was provided to environmental monitoring and bioassay samples, again on materials with lower radioactivity levels than those analyzed in the 329 Building. 


\section{WHC-MR-0440}

Virtually, as soon as the 320 Building was completed, production cutbacks overtook HW. To diversify and expand the facility's work, Hanford planners took on a great many assignments from offsite. Additionally, a number of basic research programs were started. These projects resulted in the development of several pioneering techniques in the building, including radiometric techniques, new mass spectrometric

techniques, combined (simultaneous) atomic absorption/mass spectrometric analysis, and laser-based spectrometric techniques. Recent missions have included radiochemical environmental analyses, sample preparation, methods development, and many classified programs that cannot be described. The facility now is called the Analysis and Nuclear Research Building. 
This page intentionally left blank. 


\section{Area Process Waste Handling and Disposal}

\section{Liquid Wastes Disposed of to Process Pond}

The original 300 Area process sewer system, built by MED and duPont during World War II, routed industrial wastes through an underground piping network to a single Process Pond located along the Columbia River just north of the coordinates of the 313 and 314 Buildings. The original pond was about 490,000 square feet and approximately 5 feet deep. Throughout the early years of 300 Area operations, radioactivity levels in the main Process Pond rose precipitously, climbing by three to thirty orders of magnitude in water and mud samples taken from 1945 through 1948. These increases, along with a spike in pond contamination readings in September 1947, resulting from a large release of uranyl nitrate hexahydrate (UNH) from the 321 Building that month, led to the decision to build the 300 North Cribs (also known as the 321 Cribs) about 5 miles north of the 300 Area. These cribs, constructed in the spring of 1948, consisted of two inverted stainless steel tanks buried above gravel and substrata. They allowed UNH, ammonium nitrate, hexone, and other solvent wastes to percolate into the ground. These cribs received liquids containing about 2,070 pounds of uranium between 1948 and 1956.

On October 25, 1948, the 300 Area Process Pond dike broke on the northwest side, releasing the bulk of pond contents to the Columbia River. The HW monitoring reports estimated that 12 to 61 pounds of uranium contained in 14.5 million gallons of waste overall was discharged to the river in 90 minutes. An increase in the liquid level in the pond, resulting from the plugging of the earthen bottom with a clay-like uranium/aluminum hydroxide mixture (sodium aluminate), was blamed for the break.

\section{Second Process Pond and 307 Trenches Built}

Following this dike a new and larger Process Pond was built north of the older pond, and the first pond was soon dredged and returned to service. Thereafter, the two facilities were known as the North Process Pond (newer) and the South Process Pond (older). Periodic dredgings of the bottoms of both ponds then were conducted over the years, with the dredged material piled on the dikes to strengthen them. By 1955 so much uranium-bearing sludge had built up on the bottom of the North Process Pond that the facility was taken out of service for 14 months and dredged. Uranium (10,300 pounds) was recovered out of sludge deposits up to 9 inches thick in this pond.

In 1953 two 307 Trenches were constructed just north of the present location of the 324 Building. Active until 1963, these trenches received liquid waste and sludge from the South Process Pond totalling approximately 11 tons of uranium, 13,200 pounds of lead, 6,600 pounds of nickel, 4,400 pounds of fluoride, 2,200 pounds (each) zinc and chrome VI (hexavalent chromium), and other heavy metals and chemicals.

\section{Modern Trenches and Disposal Practices}

The North and South Process Ponds were phased out of service in 1974 and 1975. 


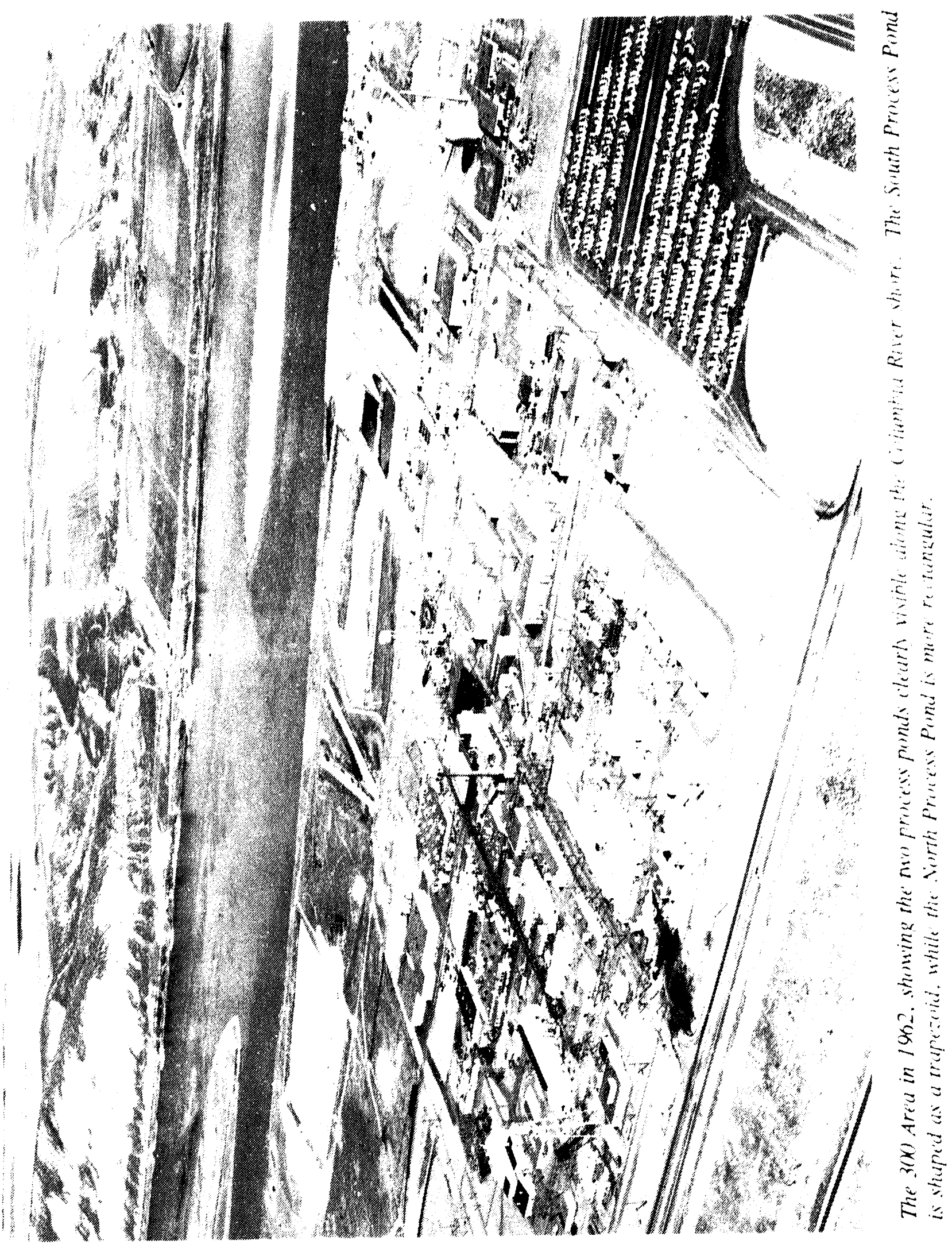


During the same years, two 300 Area Process Trenches (the West Process Trench and the East Process Trench) were constructed on a north-south axis just north and west of the old Process Ponds. Since then, 300 Area process wastes have gone to these 1,500-foot facilities for slow percolation into the ground, to the 183-H Solar Basins for evaporation (until 1985), or into the WATS process. Most offstandard releases to the process sewer system since 1975 have involved WATS failures or operational problems.

Liquids and particulates in solution disposed of in the 300 Area Process Ponds and Process Trenches over the years included all of the metallic and chemicai components of the fuel fabrication process and all of the separations process chemicals and solutions used in 3706 Building and 321 Building tests of the bismuth phosphate, REDOX, Metal Recovery, PUREX, and RECUPLEX processes. Chemicals used in bioassay and environmental sample analyses also contributed a much smaller portion of 300 Area process wastes. Soils, groundwater, and the Columbia River shore in, beneath, and near these ponds and trenches have become contaminated with the above substances. Additionally, pronounced uranium-bearing liquid waste plumes were tracked in the Columbia River flowing past Richland in 1957 and 1962. Some settled solids from that waste stream may still be encountered in the riverbed along the west shore and in drains, pipes, pipe trenches, and sewer manholes in the 300 Area.

In 1987 the weir box at the south end (entry) of the 300 Area Process Trenches was cleaned out and sifted. Solids and rocks were buried in the 200 Areas, and samples of the remaining sludge were found to contain $2.58 \%$ uranium, along with slightly lower concentrations of calcium, iron, and trace amounts of other substances. Eventually 911 pounds of uranium were recovered from this sludge. In a 1991 Expedited Response Action, the Process Trenches were partially remediated to remove contamination prone to leaching further into the ground and the Columbia River. In 1993 ground was broken for an effluent treatment disposal facility at the north end of the Process Trenches. Scheduled for completion by December 1994, this facility will receive process liquids directly from building transfer pipes and will treat up to $\mathbf{4 0 0}$ gallons per minute by carrier precipitation, filtration, and carbon and ionexchange columns.

\section{Complex and Radioactive Liquid Waste System Bring Changes}

As part of a very large defense production expansion that occurred in the HW's 300 Area in the period from 1951 to 1953 , a new system was constructed in an attempt to deal with radioactive effluents from several laboratories in a modern, controlled manner. The 340 Retention and Neutralization Building, along with the 307 Basins, was equipped to sample and then disposition liquid wastes piped from 300 Area laboratories. If radioactivity was not detected above release limits, these wastes were disposed of to the 307 Trenches. If levels proved to be above release limits, the effluents were pumped into the 340 Building tanks and then trucked to the 200 Area disposal facilities (usually cribs). The sampling and holding tanks in the 340 Complex were fed by the Radioactive Liquid Waste System (RLWS), a network of single-walled stainless steel pipes buried at slightly varying levels approximately 20 feet belowground and also from the Retention Process Sewer, also known as the Diversion Waste System. In 1960 the new 308 and 309 Buildings were completed, and both were connected to the 340 Building via RLWS pipes. In 1964 the new 324 Building also was connected. 
Modernizations of the $\mathbf{3 4 0}$ Complex and the RLWS took place over time. In 1965 the 340-B Rail Load-out Facility was constructed so that shielded rail cars could be substituted for tanker trucks in the transport of radioactive effluents from the 340 Tanks to the 200 Areas. During 1978 and 1979 the entire RLWS piping network was replaced with double-walled stainless steel pipes, a leak detection system, many new valve boxes, and other system parts. The old RLWS pipes were abandoned in place, and portions of soil contaminated by their leaks still remain. At the end of this period, other policy changes and equipment upgrades designed to reduce radiation exposures in and around the 340 Complex were instituted. A batch control policy was implemented beginning in 1979, and the following year new charcoal filters, HEPA filters, exhaust fans, and improved instrumentation and pumps were added. Further instrumentation upgrades were added in 1986 and 1987.

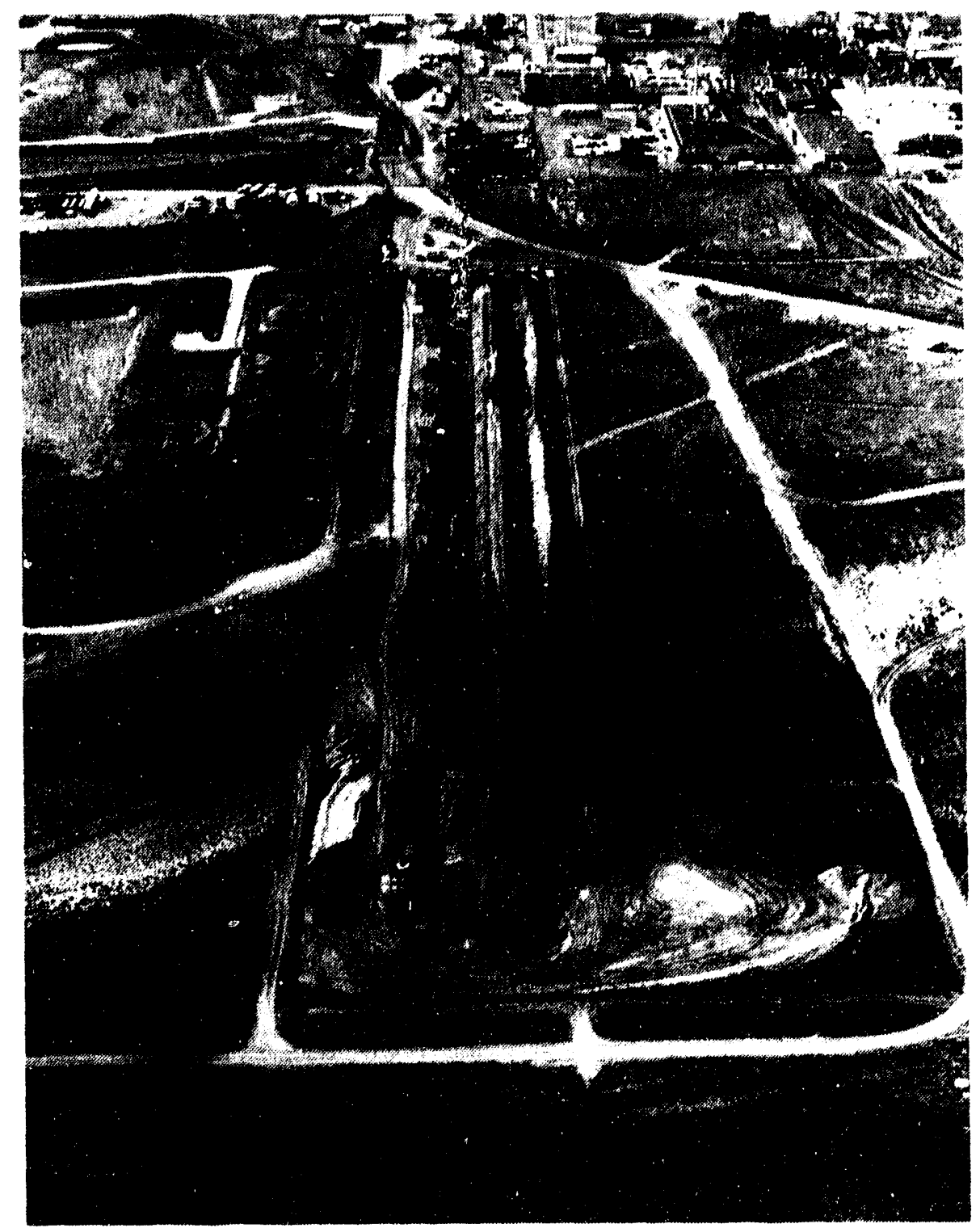

The East and West Process Trenches, stretching north of the 300 Area in 1991. 


\section{Solid Waste Disposals}

Throughout the early years of 300 Area operations, at least six solid waste burial grounds were located therein. The first one, now designated Burial Ground 618-8, was located about 750 yards north of the 300 Area beneath the site of the current 300 Area North Parking Lot and was actively used during 1943 and 1944. The second was Burial Ground 618-1, active from 1945 to 1951 , which was located just inside the northeast corner of the 300 Area. Burial Ground 618-2, located just north of 618-1 and active from 1951 to 1954 , consisted of four east-west trenches. Most of the contents in this burial ground were destroyed by fire on February 17, 1954. A fourth waste burial site, Burial Ground 618-3, located just west of Burial Ground 618-2, was active from 1954 to 1955 . It filled up quickly because it received the demolition and construction debris, including large equipment parts and structural materials, from the remodeling of the 313, 303-J, and 303-K Buildings and from the construction of the 311 facilities.

\section{Unique Burial Containers}

As high-level radiochemical and radiometallurgical operations got under way in the 325 and 327 Buildings in 1953, solid waste burial practices for the 300 Area began to change. High radiation levels in and near Burial Ground 618-2, generated by 325 and 327 Buildings' wastes, concerned Site monitors. On their recommendation, Burial Ground 618-10, known as "300 North," opened in 1954 about 4.3 miles northwest of the 300 Area. Until it was phased out of operation between 1962 and 1964, this burial ground consisted of trenches and rows of burial caissons known as "pipe fields." The caissons were made of 5 to 6 open-bottomed 55-gallon drums welded together and buried upright. From the mid-1950s until about 1960 , solid radioactive wastes were collected from operations buildings in cardboard containers and then stored in lead pans known as "gunk catchers" and transported to 300 North in shielded "load luggers." The cardboard waste containers then were dropped from the gunk catchers down the caissons, and the hole was filled with sand and dirt until radiation levels declined to a safe or "tolerance" reading. If radiation levels could not be reduced to tolerance ranges, concrete was poured down the hole until such levels were achieved.

\section{Milk Pails, Grape Juice Cans, and Gatling Guns}

Beginning about 1960 , after waste had become hotter in the 325 and 327 Buildings, cardboard waste containers and gunk catchers were replaced by the milk pail disposal system. Radioactive wastes were collected in the operations buildings in 5- to 6-gallon aluminum milk pails. A commercial gelatin was poured in to seal the top, and each milk pail then was placed in an individual cask containing lead shielding surrounded by an aluminum shell. These casks were transported to 300 North and, after 1962 , to the Wye Burial Ground where the milk pails (not the casks) were disposed of in the buried caissons and covered with sand or concrete. The Wye Burial Ground (also known as 618-11) was active from 1962 to 1970 and was located about 6 miles north of the 300 Area near the present site of the Washington Public Power Supply System reactor No. 2. The 300 North and Wye Burial Grounds also received 1-quart "grape juice cans" that held used, highly radioactive charcoal filters from the operations buildings. Grape juice cans were transported in cylindrical, shielded casks known as "Gatling Gun Casks." 


\section{Paint Cans and Lard Cans}

During 1966 and 1967 solid waste disposal caissons and containers used for 300 Area disposals changed in two ways. A new type of caisson (sometimes called a "silo") with its top opening angled at $\mathbf{4 5}$ degrees to give better radiation shielding to disposal workers was designed and fabricated at Hanford. At the same time, the milk pail system was replaced by the paint can system. Radioactive wastes from operations buildings were collected in one-gallon paint cans with metal lids fastened on by two sets of clips. Eight paint cans together fit into a new cylindrical cask with lead shielding surrounded by a stainless steel shell. Thus, more securely sealed and heavily shielded solid wastes traveled to the Wye Burial Grounds and, after 1970, to 200 Areas Burial Grounds. The casks themselves were not disposed of but were reused many times. The paint can system continued in use for many years and is still used to some extent today. Recently, however, the system has been augmented by the use of 50-pound "lard cans." These 10-gallon containers are used for high-activity solid radioactive wastes generated in 300 Area structures.

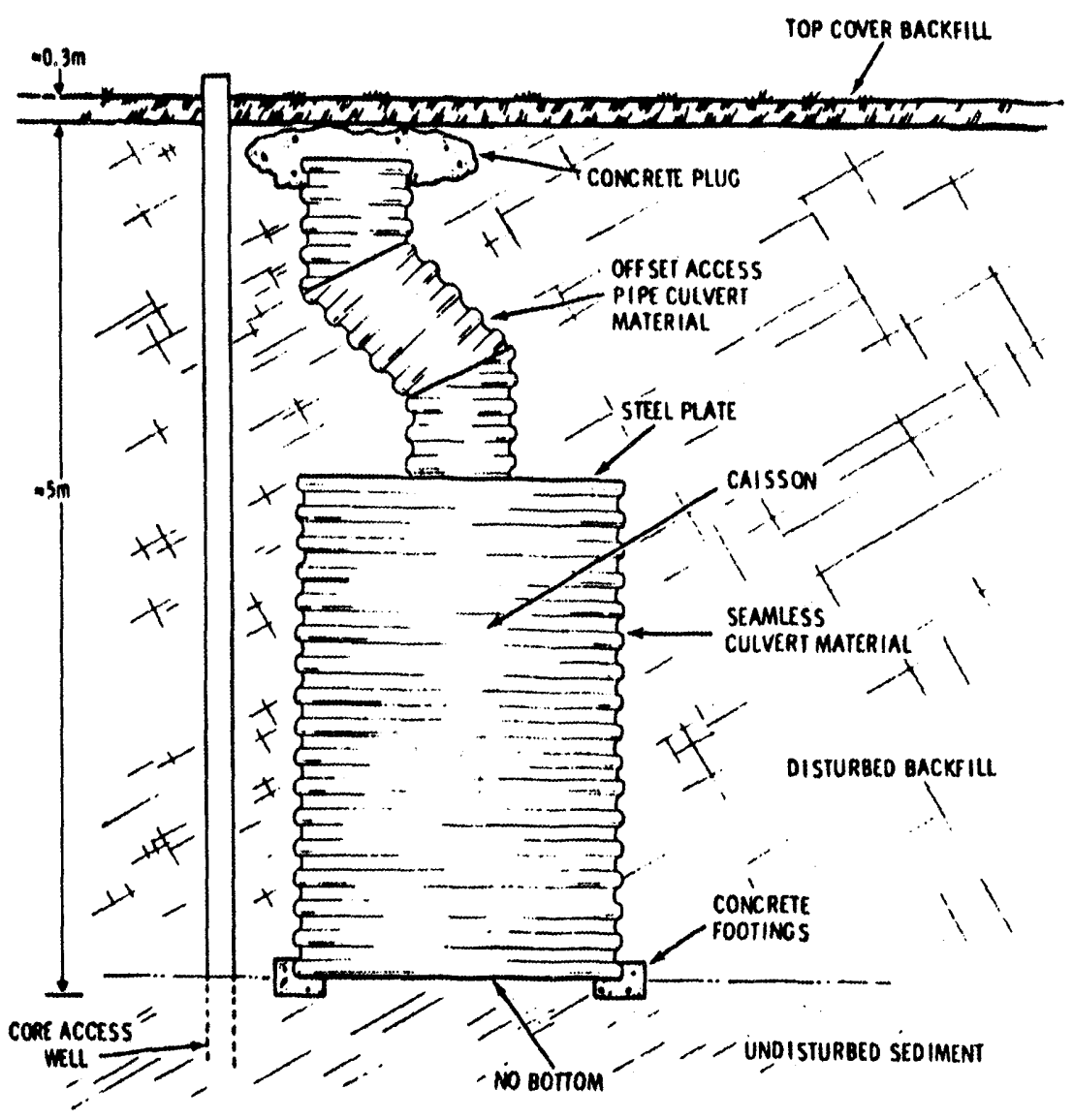

Undergound waste storage caisson, typical of those used in Hanford's burial grounds beginning in about 1966, had an angled opening to protect disposal workers from exposure to radiation. 


\section{WHC-MR-0440}

During the early and middle years of 300 Area operations some other solid waste disposal sites were used on both a planned and inadvertent basis. In 1954 approximately 5,000 gallons of drummed solvent wastes (primarily UNH and hexone) from 321 Building tests were buried about 0.5 miles due west of the 300 Area north perimeter fence. Additionally, many sites to the northwest of the 300 Area along the railroad tracks leading to the 300 Area received aboveground deposits of uranium-contaminated aluminum and aluminum-silicon turnings. The rail loading spot for solid scrap, about 1 mile northwest of the 313 Building, received the most concentrated deposits. However, spills of uranium-contaminated aluminum and aluminum-silicon occurred along the intervening length of track; as well as along vehicle roads; on the surfaces of burial grounds throughout and north of this region; and especially near the 300 West Quonset Hut, a small station from which rail loadings were recorded and tracked. Another contaminated waste disposal site was located just west of the 300 Area West Gate along the highway. There, until the late 1960s, used resins from ion-exchange columns in the $\mathbf{3 2 5}$ and $\mathbf{3 2 4}$ Buildings were disposed of aboveground in 30-gallon cardboard drums known as "paper drums." Over months and years, these paper drums disintegrated, and their contents decomposed into the soil.

\section{Was Year of Change}

In 1970 all of the principal operating contractors of the Hanford Site joined together to conduct a study of solid waste disposal practices. They recommended segregation and labeling of several waste types, including transuranic waste and wastes containing asbestos, polychlorinated biphenyls (PCBs), radioactive animal carcasses, and many other categories. They also recommended strict waste minimization practices (because burial grounds all around HW were filling and engaging more space), the purging of all liquids from solid wastes scheduled for burial (to prevent underground leaching of radionuclides), and advised that all future burials take place in the 200 Areas. The implementation of the last recommendation resulted in the final closure of the Wye Burial Grounds in 1970 and ended solid waste burials in the $\mathbf{3 0 0}$ Area and vicinity from that time on. 


\section{WHC-MR-0440}

This page intentionally left blank. 


\section{References}

1. Atoms for Peace and War, Hewlett, R. G., and Holl, J. M., 1989, University of California Press, Berkeley, California.

2. Construction of Hanford Engineer Works: History of the Project, HAN-10970, Volume IV, 1945, E. I. duPont de Nemours and Co., Wilmington, Deleware.

3. Manufacturing Process Specifications, WHC-CM-5-20 (formerly DUN-5601), Specification X-303, 1988, Westinghouse Hanford Company, Richland, Washington.
4. Operation of Hanford Engineer Works, HAN-73214, Book 10, 1946, E. I. duPont de Nemours and Co., Wilmington, Deleware.

5. Operation of Hanford Engineer Works, HAN-73214, Book 14, 1946, E. I. duPont de Nemours and Co., Wilmington, Delaware.

6. Proposal for Laboratory Facilities in the Technical Center, HW-14110, 1949, General Electric Hanford Company, Richland, Washington. 
WHC-MR-0440

This page intentionally left blank. 

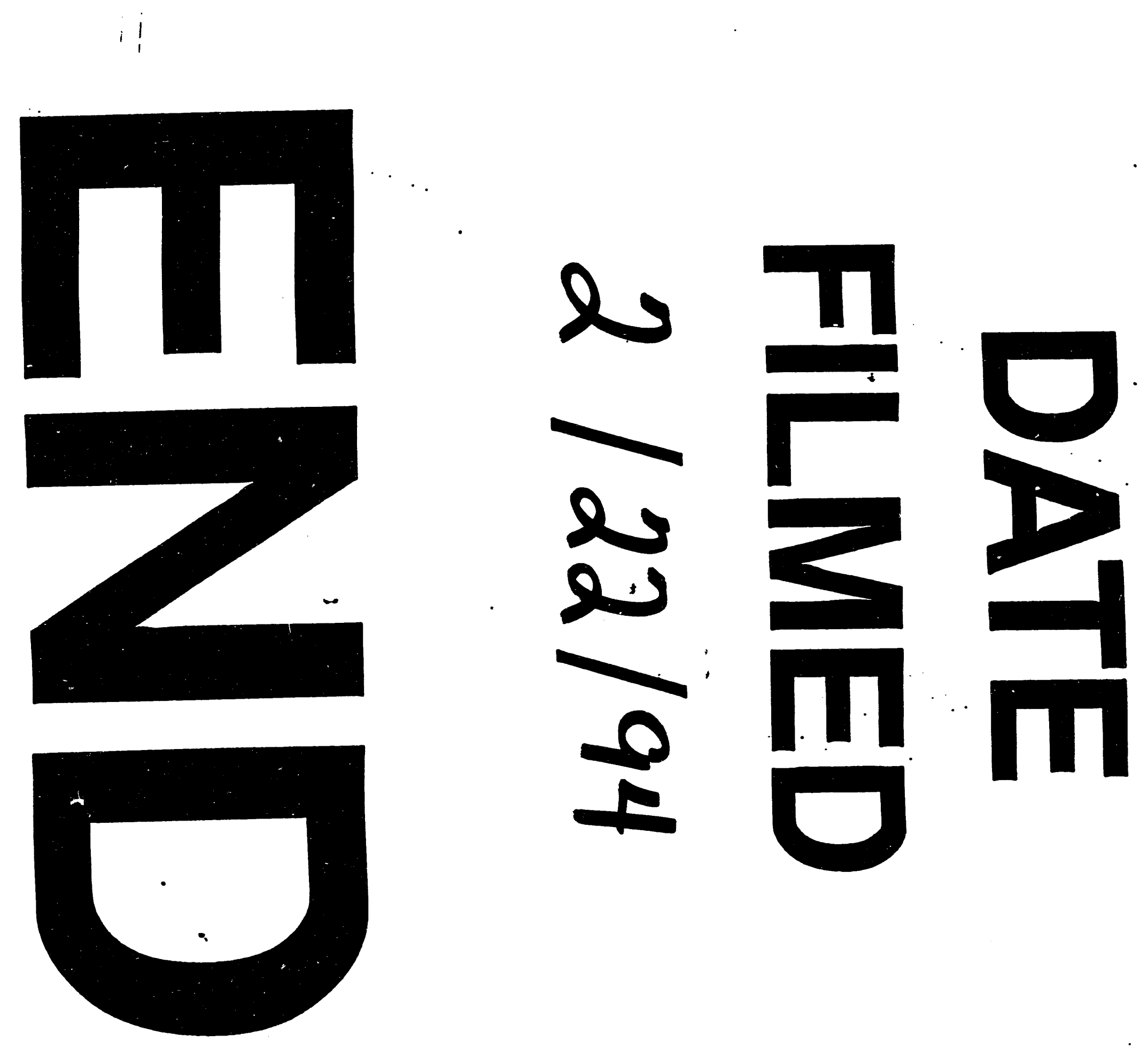
